ENG.20050929.0005

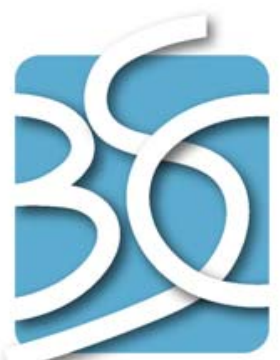

BECHTEL

SAIC COMPANYLC

QA: QA

000-30R-MGR0-00400-000-003

September 2005

\title{
Nuclear Safety Design Bases for License Application
}

Prepared for:

U.S. Department of Energy

Office of Civilian Radioactive Waste Management

Office of Repository Development

1551 Hillshire Drive

Las Vegas, Nevada 89134-6321

Prepared by:

Bechtel SAIC Company, LLC

1180 Town Center Drive

Las Vegas, Nevada 89144

Under Contract Number

DE-AC28-01RW12101 


\section{DISCLAIMER}

This report was prepared as an account of work sponsored by an agency of the United States Government. Neither the United States Government nor any agency thereof, nor any of their employees, nor any of their contractors, subcontractors or their employees, makes any warranty, express or implied, or assumes any legal liability or responsibility for the accuracy, completeness, or any third party's use or the results of such use of any information, apparatus, product, or process disclosed, or represents that its use would not infringe privately owned rights. Reference herein to any specific commercial product, process, or service by trade name, trademark, manufacturer, or otherwise, does not necessarily constitute or imply its endorsement, recommendation, or favoring by the United States Government or any agency thereof or its contractors or subcontractors. The views and opinions of authors expressed herein do not necessarily state or reflect those of the United States Government or any agency thereof. 
Nuclear Safety Design Bases for License Application

Originator:

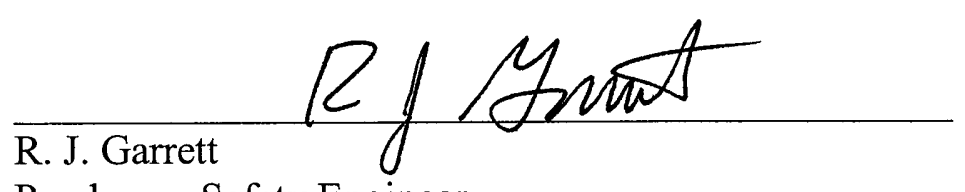

Preclosure Safety Engineer

Checker:

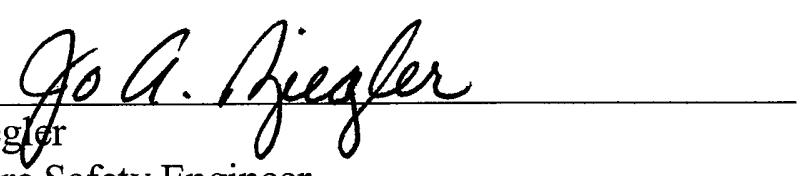

Preclosure Safety Engineer

Responsible Manager:

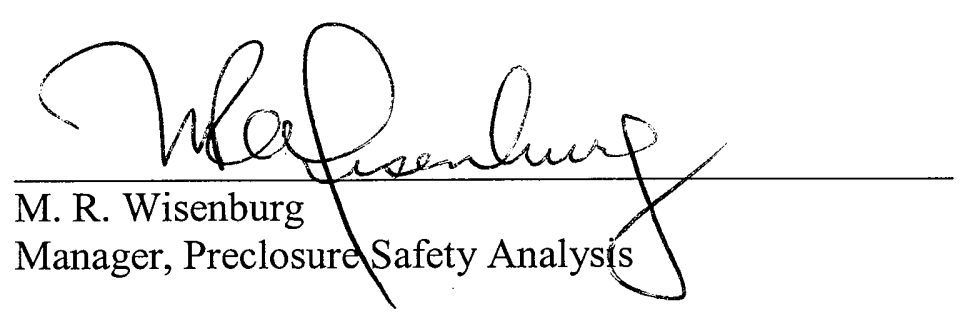

$0 q-2 q-05$

Date

$\frac{9 / 29 / 05}{\text { Date }}$

Date

000-30R-MGR0-00400-000-003

iii

September 2005 


\section{INTENTIONALLY LEFT BLANK}




\section{CHANGE HISTORY}

\begin{tabular}{|c|c|c|c|}
\hline $\begin{array}{l}\text { Revision } \\
\text { Number } \\
\end{array}$ & $\begin{array}{l}\text { Interim } \\
\text { Change No. }\end{array}$ & $\begin{array}{l}\text { Effective } \\
\text { Date }\end{array}$ & Description of Change \\
\hline 00 & N/A & N/A & $\begin{array}{l}\text { Initial issue as } 000-30 R-M G R 0-00400-000-000 \text {. This } \\
\text { initial issue supersedes TDR-MGR-RL-000006. The } \\
\text { document identifier was changed to conform to the } \\
\text { document numbering methodology for engineering } \\
\text { documents. This document is a complete revision of } \\
\text { TDR-MGR-RL-000006. }\end{array}$ \\
\hline 01 & N/A & N/A & $\begin{array}{l}\text { Complete revision to incorporate design changes to } \\
\text { the existing repository design. These design changes } \\
\text { resulted in additions and deletions to the list of } \\
\text { structures, systems, and components classified as } \\
\text { important to safety. These structures, systems, and } \\
\text { components that are important to safety require } \\
\text { nuclear safety design bases or changes to the existing } \\
\text { design bases. }\end{array}$ \\
\hline 02 & N/A & N/A & $\begin{array}{l}\text { Revision to include updated design information. } \\
\text { These design changes resulted in technical changes } \\
\text { and editorial changes to the list of structures, systems, } \\
\text { and components classified as important to safety. } \\
\text { These structures, systems, and components that are } \\
\text { important to safety require nuclear safety design } \\
\text { bases or changes to the existing design bases. The } \\
\text { technical and reference changes are indicated with } \\
\text { change bars. }\end{array}$ \\
\hline 03 & N/A & N/A & $\begin{array}{l}\text { Revision to incorporate comment responses from the } \\
\text { DOE AP-7.5Q acceptance review. Technical changes } \\
\text { are indicated by change bars in margins; minor } \\
\text { editorial changes made are not indicated by change } \\
\text { bars. Supersedes } 000-30 R-M G R 0-00400-000-002 \text {. }\end{array}$ \\
\hline
\end{tabular}




\section{INTENTIONALLY LEFT BLANK}




\section{CONTENTS}

Page

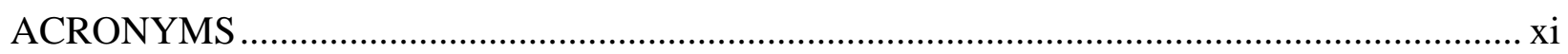

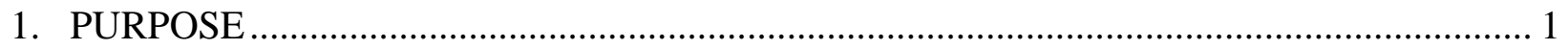

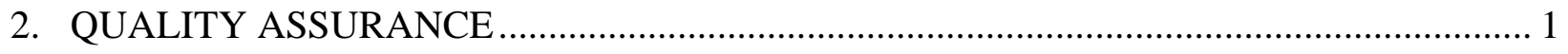

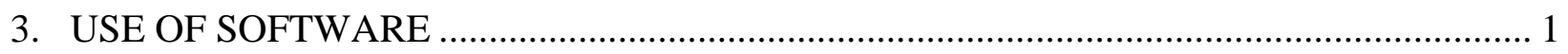

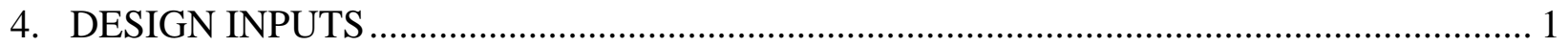

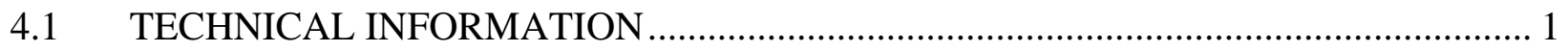

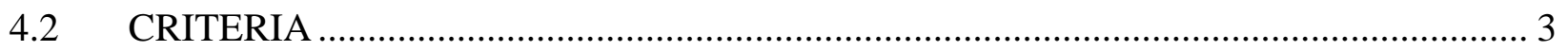

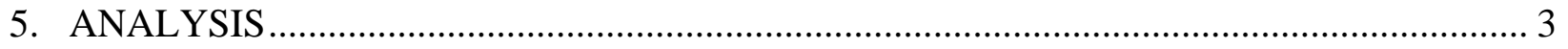

5.1 METHOD ……………………………….................................................... 3

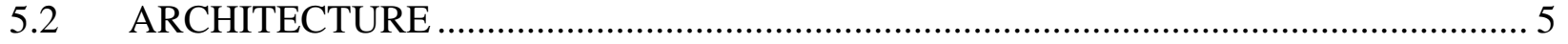

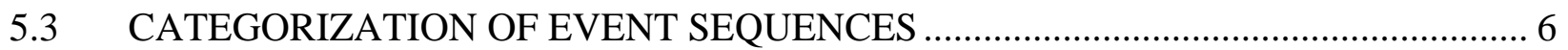

5.4 CLASSIFICATION OF STRUCTURES, SYSTEMS, AND COMPONENTS.................. 7

5.5 EVENT SEQUENCE Consequence ANALYSIS …………............................................ 7

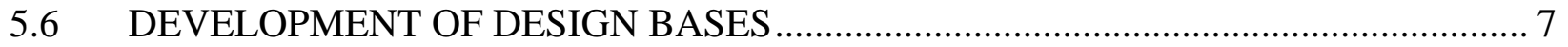

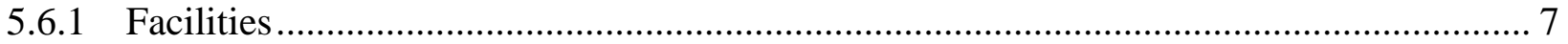

5.6.1.1 Balance of Plant Facility …………………………………………... 8

5.6.1.2 Canister Handling Facility................................................................... 8

5.6.1.3 Dry Transfer Facility ..................................................................... 8

5.6.1.4 Fuel Handling Facility ....................................................................... 8

5.6.1.5 Subsurface Facility …………………………............................. 9

5.6.1.6 Transportation Cask Receipt/Return Facility ...................................... 10

5.6.1.7 Warehouse and Non-Nuclear Receipt Facility ................................... 11

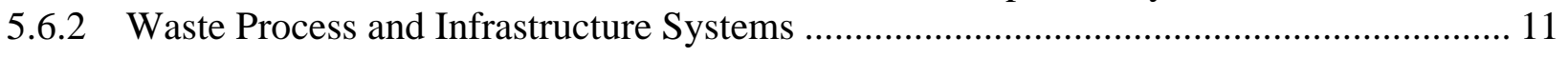

5.6.2.1 Cask/MSC/WP Preparation System .................................................... 11

5.6.2.2 Cask Receipt and Return System ..................................................... 11

5.6.2.3 Communications System ................................................................ 11

5.6.2.4 Digital Control and Management Information System ....................... 12

5.6.2.5 DOE and Commercial Waste Package System ................................... 12

5.6.2.6 Electrical Power System..................................................................... 12

5.6.2.7 Electrical Support System ................................................................ 12

5.6.2.8 Emplacement and Retrieval System................................................... 13

5.6.2.9 Environmental/Meteorological Monitoring System............................ 13

5.6.2.10 Fire Protection System ……………………….................................. 13

5.6.2.11 HVAC Plant Heating and Cooling System ......................................... 13

5.6.2.12 Low-Level Radioactive Waste Generating System............................. 14

5.6.2.13 Low-Level Radioactive Waste Management System.......................... 14

5.6.2.14 Naval Waste Package System ……………………………………...... 14

5.6.2.15 Non-Nuclear Handling System .......................................................... 14 


\section{CONTENTS (Continued)}

Page

5.6.2.16 Non-Radiological Waste Management System............................. 15

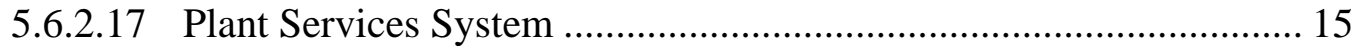

5.6.2.18 Radiation/Radiological Monitoring System.................................. 15

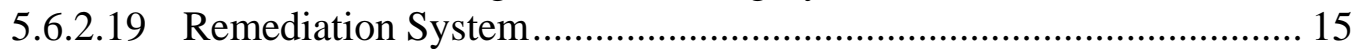

5.6.2.20 Safeguards and Security System ............................................... 15

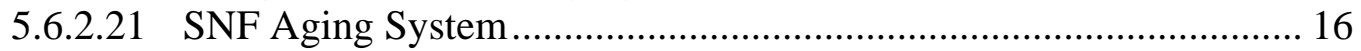

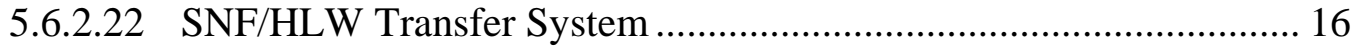

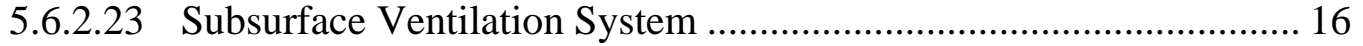

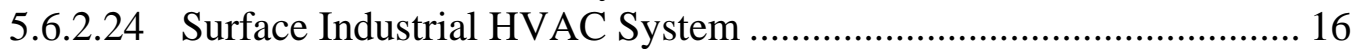

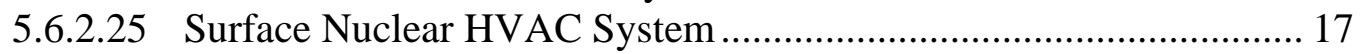

5.6.2.26 Waste Package Closure System ................................................... 17

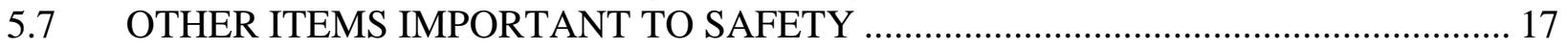

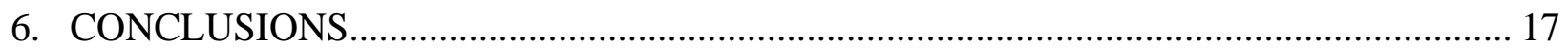

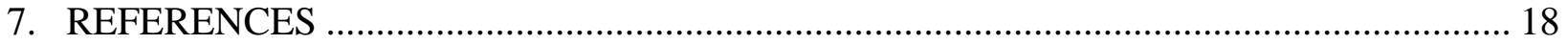

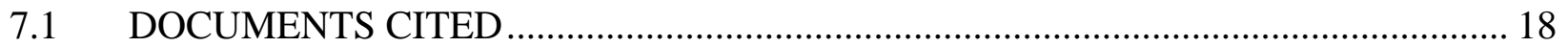

7.2 CODES, STANDARDS, AND REGULATIONS .................................................. 19

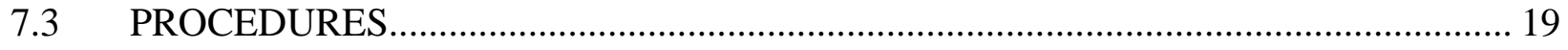

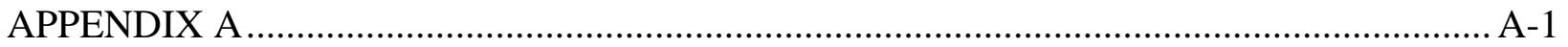

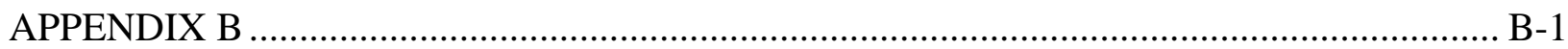

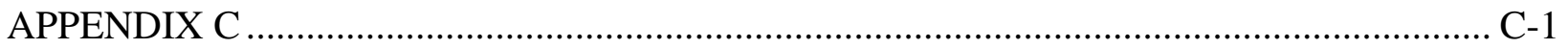




\section{TABLES}

Page

A-I. Nuclear Safety Design Bases of Facilities ....

A-1

A-II. Nuclear Safety Design Bases of Systems and Subsystems...... A-13

C-I. Lift Height Limits ................................................................................................. C-1 


\section{INTENTIONALLY LEFT BLANK}




\section{ACRONYMS}

CHF Canister Handling Facility

DOE U.S. Department of Energy

DPC dual-purpose canister

DTF Dry Transfer Facility

FHF Fuel Handling Facility

HEPA high-efficiency particulate air

HLW high-level radioactive waste

HVAC heating, ventilation, and air-conditioning

ITS important to safety

ITWI important to waste isolation

MCO multicanister overpack

MSC monitored geologic repository site-specific cask

SC safety category

SNF spent nuclear fuel

SSC structure, system, or component

SSCs structures, systems, and components

TCRRF Transportation Cask Receipt/Return Facility

WNNRF Warehouse and Non-Nuclear Receipt Facility

WP waste package 
INTENTIONALLY LEFT BLANK 


\section{PURPOSE}

The purpose of this report is to identify and document the nuclear safety design requirements that are specific to structures, systems, and components (SSCs) of the repository that are important to safety (ITS) during the preclosure period and to support the preclosure safety analysis and the license application for the high-level radioactive waste (HLW) repository at Yucca Mountain, Nevada. The scope of this report includes the assignment of nuclear safety design requirements to SSCs that are ITS and does not include the assignment of design requirements to SSCs or natural or engineered barriers that are important to waste isolation (ITWI).

These requirements are used as input for the design of the SSCs that are ITS such that the preclosure performance objectives of 10 CFR 63.111(b) [DIRS 173273] are met. The natural or engineered barriers that are important to meeting the postclosure performance objectives of 10 CFR 63.113(b) and (c) [DIRS 173273] are identified as ITWI. Although a structure, system, or component (SSC) that is ITS may also be ITWI, this report is only concerned with providing the nuclear safety requirements for SSCs that are ITS to prevent or mitigate event sequences during the repository preclosure period.

\section{QUALITY ASSURANCE}

As established using information presented in Section 2 of Quality Assurance Requirements and Description (DOE 2004 [DIRS 171539]), this report is subject to quality assurance program requirements because the design bases that are identified are applicable to items classified as ITS as defined by 10 CFR 63.2 [DIRS 173273]. This report was developed in accordance with procedures LP-3.11Q-BSC, Technical Reports and LP-3.13Q-BSC, Design Control. Input data are identified and tracked in accordance with LP-3.15Q-BSC, Managing Technical Product Inputs.

\section{USE OF SOFTWARE}

No software required to be qualified under LP-SI.11Q-BSC, Software Management, was used for any part of this analysis. The text of this report is printed using Microsoft Word and is exempted from the requirements of LP-SI.11Q-BSC per Section 2.1.1 of the procedure.

\section{DESIGN INPUTS}

\subsection{TECHNICAL INFORMATION}

4.1.1. In this analysis the acronym for the Dry Transfer Facility (DTF) represents both DTF 1 and DTF 2 and implies that the same systems and components are located within both DTF 1 and DTF 2. Basis: Two identical DTFs are planned. Initially, only one will be constructed and operated. Throughput requirements will determine the timing of construction and operation of the second DTF (BSC 2005e [DIRS 174255], Section 1.1).

4.1.2 Safety Classification of SSCs and Barriers (BSC 2005a [DIRS 174836], Attachment A) establishes the safety classification of the SSCs that are ITS. Basis: This input is 
appropriate for use because it represents the latest safety classification information available for this report.

4.1.3 Categorization of Event Sequences for License Application (BSC 2005b [DIRS 174467], Section 7) establishes the categorization (as Category 1, Category 2, or Beyond Category 2) of the internal and external event sequences that may occur before permanent closure of the repository at Yucca Mountain. Basis: This input is appropriate for use because it represents the latest event sequence categorization information available for this report.

4.1.4 Preclosure Consequence Analyses for License Application (BSC 2005c [DIRS 174261], Sections 6 and 7) identify the functions that are credited for mitigation of a radiological release. Basis: This input is appropriate for use because it provides the consequences of potential event sequences and identifies the SSCs required to mitigate the consequences of event sequences in order to comply with the performance objectives of 10 CFR 63.111(b) [DIRS 173273].

4.1.5 Fire-Induced Event Sequence Analysis (BSC 2005g [DIRS 174263], Section 7) describes the SSCs relied upon for prevention or mitigation of identified fire-induced event sequences. Basis: This input is appropriate for use because it provides the basis for design requirements that are required to mitigate the consequences of fire-induced event sequences in order to comply with the performance objectives of 10 CFR 63.111(b) [DIRS 173273].

4.1.6 Extreme Wind/Tornado/Tornado Missile Hazard Analysis (BSC 2005h [DIRS 174429], Section 9) describes the SSCs relied upon for prevention or mitigation of identified event sequences. Basis: This input is appropriate for use because it provides the basis for design requirements that are required to mitigate the consequences of event sequences associated with extreme winds, tornadoes, and tornado missile hazards in order to comply with the performance objectives of 10 CFR 63.111(b) [DIRS 173273].

4.1.7 Monitored Geologic Repository External Events Hazards Screening Analysis (BSC 2005d [DIRS 174235], Section 6) describes the SSCs relied upon for prevention or mitigation of identified event sequences. Basis: This input is appropriate for use because it provides the basis for design requirements that are required to mitigate the consequences of event sequences associated with external events in order to comply with the performance objectives of 10 CFR 63.111(b) [DIRS 173273].

4.1.8 Reliability Analysis of the Electrical Power Distribution System to Selected Portions of the Nuclear HVAC System (BSC 2004c [DIRS 171490], Table 9) describes the SSCs relied upon for prevention or mitigation of identified event sequences. Basis: This input is appropriate for use because it provides the basis for the design requirements that are required to prevent or mitigate the consequences of event sequences associated with the electrical power system in order to comply with the performance objectives of 10 CFR 63.111(b) [DIRS 173273]. 
4.1.9 Seismic Analysis for Preclosure Safety (BSC 2004a [DIRS 171470], Section 4) describes the functions of SSCs relied upon for prevention or mitigation of identified event sequences. Basis: This input is appropriate for use because it provides the basis for the design requirements that are required to prevent or mitigate the consequences of event sequences associated with seismic events in order to comply with the performance objectives of 10 CFR 63.111(b) [DIRS 173273].

4.1.10 System architecture is established by "Facility, Equipment and System Names for Use in the SAR" (Lucas 2004 [DIRS 170073], Attachments 8 and 9). Basis: This input is appropriate for use because it represents the latest design information and system architecture available for the repository.

4.1.11 Although the Remediation Facility is listed separately in the system architecture provided in Lucas (2004 [DIRS 170073], Attachments 8 and 9), it now included as an integral part of the DTF and will not exist as a separate facility. Basis: The Remediation Facility is integrated within the DTF and provides the space, layout, structures, and embedded systems needed to recover from off-normal conditions during waste-handling operations (e.g., a damaged transportation cask, fuel form, or waste package [WP]) (BSC 2005e [DIRS 174255], Section 1.1).

\subsection{CRITERIA}

\section{Federal Regulations}

The safety classification criteria used in this report are those provided in 10 CFR 63.2 [DIRS 173273] for important to safety. Transportation casks received at the repository comply with requirements of 10 CFR 71.55 [DIRS 173375], which states that casks are to be subcritical even with most reactive credible configuration of fissile material and moderation to the most reactive credible extent, and the design bases of 10 CFR 71.73 [DIRS 173375]. Event sequence categorization methodology is based on the 10 CFR 63.2 definition of event sequence.

\section{ANALYSIS}

\subsection{METHOD}

A distinction is made between the repository design bases and the 10 CFR 63.2 [DIRS 173273] design bases for SSCs that are ITS. All SSCs have design bases; however, only SSCs that are ITS have design bases as defined by 10 CFR 63.2. These 10 CFR 63.2 design bases are required, pursuant to 10 CFR 63.112 [DIRS 173273], to be included in the preclosure safety analysis of the license application for a repository at Yucca Mountain.

The preclosure safety analysis of the license application provides a safety assessment of the 10 CFR 63.2 repository design bases. The 10 CFR 63.2 design bases and the supporting design information are subjected to design control and the other quality assurance criteria of 10 CFR 63.142 [DIRS 173273].

The methodology for developing the 10 CFR 63.2 design bases are summarized in the following paragraphs. 
The Category 1, Category 2, and Beyond Category 2 event sequences derived from the internal, external, and other applicable hazards analyses (such as fire hazards analysis, extreme wind/tornado wind/tornado missile hazard analysis, etc.) are identified. The list of Category 1, Category 2, and Beyond Category 2 event sequences forms a part of the repository licensing bases and appears in the license application. Each Category 1, Category 2, and Beyond Category 2 event sequence involves SSCs that are evaluated within the preclosure safety analysis to assess the likelihood and consequences of an event sequence leading to a dose that exceeds the 10 CFR 63.111(b) [DIRS 173273] preclosure performance objectives. These SSCs may change as the design matures. Changes in the list of event sequences result in a reassessment of affected SSCs and associated 10 CFR 63.2 design bases. Design iterations, design improvements, or design modifications could potentially lead to changes in the list of event sequences and associated SSCs throughout the licensing process and beyond.

Compliance with the 10 CFR 63.111(b) performance objectives for Category 1 and Category 2 event sequences is significantly different for each category. Category 1 event sequence compliance assessments are based on annual performance requirements that require an aggregation of releases. A Category 2 event sequence compliance assessment is made on a perevent basis. No aggregation of releases is made for Category 2 event sequences. Because of these compliance differences, the design bases for SSCs that are ITS involved in Category 2 event sequences are developed before the design bases associated with the Category 1 event sequences. ITS SSCs may be required to ensure that an event sequence is categorized as Beyond Category 2.

The set of SSCs that has been classified as ITS based on the Category 1 and Category 2 event sequences is identified. In addition, those SSCs credited for ensuring that an event sequence is categorized as Beyond Category 2 are identified. These SSCs that have been classified as ITS require 10 CFR 63.2 design bases to be established.

A single SSC is then chosen from the set of SSCs classified as ITS and the Category 1, Category 2, and Beyond Category 2 event sequences that credit the function of that SSC are identified from the applicable supporting analyses.

For the selected SSC that is ITS, the Category 2 and Beyond Category 210 CFR 63.2 design bases are developed. This selection process is repeated until the SSCs that are ITS have 10 CFR 63.2 design bases developed for each of the Category 2 and Beyond Category 2 event sequences.

After the design bases for the Category 2 and Beyond Category 2 event sequences are identified, an SSC that is ITS for meeting the Category 1 performance objective is selected. The $10 \mathrm{CFR}$ 63.2 design bases for the SSC that is ITS that meet the 10 CFR 63.111(b) preclosure performance objectives for Category 1 event sequences are then selected. This process is repeated until 10 CFR 63.2 design bases are established for the SSCs that are ITS in the Category 1 event sequences. 


\subsection{ARCHITECTURE}

The repository is comprised of the following facilities (Lucas 2004 [DIRS 170073], Attachments 8 and 9):

1. $\quad$ Balance of Plant Facility

2. $\quad$ Canister Handling Facility (CHF)

3. DTF

4. $\quad$ Fuel Handling Facility (FHF)

5. Subsurface Facility

6. Transportation Cask Receipt/Return Facility (TCRRF)

7. Warehouse and Non-Nuclear Receipt Facility (WNNRF).

Although the Remediation Facility is listed separately in the system architecture provided in "Facility, Equipment and System Names for Use in the SAR" (Lucas 2004 [DIRS 170073], Attachments 8 and 9), it has since been included as an integral part of the DTF and does not exist as a separate facility.

Repository systems are subdivided into process systems and infrastructure systems. Process systems include systems that involve primary processes in the waste handling and waste isolation systems while the infrastructure systems are those systems that are needed to provide support to the process systems and the facilities. Process and infrastructure systems exist and operate in multiple facilities.

The repository waste handling systems are evaluated to determine the applicability of Category 1, Category 2, and Beyond Category 2 event sequences associated with preclosure operations (BSC 2005b [DIRS 174467]). The Balance of Plant facilities have no Category 1, Category 2, or Beyond Category 2 event sequences associated with preclosure operations (BSC 2005b [DIRS 174467]). The remaining repository facilities and the repository process systems that are present in these facilities include the following (Lucas 2004 [DIRS 170073], Attachments 8 and 9):

- Transportation Cask Receipt/Return Facility

- Cask Receipt and Return System

- Warehouse and Non-Nuclear Receipt Facility

- DOE and Commercial Waste Package System

- Naval Waste Package System

- Non-Nuclear Handling System

- Dry Transfer Facility

- DOE and Commercial Waste Package System

- Naval Waste Package System

- Cask Receipt and Return System

- Non-Nuclear Handling System

- Cask/MSC/WP Preparation System

- SNF/HLW Transfer System 
- Waste Package Closure System

- Remediation System

- Emplacement and Retrieval System

- SNF Aging System

- Canister Handling Facility

- DOE and Commercial Waste Package System

- Naval Waste Package System

- Cask Receipt and Return System

- Non-Nuclear Handling System

- Cask/MSC/WP Preparation System

- SNF/HLW Transfer System

- Waste Package Closure System

- Emplacement and Retrieval System

- SNF Aging System

- Fuel Handling Facility

- DOE and Commercial Waste Package System

- Naval Waste Package System

- Cask Receipt and Return System

- Non-Nuclear Handling System

- Cask/MSC/WP Preparation System

- SNF/HLW Transfer System

- Waste Package Closure System

- Emplacement and Retrieval System

- SNF Aging System

- Subsurface Facility

- DOE and Commercial Waste Package System

- Naval Waste Package System

- Emplacement and Retrieval System

- SNF Aging System

The applicable repository facility and process system SSCs provided in this report are presented with their corresponding 10 CFR 63.2 design bases.

\subsection{CATEGORIZATION OF EVENT SEQUENCES}

An event sequence is defined by the U.S. Nuclear Regulatory Commission to be "a series of actions and/or occurrences within the natural and engineered components of a geologic repository operations area that could potentially lead to exposure of individuals to radiation" (10 CFR 63.2). Event sequences that are "expected to occur one or more times before permanent closure of the geologic repository operations area are referred to as Category 1 event sequences" (10 CFR 63.2). "Other event sequences that have at least one chance in 10,000 of occurring before permanent closure are referred to as Category 2 event sequences" (10 CFR 63.2). Less likely event sequences are considered Beyond Category 2. An event that has no potential for "exposure of individuals to radiation" is not considered an event sequence. 
The initial step of the process for determining the 10 CFR Part 63.2 design bases involves determining the Category 1, Category 2, and Beyond Category 2 event sequences. These event sequences are identified in the internal, external, and other applicable hazards analyses. Categorization of Event Sequences for License Application (BSC 2005b [DIRS 174467]) establishes the categorization (as Category 1, Category 2, or Beyond Category 2) of the internal and external event sequences that may occur before permanent closure of the repository at Yucca Mountain.

\subsection{CLASSIFICATION OF STRUCTURES, SYSTEMS, AND COMPONENTS}

Safety Classification of SSCs and Barriers (BSC 2005a [DIRS 174836]) establishes the safety classification of the repository SSCs. If an SSC is determined to be ITS or ITWI, then it is classified as safety category (SC). An SSC can be ITS, ITWI, both, or neither. If an SSC is neither ITS nor ITWI, it is classified as Non-SC. The safety classifications of the repository SSCs, as established in Safety Classification of SSCs and Barriers (BSC 2005a [DIRS 174836]), are reproduced in the tables found in Appendix A of this analysis. The set of SSCs that have been classified as ITS based on the Category 1 and Category 2 event sequences, as well as those SSCs credited for ensuring that an event sequence is categorized as Beyond Category 2, are identified.

\subsection{EVENT SEQUENCE CONSEQUENCE ANALYSIS}

The worker and offsite radiation doses were calculated in Preclosure Consequence Analyses for License Application (BSC 2005c [DIRS 174261], Section 7) for the event sequences identified in Categorization of Event Sequences for License Application (BSC 2005b [DIRS 174467], Section 7). In addition, any mitigative functions performed by ITS SSCs that are credited in the dose calculations are identified (such as high-efficiency particulate air [HEPA] filters).

\subsection{DEVELOPMENT OF DESIGN BASES}

The development of the 10 CFR 63.2 design bases follows the methodology described in Section 5.1 using the inputs described in Section 4.1.

The repository facilities, and the repository process systems that are present in these facilities, are listed in the following subsections based on the repository architecture described in Section 5.2. The facilities and systems that have Category 1 or Category 2 event sequences that require SSCs to perform prevention or mitigation functions are identified. In some instances, 10 CFR 63.2 design bases are developed for SSCs that provide prevention functions to ensure that the frequency of an event sequence is Beyond Category 2.

The 10 CFR 63.2 design bases (the nuclear safety design bases) for the repository facilities, systems, subsystems, and selected SSCs that are developed using the methodology described in Section 5.1 are presented in Tables A-I and A-II of Appendix A.

\subsubsection{Facilities}

The facilities include the following: the Balance of Plant Facility, CHF, DTF, FHF, Subsurface Facility, TCRRF, and the WNNRF (Lucas 2004 [DIRS 170073], Attachments 8 and 9). The 
safety categories for these facilities are shown in Attachment A of Safety Classification of SSCs and Barriers (BSC 2005a [DIRS 174836]).

\subsubsection{Balance of Plant Facility}

As established by Categorization of Event Sequences for License Application (BSC 2005b [DIRS 174467], Section 7), there are no Category 1 or Category 2 event sequences that require SSCs in the facilities that comprise the Balance of Plant Facility to perform prevention or mitigation functions. The switchgear facility contains portions of the electrical power system that are ITS. Although the structure contains ITS components, there are no event sequences identified that prevent the ITS components from performing their ITS function. No Balance of Plant facility is required to function to protect an ITS or ITWI SSC or natural or engineered barrier. The safety category of the facility is Non-SC (BSC 2005a [DIRS 174836], Attachment A). There are no nuclear safety design bases associated with the Balance of Plant Facility.

\subsubsection{Canister Handling Facility}

As established by Categorization of Event Sequences for License Application (BSC 2005b [DIRS 174467], Section 7), there are Category 2 event sequences that could occur in this facility and there are features of the facility that are ITS for prevention or mitigation of event sequences. The Seismic Analysis for Preclosure Safety (BSC 2004a [DIRS 171470], Attachment III) has identified potential seismically initiated failures that could lead to undesired consequences. This facility contains SSCs that are ITS; it does not contain SSCs or natural or engineered barriers that are ITWI. The safety category of this facility is SC (BSC 2005a [DIRS 174836], Attachment A). Table A-I in Appendix A presents the nuclear safety design bases associated with the CHF.

\subsubsection{Dry Transfer Facility}

As established by Categorization of Event Sequences for License Application (BSC 2005b [DIRS 174467], Section 7) and Preclosure Consequence Analysis for License Application (BSC 2005c [DIRS 174261], Section 7), there are Category 1 and Category 2 event sequences that could occur in this facility and there are features of the facility that are ITS for prevention or mitigation of event sequences. Seismic Analysis for Preclosure Safety (BSC 2004a [DIRS 171470], Attachment III) has identified potential seismically initiated failures that could lead to undesired consequences. This facility contains SSCs that are ITS; it does not contain SSCs or natural or engineered barriers that are ITWI. The safety category of this facility is SC (BSC 2005a [DIRS 174836], Attachment A). Table A-I in Appendix A presents the nuclear safety design bases associated with the DTF.

\subsubsection{Fuel Handling Facility}

As established by Categorization of Event Sequences for License Application (BSC 2005b [DIRS 174467], Section 7) and the Preclosure Consequence Analysis for License Application (BSC 2005c [DIRS 174261], Section 7), there are Category 1 and Category 2 event sequences that could occur in this facility and there are features of the facility that are ITS for prevention or mitigation of event sequences. The Seismic Analysis for Preclosure Safety (BSC 2004a [DIRS 171470], Attachment III) has identified potential seismically initiated failures that could lead to undesired consequences. This facility contains SSCs that are ITS; it does not contain SSCs or 
natural or engineered barriers that are ITWI. The safety category of this facility is SC (BSC 2005a [DIRS 174836], Attachment A). Table A-I in Appendix A presents the nuclear safety design bases associated with the FHF.

\subsubsection{Subsurface Facility}

The Subsurface Facility provides space for the emplacement, postemplacement, and subsurface development activities. The facility isolates the radioactive material from the environment and monitors the underground area. The Subsurface Facility includes the portals, ramps, access mains and rail, turnouts, emplacement drifts (including the ground support, invert structures and ballast, waste package emplacement pallet, drip shield, and, if used, backfill), exhaust mains, shafts and raises, shaft and raise access drifts, alcoves, and performance confirmation areas. The facility includes the surface structures at the shafts and raises, and closure seals and plugs (BSC 2005a [DIRS 174836], Section 6.3.1.5). The safety category of the Subsurface Facility is SC (BSC 2005a [DIRS 174836], Attachment A).

Components associated with the emplacement activity include the emplacement drift invert, drip shield, drip shield emplacement gantry, emplacement drift, nonemplacement openings, ground support, surface structures at shafts and raises, and waste package emplacement pallets (BSC 2005a [DIRS 174836], Section 6.3.1.5).

Nonemplacement openings used for subsurface waste emplacement transporter routes during the preclosure period, such as portals, ramps, access mains, and turnouts, are ITS because the rock properties and drift layout dimensions are used as input for analysis of rockfalls that could damage a waste package (BSC 2005a [DIRS 174836], Section 6.3.1.5).

During postclosure, the emplacement drifts are part of the upper natural barrier that must be designed and constructed to specification to ensure that thermal hydrologic properties, and layout functions and size, perform consistently with the emplacement drift modeling used in rockfall and drift analyses (BSC 2005a [DIRS 174836], Section 6.3.1.5).

Ground support in emplacement drifts or nonemplacement openings is not considered in rockfall models. The rock blocks predicted are those that fail in an unsupported opening. During the preclosure period this approach leads to a conservative prediction of rock blocks (i.e., more blocks are predicted to fail in the model than would otherwise be supported and remain stable with ground support). During the postclosure period, it is realistic to not include ground support in rockfall models because ground support will degrade and eventually fail. Therefore, ground support is not ITS or ITWI (BSC 2005a [DIRS 174836], Section 6.3.1.5).

During preclosure operations, the waste package emplacement pallet provides structural support to protect the waste package from damage during surface handling operations and emplacement. During the preclosure and postclosure periods, the waste package emplacement pallet prevents the waste package from coming into contact with the emplacement drift invert and, therefore, mitigates direct exposure to moisture in the invert that may induce corrosion of the waste package (BSC 2005a [DIRS 174836], Section 6.3.1.5).

During the postclosure period, the drip shield protects a waste package from rockfall and redirects seepage that flows into the drift, away from the waste package. The drip shield has 
no preclosure function. During the postclosure period, the emplacement drift invert ballast limits diffusive transport of radionuclides out of engineered barriers by maintaining unsaturated conditions under a waste package and by limiting advective and diffusive transport of radionuclides by sorption onto crushed tuff. The emplacement drift invert (steel and ballast) has no ITS preclosure function (BSC 2005a [DIRS 174836], Section 6.3.1.5).

Preclosure functions of the emplacement drift and the waste package emplacement pallet are ITS; postclosure functions of the waste package emplacement pallet, drip shield, emplacement drift invert ballast, and emplacement drift are ITWI. The safety category of the emplacement activity is SC (BSC 2005a [DIRS 174836], Attachment A). There is no Category 1 or Category 2 event sequence that requires SSCs in the emplacement activity to perform prevention or mitigation functions (BSC 2005b [DIRS 174467], Section 7). The Seismic Analysis for Preclosure Safety (BSC 2004a [DIRS 171470], Attachment III) has identified potential seismically initiated failures that could lead to undesired consequences.

The postemplacement activities include closure, performance confirmation, and thermal management. The closure function has no preclosure application; closure of the repository occurs at the end of the preclosure period. The closure function limits the number of WPs impacted by an intrusive igneous event by preventing magma that has entered an emplacement drift via an intersecting dike from flowing into other emplacement drifts because of backfill placed in access mains, exhaust mains, turnouts, and magma bulkheads. Borehole seals and ramps, shaft, and raise seals are not considered further in the total system performance assessment because of low consequence and are not ITWI (BSC 2005a [DIRS 174836], Attachment A). There is no Category 1 or Category 2 event sequence that requires an SSC in the postemplacement activity to perform a preclosure prevention or mitigation function (BSC 2005b [DIRS 174467], Section 7). Closure items in the postemplacement activity perform postclosure prevention or mitigation functions and are ITWI. The postemplacement activity does not include ITS SSCs; it does include ITWI SSCs or natural or engineered barriers. The safety category of the postemplacement activity is SC (BSC 2005a [DIRS 174836], Attachment A).

The subsurface development activities consist of excavation and providing ground support for nonemplacement and emplacement areas, as appropriate. The subsurface development activity is not associated with spent nuclear fuel (SNF) or HLW (BSC 2005a [DIRS 174836], Section 6.3.1.5). There is no Category 1 or Category 2 event sequence that requires an SSC in the subsurface development activity to perform a prevention or mitigation function (BSC 2005b [DIRS 174467], Section 7). Therefore, the subsurface development activity does not include ITS SSCs, or ITWI SSCs or natural or engineered barriers. The safety category of the subsurface development activity is Non-SC (BSC 2005a [DIRS 174836], Attachment A).

The nuclear safety design bases associated with the Subsurface Facility and its subsystems are presented in Table A-I in Appendix A.

\subsubsection{Transportation Cask Receipt/Return Facility}

As established by Categorization of Event Sequences for License Application (BSC 2005b [DIRS 174467], Section 7), Category 2 event sequences could occur in the TCRRF and there are features of the facility that are ITS for prevention or mitigation of event sequences. The Seismic 
Analysis for Preclosure Safety (BSC 2004a [DIRS 171470], Attachment III) has identified potential seismically initiated failures that could lead to undesired consequences. This facility contains SSCs that are ITS; it does not contain SSCs or natural or engineered barriers that are ITWI. The safety category of this facility is SC (BSC 2005a [DIRS 174836], Attachment A). Table A-I in Appendix A presents the nuclear safety design bases associated with the TCRRF.

\subsubsection{Warehouse and Non-Nuclear Receipt Facility}

As established by Categorization of Event Sequences for License Application (BSC 2005b [DIRS 174467], Section 7), there are no Category 1 or Category 2 event sequences that require SSCs in the WNNRF to perform prevention or mitigation functions. Therefore, this facility consists of no SSCs that are ITS. In addition, there are no natural or engineered barriers that are ITWI. The safety category of this facility is Non-SC (BSC 2005a [DIRS 174836], Attachment A).

\subsubsection{Waste Process and Infrastructure Systems}

\subsubsection{Cask/MSC/WP Preparation System}

As established by Categorization of Event Sequences for License Application (BSC 2005b [DIRS 174467], Section 7), there are Category 2 event sequences that could occur in this system and there are features of the system that are ITS for prevention or mitigation of event sequences. The Seismic Analysis for Preclosure Safety (BSC 2004a [DIRS 171470], Attachment III) has identified potential seismically initiated failures that could lead to undesired consequences. This system contains SSCs that are ITS; it does not contain SSCs or natural or engineered barriers that are ITWI. The safety category of this system is SC (BSC 2005a [DIRS 174836] Attachment A). Table A-II in Appendix A presents the nuclear safety design bases associated with the Cask/MSC/WP Preparation System.

\subsubsection{Cask Receipt and Return System}

As established by Categorization of Event Sequences for License Application (BSC 2005b [DIRS 174467], Section 7), there are Category 2 event sequences that could occur in this system and there are features of the system that are ITS for prevention or mitigation of event sequences. This system consists of SSCs that are ITS; it does not contain SSCs or natural or engineered barriers that are ITWI. The safety category of this system is SC (BSC 2005a [DIRS 174836], Attachment A). Table A-II in Appendix A presents the nuclear safety design bases associated with the Cask Receipt and Return System.

\subsubsection{Communications System}

As established by Categorization of Event Sequences for License Application (BSC 2005b [DIRS 174467], Section 7), there are no Category 1 or Category 2 event sequences that require SSCs in this system to perform prevention or mitigation functions. Therefore, this system consists of no SSCs that are ITS. In addition, there are no natural or engineered barriers that are ITWI. The safety category of this system is Non-SC (BSC 2005a [DIRS 174836], Attachment A). There are no nuclear safety design bases associated with the Communications System. 


\subsubsection{Digital Control and Management Information System}

As established by Categorization of Event Sequences for License Application (BSC 2005b [DIRS 174467], Section 7), there are no Category 1 or Category 2 event sequences that require SSCs in this system to perform prevention or mitigation functions. Therefore, this system consists of no SSCs that are ITS. In addition, there are no natural or engineered barriers that are ITWI. The safety category of this system is Non-SC (BSC 2005a [DIRS 174836], Attachment A). There are no nuclear safety design bases associated with the Digital Control and Management Information System.

\subsubsection{DOE and Commercial Waste Package System}

As established by Categorization of Event Sequences for License Application (BSC 2005b [DIRS 174467], Section 7), a Category 2 event sequence that requires the WP to perform prevention or mitigation functions could occur (BSC 2005b [DIRS 174467], Section 5.1.3). The Seismic Analysis for Preclosure Safety (BSC 2004a [DIRS 171470], Attachment III) has identified potential seismically initiated failures that could lead to undesired consequences. The WP functions during the preclosure and postclosure periods result in the WP being identified as ITS and ITWI, respectively (BSC 2005a [DIRS 174836], Section 6.3.2.5). The safety category of this system is SC (BSC 2005a [DIRS 174836], Attachment A). Table A-II in Appendix A presents the nuclear safety design bases associated with the DOE and Commercial Waste Package System.

\subsubsection{Electrical Power System}

As established by Categorization of Event Sequences for License Application (BSC 2005b [DIRS 174467], Section 7]), there are Category 1 or Category 2 event sequences that require a function or functions of the surface nuclear heating, ventilation, and air-conditioning (HVAC) system for mitigation of Category 1 event sequences (BSC 2005b [DIRS 174467], Section 7). Portions of the switchyard, normal power, and emergency power subsystems are required for operation and support of the surface nuclear HVAC system in the DTF and FHF to maintain doses within the performance objectives of 10 CFR 63.111(b) [DIRS 173273]. The electrical power system supports the availability of the switchyard, normal power, and emergency power to mitigate the consequences of an event sequence. It includes ITS SSCs; it does not include ITWI SSCs or natural or engineered barriers. The safety category of this system is SC (BSC 2005a [DIRS 174836], Attachment A). Table A-II in Appendix A presents the nuclear safety design bases associated with the Electrical Power System.

\subsubsection{Electrical Support System}

As described in Safety Classification of SSCs and Barriers (BSC 2005a [DIRS 174836], Section 6.3.2.7), this system provides electrical support for construction and operation of the surface and subsurface facilities, including ITS functions of the surface nuclear HVAC system. Portions of the cable raceway subsystem that support the availability of electrical power to mitigate the consequences of an event sequence are ITS. SSCs in the remaining portions of the electrical support system do not prevent or mitigate the consequences of a Category 1 or Category 2 event sequence. This system includes ITS SSCs; it does not include ITWI SSCs or 
natural or engineered barriers. The safety category of this system is SC (BSC 2005a [DIRS 174836], Attachment A). Table A-II in Appendix A presents the nuclear safety design bases associated with the Electrical Support System.

\subsubsection{Emplacement and Retrieval System}

As established by Categorization of Event Sequences for License Application (BSC 2005b [DIRS 174467], Section 7), there are Category 2 event sequences that could occur in this system and there are features of the system that are ITS for prevention or mitigation of event sequences. The Seismic Analysis for Preclosure Safety (BSC 2004a [DIRS 171470], Attachment III) has identified potential seismically initiated failures that could lead to undesired consequences. This system contains SSCs that are ITS; it does not contain SSCs or natural or engineered barriers that are ITWI. The safety category of this system is SC (BSC 2005a [DIRS 174836], Attachment A). Table A-II in Appendix A presents the nuclear safety design bases associated with the Emplacement and Retrieval System.

\subsubsection{Environmental/Meteorological Monitoring System}

As established by Categorization of Event Sequences for License Application (BSC 2005b [DIRS 174467], Section 7), there are no Category 1 or Category 2 event sequences that require SSCs in this system to perform prevention or mitigation functions. Therefore, this system consists of no SSCs that are ITS. In addition, there are no natural or engineered barriers that are ITWI. The safety category of this system is Non-SC (BSC 2005a [DIRS 174836], Attachment A). There are no nuclear safety design bases associated with the Environmental/Meteorological Monitoring System.

\subsubsection{Fire Protection System}

This system protects the North Portal area, subsurface emplacement area, and Balance of Plant facilities and consists of the explosion protection subsystem, the fire alarm subsystem, the fire barriers subsystem, the fire detection subsystem, the fire suppression subsystem, and the fire water subsystem (BSC 2005a [DIRS 174836], Section 6.3.2.10).

As established by Categorization of Event Sequences for License Application (BSC 2005b [DIRS 174467], Section 5), to prevent inadvertent criticality in moderator controlled SNF handling areas, portions of the fire suppression subsystem are isolated prior to fissile material entering the area. The manual isolation valves for the double-interlock preaction sprinklers of the fire suppression subsystem located in moderator controlled areas that are relied upon for this purpose are ITS. There are no SSCs associated with the other fire protection subsystems that are ITS. The fire protection system includes ITS SSCs; it does not include ITWI SSCs or natural or engineered barriers. The safety category of this system is SC (BSC 2005a [DIRS 174836], Attachment A). Table A-II in Appendix A presents the nuclear safety design bases associated with the Fire Protection System.

\subsubsection{HVAC Plant Heating and Cooling System}

As established by Categorization of Event Sequences for License Application (BSC 2005b [DIRS 174467], Section 7), there are no Category 1 or Category 2 event sequences that require SSCs in 
this system to perform prevention or mitigation functions. Therefore, this system consists of no SSCs that are ITS. In addition, there are no natural or engineered barriers that are ITWI. The safety category of this system is Non-SC (BSC 2005a [DIRS 174836], Attachment A). There are no nuclear safety design bases associated with the HVAC Plant Heating and Cooling System.

\subsubsection{Low-Level Radioactive Waste Generating System}

As established by Categorization of Event Sequences for License Application (BSC 2005b [DIRS 174467] Section 7), there are no Category 1 or Category 2 event sequences that require SSCs in this system to perform prevention or mitigation functions. Therefore, this system consists of no SSCs that are ITS. In addition, there are no natural or engineered barriers that are ITWI. The safety category of this system is Non-SC (BSC 2005a [DIRS 174836], Attachment A). There are no nuclear safety design bases associated with the Low-Level Radioactive Waste Generating System.

\subsubsection{Low-Level Radioactive Waste Management System}

As established by Categorization of Event Sequences for License Application (BSC 2005b [DIRS 174467], Section 7), there are no Category 1 or Category 2 event sequences that require SSCs in this system to perform prevention or mitigation functions. Therefore, this system consists of no SSCs that are ITS. In addition, there are no natural or engineered barriers that are ITWI. The safety category of this system is Non-SC (BSC 2005a [DIRS 174836], Attachment A). There are no nuclear safety design bases associated with the Low-Level Radioactive Waste Management System.

\subsubsection{Naval Waste Package System}

As established by Categorization of Event Sequences for License Application (BSC 2005b [DIRS 174467], Section 7), a Category 2 event sequence that requires the WP to perform prevention or mitigation functions could occur (BSC 2005b, Section 5.1.3). The Seismic Analysis for Preclosure Safety (BSC 2004a [DIRS 171470], Attachment III) has identified potential seismically initiated failures that could lead to undesired consequences. The WP functions during the preclosure and postclosure periods result in the WP being identified as ITS and ITWI, respectively (BSC 2005a [DIRS 174836], Section 6.3.2.14). The safety category of this system is SC (BSC 2005a [DIRS 174836], Attachment A). Table A-II in Appendix A presents the nuclear safety design bases associated with the Naval Waste Package System.

\subsubsection{Non-Nuclear Handling System}

As established by Categorization of Event Sequences for License Application (BSC 2005b [DIRS 174467], Section 7), there are no Category 1 or Category 2 event sequences that require SSCs in this system to perform prevention or mitigation functions. Therefore, this system consists of no SSCs that are ITS. In addition, there are no natural or engineered barriers that are ITWI. The safety category of this system is Non-SC (BSC 2005a [DIRS 174836], Attachment A). There are no nuclear safety design bases associated with the Non-Nuclear Handling System. 


\subsubsection{Non-Radiological Waste Management System}

As established by Categorization of Event Sequences for License Application (BSC 2005b [DIRS 174467], Section 7), there are no Category 1 or Category 2 event sequences that require SSCs in this system to perform prevention or mitigation functions. Therefore, this system consists of no SSCs that are ITS. In addition, there are no natural or engineered barriers that are ITWI. The safety category of this system is Non-SC (BSC 2005a [DIRS 174836], Attachment A). There are no nuclear safety design bases associated with the Non-Radiological Waste Management System.

\subsubsection{Plant Services System}

As established by Categorization of Event Sequences for License Application (BSC 2005b [DIRS 174467], Section 7), there are no Category 1 or Category 2 event sequences that require SSCs in this system to perform prevention or mitigation functions. Therefore, this system consists of no SSCs that are ITS. In addition, there are no natural or engineered barriers that are ITWI. The safety category of this system is Non-SC (BSC 2005a [DIRS 174836], Attachment A). There are no nuclear safety design bases associated with the Plant Services System.

\subsubsection{Radiation/Radiological Monitoring System}

As established by Categorization of Event Sequences for License Application (BSC 2005b [DIRS 174467], Section 7), there are no Category 1 or Category 2 event sequences that require SSCs in this system to perform prevention or mitigation functions. Therefore, this system consists of no SSCs that are ITS. In addition, there are no natural or engineered barriers that are ITWI. The safety category of this system is Non-SC (BSC 2005a [DIRS 174836], Attachment A). There are no nuclear safety design bases associated with the Radiation/Radiological Monitoring System.

\subsubsection{Remediation System}

As established by Categorization of Event Sequences for License Application (BSC 2005b [DIRS 174467], Section 7), a Category 2 event sequence could occur in this system and there are features of the system that are ITS for prevention or mitigation of event sequences. The Seismic Analysis for Preclosure Safety (BSC 2004a [DIRS 171470], Attachment III) has identified potential seismically initiated failures that could lead to undesired consequences. This system contains SSCs that are ITS; it does not contain SSCs or natural or engineered barriers that are ITWI. The safety category of this system is SC (BSC 2005a [DIRS 174836], Attachment A). Table A-II in Appendix A presents the nuclear safety design bases associated with the Remediation System.

\subsubsection{Safeguards and Security System}

As established by Categorization of Event Sequences for License Application (BSC 2005b [DIRS 174467], Section 7), there are no Category 1 or Category 2 event sequences that require SSCs in this system to perform prevention or mitigation functions. Therefore, this system consists of no SSCs that are ITS. In addition, there are no natural or engineered barriers that are ITWI. The safety category of this system is Non-SC (BSC 2005a [DIRS 174836], Attachment A). There are no nuclear safety design bases associated with the Safeguards and Security System. 


\subsubsection{SNF Aging System}

As established by Categorization of Event Sequences for License Application (BSC 2005b [DIRS 174467], Section 7), a Category 2 event sequence could occur in this system and there are features of the system that are ITS for prevention or mitigation of event sequences. The Seismic Analysis for Preclosure Safety (BSC 2004a [DIRS 171470], Attachment III) has identified potential seismically initiated failures that could lead to undesired consequences. This system contains SSCs that are ITS and contains SSCs or natural or engineered barriers that are ITWI. The safety category of this system is SC (BSC 2005a [DIRS 174836], Attachment A). Table AII in Appendix A presents the nuclear safety design bases associated with the SNF Aging System.

\subsubsection{SNF/HLW Transfer System}

As established by Categorization of Event Sequences for License Application (BSC 2005b [DIRS 174467], Section 7) and Preclosure Consequence Analyses for License Application (BSC 2005c [DIRS 174261], Section 7), there are Category 1 and Category 2 event sequences that require SSCs in this system to perform prevention or mitigation functions. As established by Preclosure Consequence Analyses for License Application (BSC 2005c [DIRS 174261], Section 7), the worker radiation doses and offsite radiation doses for Category 1 and Category 2 event sequences meet the 10 CFR 63.111(b) [DIRS 173273] performance objectives. This system contains SSCs that are ITS; it does not contain SSCs or natural or engineered barriers that are ITWI. The safety category of this system is SC (BSC 2005a [DIRS 174836], Attachment A). Table A-II in Appendix A presents the nuclear safety design bases associated with the SNF/HLW Transfer System.

\subsubsection{Subsurface Ventilation System}

As established by Categorization of Event Sequences for License Application (BSC 2005b [DIRS 174467], Section 7), there are no Category 1 or Category 2 event sequences that require SSCs in this system to perform prevention or mitigation functions. Therefore, this system consists of no SSCs that are ITS. In addition, there are no natural or engineered barriers that are ITWI. The safety category of this system is Non-SC (BSC 2005a [DIRS 174836], Attachment A). There are no nuclear safety design bases associated with the Subsurface Ventilation System.

\subsubsection{Surface Industrial HVAC System}

As established by Categorization of Event Sequences for License Application (BSC 2005b [DIRS 174467], Section 5.1.2.4) there are Category 1 or Category 2 event sequences that require SSCs in this system to perform prevention or mitigation functions. Therefore, this system includes SSCs that are ITS; it does not include ITWI SSCs or natural or engineered barriers. The safety category of this system is SC (BSC 2005a [DIRS 174836], Attachment A). Table A-II in Appendix A presents the nuclear safety design bases associated with the Surface Industrial HVAC System. 


\subsubsection{Surface Nuclear HVAC System}

As established by Categorization of Event Sequences for License Application (BSC 2005b [DIRS 174467], Section 7) and the Preclosure Consequence Analysis for License Application (BSC 2005c [DIRS 174261]), there are Category 1 event sequences that require SSCs in this system to perform prevention or mitigation functions. The Seismic Analysis for Preclosure Safety (BSC 2004a [DIRS 171470], Attachment III) has identified potential seismically initiated failures that could lead to undesired consequences. This system contains SSCs that are ITS; it does not contain SSCs or natural or engineered barriers that are ITWI. The safety category of this system is SC (BSC 2005a [DIRS 174836], Attachment A). Table A-II in Appendix A presents the nuclear safety design bases associated with the Surface Nuclear HVAC System.

\subsubsection{Waste Package Closure System}

As established by Categorization of Event Sequences for License Application (BSC 2005b [DIRS 174467], Section 7), there are no Category 1 or Category 2 event sequences that require SSCs in this system to perform prevention or mitigation functions. Therefore, this system consists of no SSCs that are ITS. In addition, there are no natural or engineered barriers that are ITWI. The safety category of this system is Non-SC (BSC 2005a [DIRS 174836], Attachment A). There are no nuclear safety design bases associated with the Waste Package Closure System.

\subsection{OTHER ITEMS IMPORTANT TO SAFETY}

The transportation casks, standardized U.S. Department of Energy (DOE) SNF disposable canisters, DOE HLW canisters, DOE multicanister overpacks (MCOs), the naval SNF canisters, and the dual-purpose canisters (DPCs) are ITS, but are not a part of the repository architecture (Lucas 2004 [DIRS 170073], Attachments 8 and 9). In the Categorization of Event Sequences for License Application analysis (BSC 2005b [DIRS 174467], Section 7) it was established that a breach of a transportation cask with impact limiters installed is a Beyond Category 2 event sequence based on the 10 CFR 71.55 [DIRS 173375] and 10 CFR 71.73 [DIRS 173375] design requirements for the transportation casks (BSC 2005b [DIRS 174467], Section 7). A breach of a DOE MCO or a standardized DOE SNF canister is a Beyond Category 2 event sequence based on the acceptance requirements of the Waste Acceptance System Requirements Document (DOE 2002 [DIRS 158873], Section 4.3.7). A breach of the DOE HLW canister, naval SNF canister, or DPC as a result of a credible fire is a Beyond Category 2 event sequence (BSC 2005g [DIRS 174263], Section 7).

To ensure that transportation casks with impact limiters installed and that standardized DOE SNF canisters and MCOs are capable of withstanding drops within the design basis without breach, they have been designated as ITS and classified as SC (BSC 2005a [DIRS 174836], Attachment A). Table A-II in Appendix A presents the nuclear safety design bases associated with transportation casks, DOE HLW canisters, DOE MCOs, naval SNF canisters, standardized DOE SNF canisters, and DPCs.

\section{CONCLUSIONS}

The 10 CFR 63.2 design bases (nuclear safety design bases) selected in this report using the methodology presented in Section 5.1 are listed in Appendix A. These nuclear safety design 
bases are used as input to the design of the repository. These output results are reasonable compared to the input and are suitable for their intended use. As the design of the repository proceeds and further event sequences and consequence analyses of hazards are performed, this report will be reviewed for impact and revised as necessary.

\section{REFERENCES}

\subsection{DOCUMENTS CITED}

[DIRS 171470]

BSC (Bechtel SAIC Company) 2004a. Seismic Analysis for Preclosure Safety. 000-00CMGR0-00700-000-00B. Las Vegas, Nevada: Bechtel SAIC Company. ACC:

ENG.20041216.0031.

BSC 2004b. Not used.

[DIRS 171490]

BSC 2004c. Reliability Analysis of the Electrical Power Distribution System to Selected Portions of the Nuclear HVAC System. 100-PSA-EE00-00100-000-00A. Las Vegas, Nevada: Bechtel SAIC Company. ACC: ENG.20041216.0029; ENG.20050812.0005.

BSC 2004d. Not used.

[DIRS 174836]

BSC 2005a. Safety Classification of SSCs and Barriers. 000-00C-MGR0-03000-000. Las

Vegas, Nevada: Bechtel SAIC Company. ACC: ENG.20050805.0004; ENG.20050929.0004.

[DIRS 174467]

BSC 2005b. Categorization of Event Sequences for License Application. 000-00C-MGR000800-000-00C. Las Vegas, Nevada: Bechtel SAIC Company. ACC: ENG.20050808.0003; ENG.20050929.0003.

[DIRS 174261]

BSC 2005c. Preclosure Consequence Analyses for License Application. 000-00C-MGR000900-000-00C. Las Vegas, Nevada: Bechtel SAIC Company. ACC: ENG.20050805.0003; ENG.20050817.0010; ENG.20050825.0023.

[DIRS 174235]

BSC 2005d. Monitored Geologic Repository External Events Hazards Screening Analysis. 00000C-MGR0-00500-000-00B. Las Vegas, Nevada: Bechtel SAIC Company. ACC:

ENG.20050829.0012.

[DIRS 174255]

BSC 2005e. Dry Transfer Facility Description Document. 110-3YD-CD00-00100-000-003. Las Vegas, Nevada: Bechtel SAIC Company. ACC: ENG.20050825.0015. 
[DIRS 174942]

BSC 2005f Project Design Criteria Document. 000-3DR-MGR0-00100-000 REV 005. Las Vegas, Nevada: Bechtel SAIC Company. ACC: ENG.20050826.0001.

[DIRS 174263]

BSC 2005g. Fire-Induced Event Sequence Analysis. 000-00C-MGR0-01300-000-00C. Las Vegas, Nevada: Bechtel SAIC Company. ACC: MOL.20050825.0017.

[DIRS 174429]

BSC 2005h. Extreme Wind/Tornado/Tornado Missile Hazard Analysis. 000-00C-WHS000100-000-00C. Las Vegas, Nevada: Bechtel SAIC Company. ACC: ENG.20050819.0005; ENG.20050926.0007.

[DIRS 158873]

DOE (U.S. Department of Energy) 2002. Waste Acceptance System Requirements Document. DOE/RW-0351, Rev. 4. Washington, D.C.: U.S. Department of Energy, Office of Civilian Radioactive Waste Management. ACC: MOL.20020326.0056.

[DIRS 171539]

DOE 2004. Quality Assurance Requirements and Description. DOE/RW-0333P, Rev. 16. Washington, D.C.: U.S. Department of Energy, Office of Civilian Radioactive Waste Management. ACC: DOC.20040907.0002.

[DIRS 170073]

Lucas, L. 2004. "Facility, Equipment and System Names for Use in the SAR." Interoffice memorandum from L. Lucas (BSC) to M.R. Bryan, June 24, 2004, 0521041674. ACC: MOL.20040625.0028.

\subsection{CODES, STANDARDS, AND REGULATIONS}

[DIRS 173273]

10 CFR 63. 2005 Energy: Disposal of High-Level Radioactive Wastes in a Geologic Repository at Yucca Mountain, Nevada. ACC: MOL.20050405.0118.

[DIRS 173375]

10 CFR 71. 2005 Energy: Packaging and Transportation of Radioactive Material. ACC: MOL.20050523.0022.

\subsection{PROCEDURES}

LP-3.11Q-BSC, Rev. 0, ICN 2. Technical Reports. ACC: DOC.20050215.0009.

LP-3.13Q-BSC, Rev. 1, ICN 0. Design Control. ACC: DOC.20050815.0007.

LP-3.15Q-BSC, Rev. 0, ICN 2. Managing Technical Product Inputs. ACC: DOC.20050801.0010.

LP-SI.11Q-BSC, Rev. 0, ICN 1. Software Management. ACC: DOC.20040015.0008. 
INTENTIONALLY LEFT BLANK 
APPENDIX A

Table A-I. Nuclear Safety Design Bases of Facilities

\begin{tabular}{|c|c|c|c|c}
$\begin{array}{c}\text { Facility, System, or } \\
\text { Subsystem }\end{array}$ & $\begin{array}{c}\text { Component or } \\
\text { Function }\end{array}$ & $\begin{array}{c}\text { ITS or } \\
\text { ITWI }\end{array}$ & $\begin{array}{c}\text { Safety } \\
\text { Category }\end{array}$ & Nuclear Safety Design Bases \\
\hline
\end{tabular}

Balance of Plant Facilities

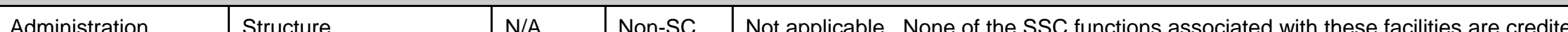
\begin{tabular}{l|l|l} 
Security, Utilities, & for the prevention or mitigation of an event sequence.
\end{tabular}

Emergency

Response, Offsite,

Materials and

Consumables, Fire

Protection,

Maintenance and

Repair, Construction

Support, Central

Control Center, and

Transportation

Facilities

Canister Handling Facility

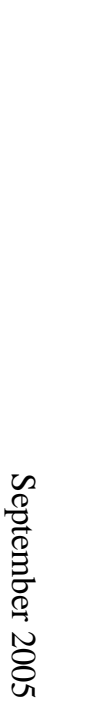

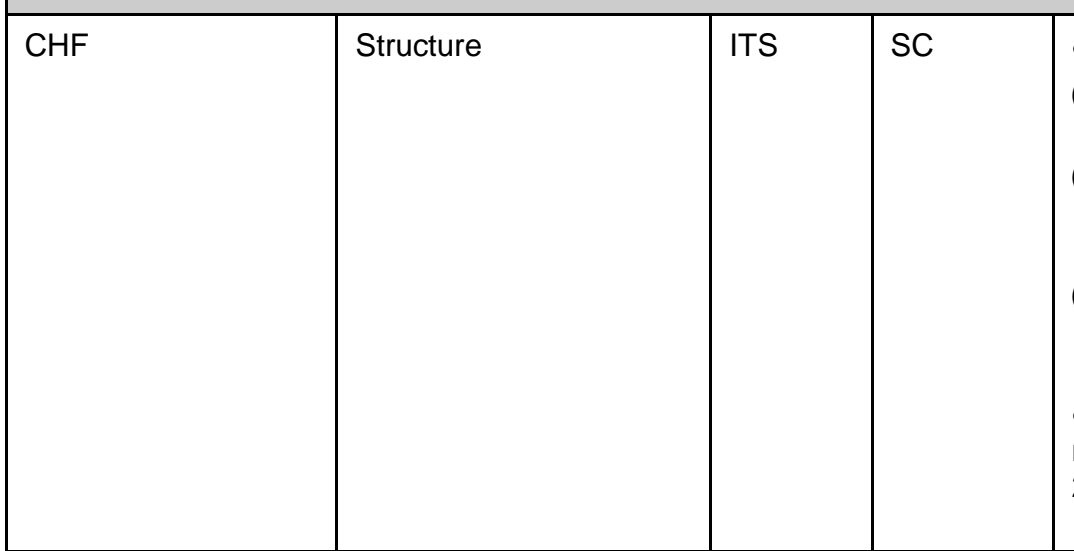

The structure shall:

(1) be designed for the loads associated with a design basis extreme wind speed. (BSC 2005f Section 6.1.1.2 and BSC 2005h Section 9)

(2) be designed for the loads associated with a design basis tornado wind speed with a corresponding pressure drop and rate of pressure drop. (BSC $2005 f$ Section 4.2.2.3.7 and BSC 2005h Section 9)

(3) withstand the local effects of Spectrum II tornado missiles, except for the entrance and exit vestibules and the steel structures on top of the building. (BSC 2005h Sections 6.4.4.1.2 and 9)

- The roof of the structure shall be designed for the loads associated with the maximum observed hourly precipitation event (with a 100-year return period). (BSC 2005f Section 6.1.1.1.2 and BSC 2005b Section 4.3.2) 
Table A-I. Nuclear Safety Design Bases of Facilities

\begin{tabular}{|c|c|c|c|c|}
\hline $\begin{array}{l}\text { Facility, System, or } \\
\text { Subsystem }\end{array}$ & $\begin{array}{l}\text { Component or } \\
\text { Function }\end{array}$ & $\begin{array}{l}\text { ITS or } \\
\text { ITWI }\end{array}$ & $\begin{array}{l}\text { Safety } \\
\text { Category }\end{array}$ & Nuclear Safety Design Bases \\
\hline CHF (continued) & Structure (continued) & ITS & $\mathrm{SC}$ & 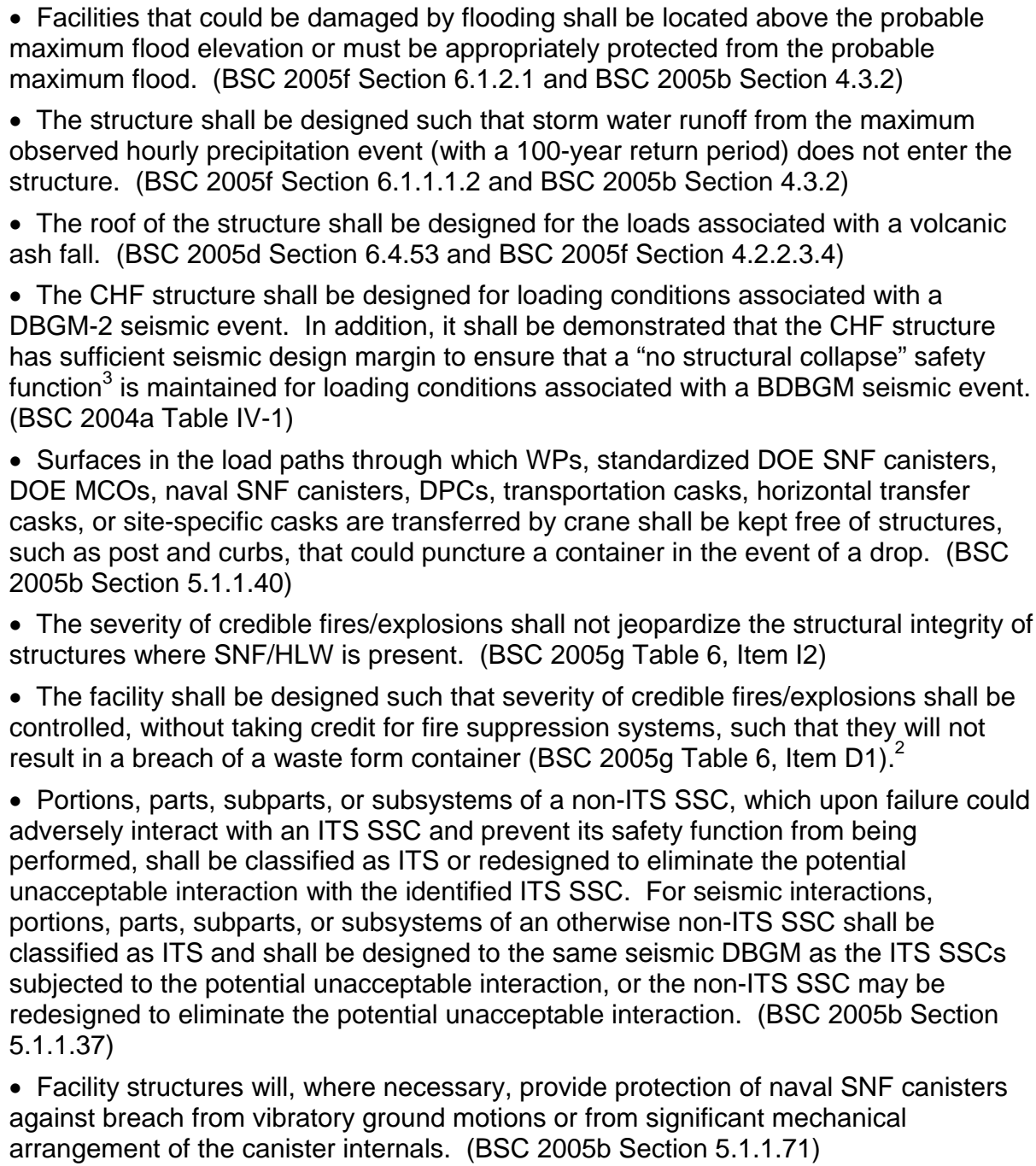 \\
\hline
\end{tabular}


Table A-I. Nuclear Safety Design Bases of Facilities

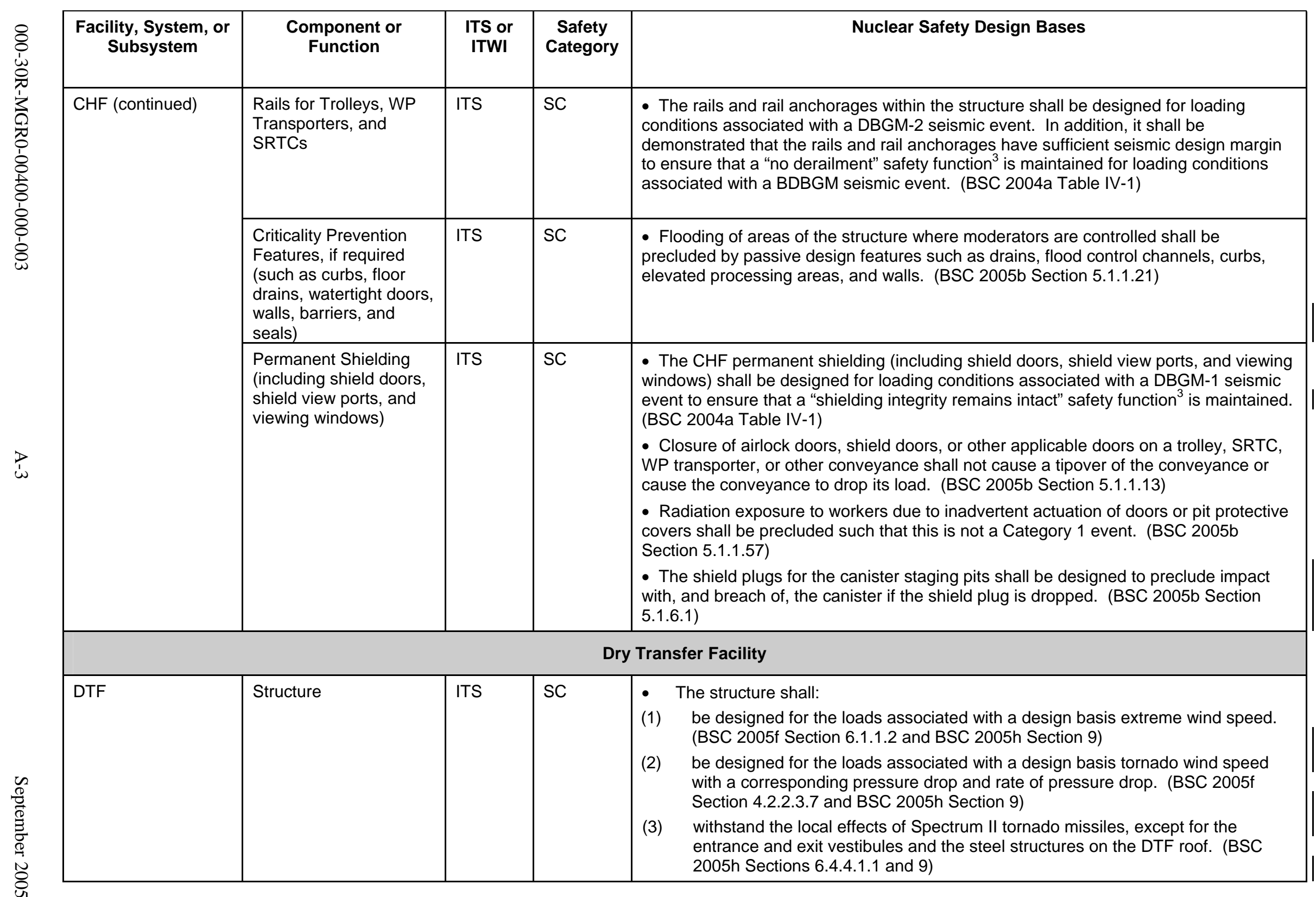


Table A-I. Nuclear Safety Design Bases of Facilities

\begin{tabular}{|c|c|c|c|c|}
\hline $\begin{array}{l}\text { Facility, System, or } \\
\text { Subsystem }\end{array}$ & $\begin{array}{l}\text { Component or } \\
\text { Function }\end{array}$ & $\begin{array}{l}\text { ITS or } \\
\text { ITWI }\end{array}$ & $\begin{array}{l}\text { Safety } \\
\text { Category }\end{array}$ & Nuclear Safety Design Bases \\
\hline DTF (continued) & Structure (continued) & ITS & $\mathrm{SC}$ & 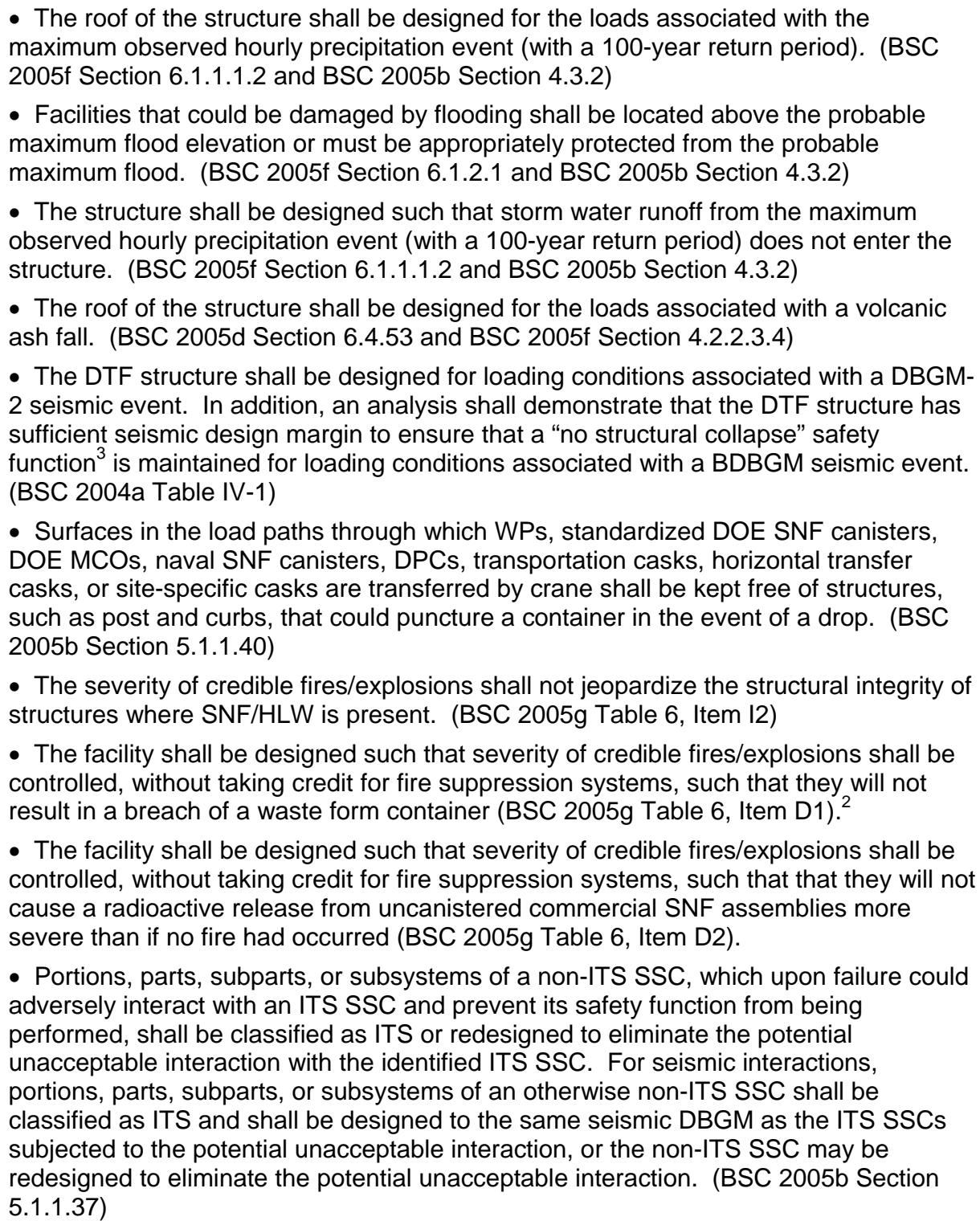 \\
\hline
\end{tabular}


Table A-I. Nuclear Safety Design Bases of Facilities

\begin{tabular}{|c|c|c|c|c|}
\hline $\begin{array}{c}\text { Facility, System, or } \\
\text { Subsystem }\end{array}$ & $\begin{array}{l}\text { Component or } \\
\text { Function }\end{array}$ & $\begin{array}{l}\text { ITS or } \\
\text { ITWI }\end{array}$ & $\begin{array}{l}\text { Safety } \\
\text { Category }\end{array}$ & Nuclear Safety Design Bases \\
\hline \multirow[t]{4}{*}{ DTF (continued) } & Structure (continued) & ITS & SC & $\begin{array}{l}\text { - Facility structures will, where necessary, provide protection of naval SNF canisters } \\
\text { against breach from vibratory ground motions or from significant mechanical } \\
\text { arrangement of the canister internals. (BSC 2005b Section 5.1.1.71) }\end{array}$ \\
\hline & Remediation Pool & ITS & SC & $\begin{array}{l}\text { - The remediation pool structure shall be designed for loading conditions associated } \\
\text { with a DBGM-2 seismic event. In addition, an analysis shall demonstrate that the } \\
\text { remediation pool structure has sufficient seismic design margin to ensure that a "no } \\
\text { failure" safety function is maintained for loading conditions associated with a BDBGM } \\
\text { seismic event. (BSC } 2004 \text { a Table IV-1) } \\
\text { - The remediation pool shall be designed such that there are no penetrations through } \\
\text { that part of the pool structure that is below the minimum water level required for } \\
\text { radiation shielding and that there is no permanently installed piping that could serve as } \\
\text { a siphon to lower the water level below the minimum level. (BSC } 2005 \text { b Section } \\
5.1 .5 .12 \text { ) } \\
\text { - The remediation pool shall be designed with the appropriate impact-absorbing } \\
\text { capability to prevent loss of pool integrity, given a drop into the pool of a transportation } \\
\text { cask or site-specific cask having the bounding weight and geometry. (BSC 2005b } \\
\text { Section 5.1.5.13) }\end{array}$ \\
\hline & $\begin{array}{l}\text { Rails for Trolleys, WP } \\
\text { Transporters, and } \\
\text { SRTCs }\end{array}$ & ITS & $\mathrm{SC}$ & $\begin{array}{l}\text { - The rails and rail anchorages within the structure shall be designed for loading } \\
\text { conditions associated with a DBGM-2 seismic event. In addition, it shall be } \\
\text { demonstrated that the rails and rail anchorages have sufficient seismic design margin } \\
\text { to ensure that a "no derailment" safety function }{ }^{3} \text { is maintained for loading conditions } \\
\text { associated with a BDBGM seismic event. (BSC 2004a Table IV-1) }\end{array}$ \\
\hline & $\begin{array}{l}\text { Criticality Prevention } \\
\text { Features, if required } \\
\text { (such as curbs, floor } \\
\text { drains, watertight doors, } \\
\text { walls, barriers, and } \\
\text { seals) }\end{array}$ & ITS & SC & $\begin{array}{l}\text { - Flooding of areas of the structure where moderators are controlled shall be } \\
\text { precluded by passive design features such as drains, flood control channels, curbs, } \\
\text { elevated processing areas, and walls. (BSC 2005b Section 5.1.1.21) }\end{array}$ \\
\hline
\end{tabular}


Table A-I. Nuclear Safety Design Bases of Facilities

\begin{tabular}{|c|c|c|c|c|}
\hline $\begin{array}{l}\text { Facility, System, or } \\
\text { Subsystem }\end{array}$ & $\begin{array}{l}\text { Component or } \\
\text { Function }\end{array}$ & $\begin{array}{l}\text { ITS or } \\
\text { ITWI }\end{array}$ & $\begin{array}{l}\text { Safety } \\
\text { Category }\end{array}$ & Nuclear Safety Design Bases \\
\hline DTF (continued) & $\begin{array}{l}\text { Permanent Shielding } \\
\text { (including shield doors, } \\
\text { shield view ports, and } \\
\text { viewing windows) }\end{array}$ & ITS & SC & $\begin{array}{l}\text { - The DTF permanent shielding (including shield doors, shield view ports, and viewing } \\
\text { windows) shall be designed for loading conditions associated with a DBGM-1 seismic } \\
\text { event to ensure that a "shielding integrity remains intact" safety function }{ }^{3} \text { is maintained. } \\
\text { (BSC 2004a Table IV-1) } \\
\text { - Closure of airlock doors, shield doors, or other applicable doors on a trolley, SRTC, } \\
\text { site-specific cask transporter, WP transporter, other conveyance, or transportation cask } \\
\text { or site-specific cask suspended from an overhead crane shall not cause a tipover of } \\
\text { the conveyance or cause the conveyance or crane to drop its load. (BSC 2005b } \\
\text { Section 5.1.1.13) } \\
\text { - Radiation exposure to workers due to inadvertent actuation of doors shall be } \\
\text { precluded such that this is not a Category } 1 \text { event. (BSC 2005b Section 5.1.1.57) }\end{array}$ \\
\hline \multicolumn{5}{|c|}{ Fuel Handling Facility } \\
\hline FHF & Structure & ITS & SC & 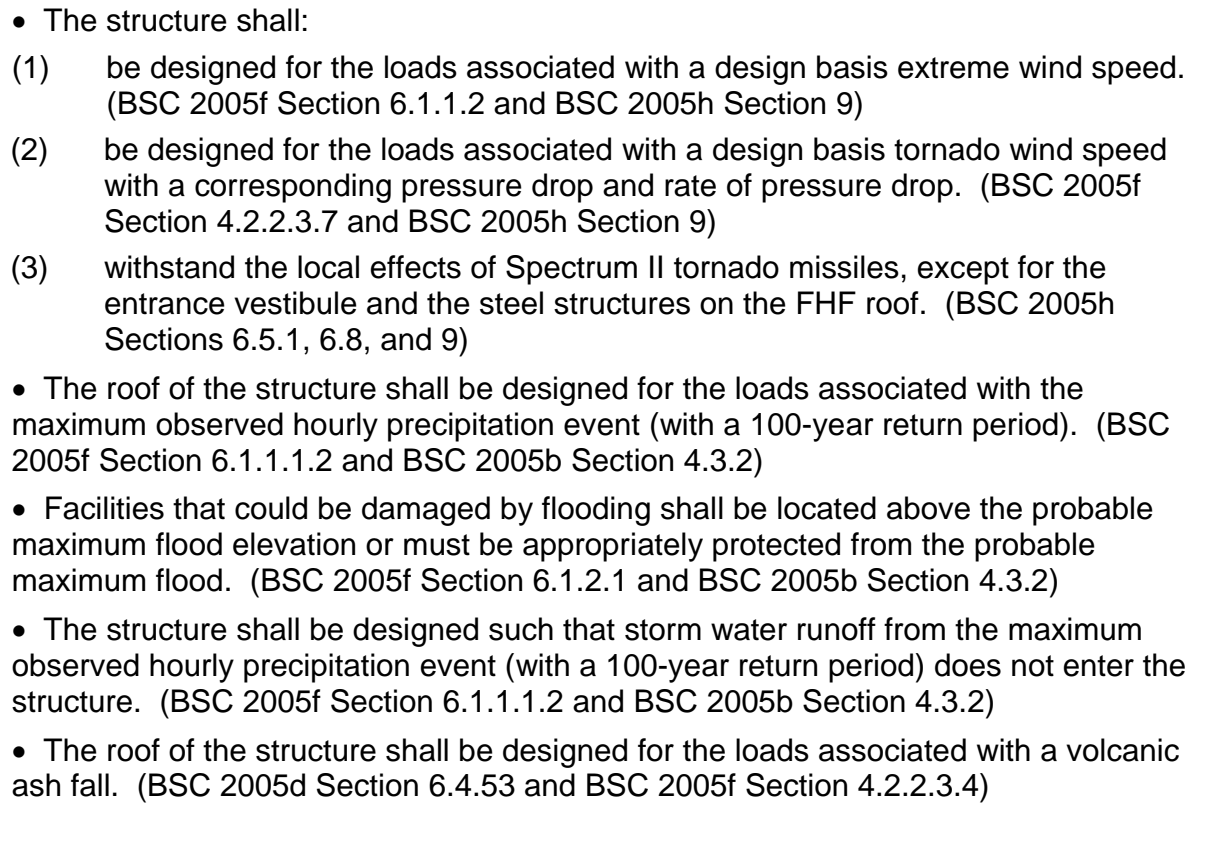 \\
\hline
\end{tabular}


Table A-I. Nuclear Safety Design Bases of Facilities

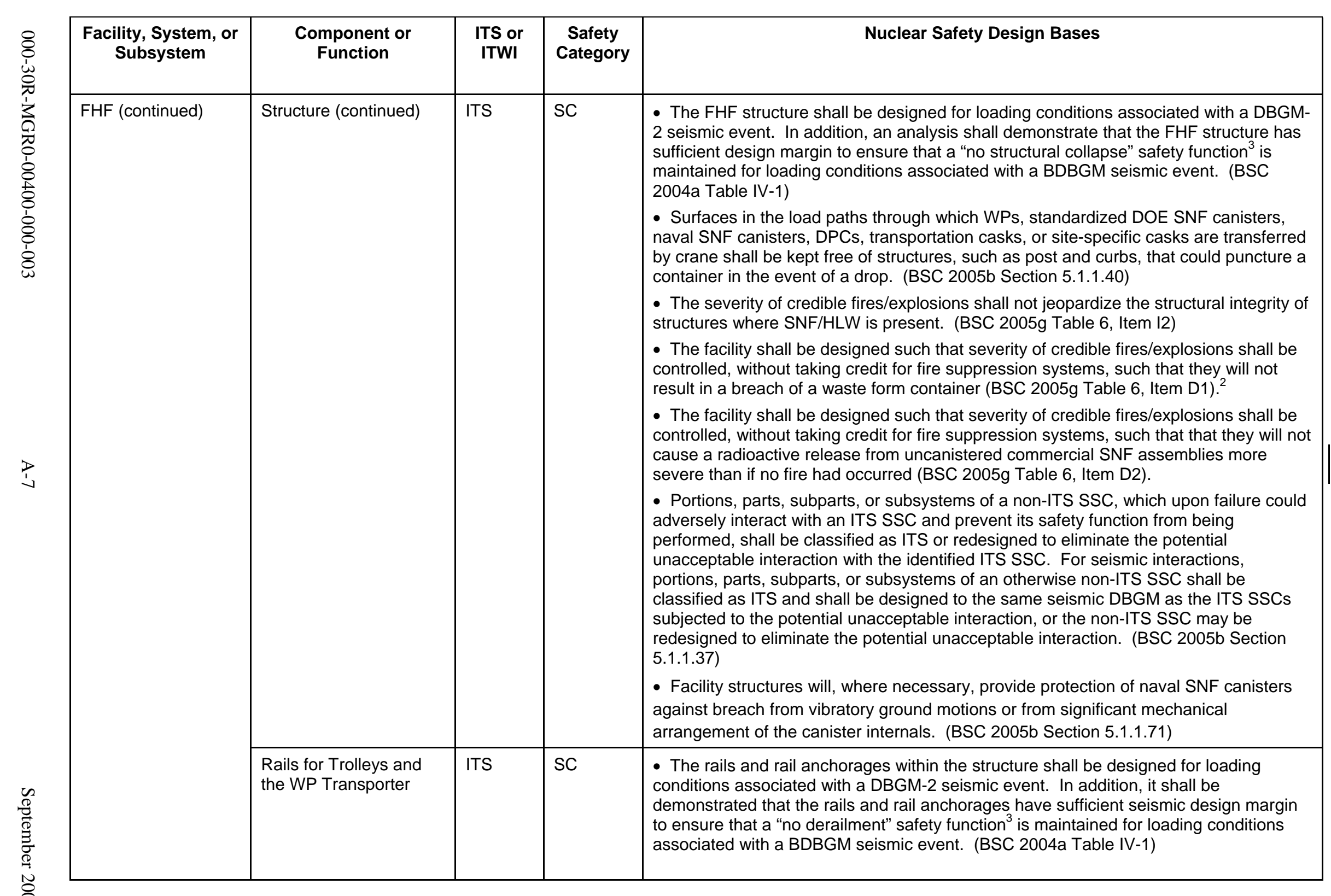


Table A-I. Nuclear Safety Design Bases of Facilities

\begin{tabular}{|c|c|c|c|c|}
\hline $\begin{array}{l}\text { Facility, System, or } \\
\text { Subsystem }\end{array}$ & $\begin{array}{l}\text { Component or } \\
\text { Function }\end{array}$ & $\begin{array}{l}\text { ITS or } \\
\text { ITWI }\end{array}$ & $\begin{array}{l}\text { Safety } \\
\text { Category }\end{array}$ & Nuclear Safety Design Bases \\
\hline \multirow[t]{2}{*}{ FHF (continued) } & $\begin{array}{l}\text { Criticality Prevention } \\
\text { Features, if required } \\
\text { (such as curbs, floor } \\
\text { drains, watertight doors, } \\
\text { walls, barriers, and } \\
\text { seals) }\end{array}$ & ITS & SC & $\begin{array}{l}\text { - Flooding of areas of the structure where moderators are controlled shall be } \\
\text { precluded by passive design features such as drains, flood control channels, curbs, } \\
\text { elevated processing areas, and walls. (BSC 2005b Section 5.1.1.21) }\end{array}$ \\
\hline & $\begin{array}{l}\text { Permanent Shielding } \\
\text { (including shield doors, } \\
\text { shield view ports, and } \\
\text { viewing windows) }\end{array}$ & ITS & SC & $\begin{array}{l}\text { - Closure of airlock doors, shield doors, or other applicable doors shall not cause or } \\
\text { result in a tipover or a dropped load from a trolley, a WP transporter, or from other } \\
\text { conveyance, or drop of a site-specific cask suspended from the vestibule gantry crane. } \\
\text { (BSC 2005b Section 5.1.1.13) } \\
\text { - The FHF permanent shielding (including shield doors, shield view ports, and viewing } \\
\text { windows) shall be designed for loading conditions associated with a DBGM-1 seismic } \\
\text { event to ensure that a "shielding integrity remains intact" safety function }{ }^{3} \text { is maintained. } \\
\text { (BSC 2004a Table IV-1) } \\
\text { - Radiation exposure to workers due to inadvertent actuation of doors shall be } \\
\text { precluded such that this is not a Category } 1 \text { event. (BSC 2005b Section 5.1.1.57) }\end{array}$ \\
\hline \multicolumn{5}{|c|}{ Subsurface Facility } \\
\hline Subsurface Facility & Rails & $N / A$ & Non-SC & $\begin{array}{l}\text { Not Applicable. None of the functions associated with this SSC are credited for the } \\
\text { prevention or mitigation of an event sequence. }\end{array}$ \\
\hline Emplacement & $\begin{array}{l}\text { Nonemplacement } \\
\text { Openings (North Portal, } \\
\text { North Ramp, access } \\
\text { main, and turnouts) }\end{array}$ & ITS & SC & $\begin{array}{l}\text { - The design of the subsurface facility shall ensure that the size and layout of the } \\
\text { waste emplacement transport routes are consistent with the drift and rockfall modeling, } \\
\text { including the evaluation of the characteristics of the credible bounding rockfalls. (BSC } \\
2005 b \text { Section 6.3.6.1.20) } \\
\text { - The ramp, portals, shafts, and shaft collar areas shall be protected from water inflow } \\
\text { as a result of the probable maximum flood. (BSC 2005b Section 4.3.2) } \\
\text { - Portions, parts, subparts, or subsystems of a non-ITS SSC, which upon failure could } \\
\text { adversely interact with an ITS SSC and prevent its safety function from being } \\
\text { performed, shall be classified as ITS or redesigned to eliminate the potential } \\
\text { unacceptable interaction with the identified ITS SSC. For seismic interactions, } \\
\text { portions, parts, subparts, or subsystems of an otherwise non-ITS SSC shall be } \\
\text { classified as ITS and shall be designed to the same seismic DBGM as the ITS SSCs } \\
\text { subjected to the potential unacceptable interaction, or the non-ITS SSC may be } \\
\text { redesigned to eliminate the potential unacceptable interaction. (BSC 2005b Section } \\
\text { 5.1.1.37) }\end{array}$ \\
\hline
\end{tabular}


Table A-I. Nuclear Safety Design Bases of Facilities

\begin{tabular}{|c|c|c|c|c|}
\hline $\begin{array}{l}\text { Facility, System, or } \\
\text { Subsystem }\end{array}$ & $\begin{array}{l}\text { Component or } \\
\text { Function }\end{array}$ & $\begin{array}{l}\text { ITS or } \\
\text { ITWI }\end{array}$ & $\begin{array}{l}\text { Safety } \\
\text { Category }\end{array}$ & Nuclear Safety Design Bases \\
\hline \multirow[t]{7}{*}{$\begin{array}{l}\text { Emplacement } \\
\text { (continued) }\end{array}$} & $\begin{array}{l}\text { Nonemplacement } \\
\text { Openings (other than } \\
\text { North Portal, North } \\
\text { Ramp, access main, } \\
\text { and turnouts) }\end{array}$ & N/A & Non-SC & $\begin{array}{l}\text { Not Applicable. None of the SSC functions associated with this activity are credited for } \\
\text { the prevention or mitigation of an event sequence. }\end{array}$ \\
\hline & $\begin{array}{l}\text { Surface Structures at } \\
\text { Shafts and Raises }\end{array}$ & $N / A$ & Non-SC & $\begin{array}{l}\text { Not Applicable. None of the SSC functions associated with this activity are credited for } \\
\text { the prevention or mitigation of an event sequence. }\end{array}$ \\
\hline & $\begin{array}{l}\text { Ground Support for } \\
\text { Emplacement Drifts and } \\
\text { Nonemplacement } \\
\text { Openings }\end{array}$ & $N / A$ & Non-SC & $\begin{array}{l}\text { Not Applicable. None of the functions associated with this SSC are credited for the } \\
\text { prevention or mitigation of a preclosure event sequence. }\end{array}$ \\
\hline & Emplacement Drift & $\begin{array}{l}\text { ITS } \\
\text { ITWI }\end{array}$ & SC & $\begin{array}{l}\text { - The design of the subsurface facility shall ensure that the size and layout of the } \\
\text { emplacement drifts are consistent with the drift and rockfall modeling, including the } \\
\text { evaluation of the characteristics of the credible bounding rockfalls. (BSC 2005b } \\
\text { Section 6.3.6.1.20) } \\
\text { - Portions, parts, subparts, or subsystems of a non-ITS SSC, which upon failure could } \\
\text { adversely interact with an ITS SSC and prevent its safety function from being } \\
\text { performed, shall be classified as ITS or redesigned to eliminate the potential } \\
\text { unacceptable interaction with the identified ITS SSC. For seismic interactions, } \\
\text { portions, parts, subparts, or subsystems of an otherwise non-ITS SSC shall be } \\
\text { classified as ITS and shall be designed to the same seismic DBGM as the ITS SSCs } \\
\text { subjected to the potential unacceptable interaction, or the non-ITS SSC may be } \\
\text { redesigned to eliminate the potential unacceptable interaction. (BSC 2005b Section } \\
\text { 5.1.1.37) }\end{array}$ \\
\hline & $\begin{array}{l}\text { Emplacement Drift } \\
\text { Invert (Steel) }\end{array}$ & N/A & Non-SC & $\begin{array}{l}\text { Not Applicable. None of the functions associated with this SSC are credited for the } \\
\text { prevention or mitigation of a preclosure event sequence. }\end{array}$ \\
\hline & $\begin{array}{l}\text { Emplacement Drift } \\
\text { Invert (Ballast) }\end{array}$ & ITWI & SC & $\begin{array}{l}\text { Not Applicable. None of the functions associated with this SSC are credited for the } \\
\text { prevention or mitigation of a preclosure event sequence. }\end{array}$ \\
\hline & $\begin{array}{l}\text { WP Emplacement } \\
\text { Pallet }\end{array}$ & $\begin{array}{l}\text { ITS } \\
\text { ITWI }\end{array}$ & SC & $\begin{array}{l}\text { - The WP emplacement pallet shall be designed for loading conditions associated with } \\
\text { a DBGM-2 seismic event and to demonstrate sufficient seismic design margin to } \\
\text { ensure that a "no failure" safety function }{ }^{3} \text { is maintained for loading conditions } \\
\text { associated with a BDBGM seismic event. (BSC 2004a Table IV-1) }\end{array}$ \\
\hline
\end{tabular}


Table A-I. Nuclear Safety Design Bases of Facilities

\begin{tabular}{|c|c|c|c|c|}
\hline $\begin{array}{l}\text { Facility, System, or } \\
\text { Subsystem }\end{array}$ & $\begin{array}{l}\text { Component or } \\
\text { Function }\end{array}$ & $\begin{array}{l}\text { ITS or } \\
\text { ITWI }\end{array}$ & $\begin{array}{l}\text { Safety } \\
\text { Category }\end{array}$ & Nuclear Safety Design Bases \\
\hline \multirow[t]{2}{*}{$\begin{array}{l}\text { Emplacement } \\
\text { (continued) }\end{array}$} & Drip Shield & ITWI & SC & $\begin{array}{l}\text { Not Applicable. None of the functions associated with this SSC are credited for the } \\
\text { prevention or mitigation of a preclosure event sequence. }\end{array}$ \\
\hline & $\begin{array}{l}\text { Drip Shield } \\
\text { Emplacement Gantry }\end{array}$ & $\mathrm{N} / \mathrm{A}$ & Non-SC & $\begin{array}{l}\text { Not Applicable. None of the functions associated with this SSC are credited for the } \\
\text { prevention or mitigation of a preclosure event sequence. }\end{array}$ \\
\hline \multirow[t]{4}{*}{ Postemplacement } & Thermal Management & $\mathrm{N} / \mathrm{A}$ & Non-SC & $\begin{array}{l}\text { Not Applicable. None of the functions associated with this activity are credited for the } \\
\text { prevention or mitigation of a preclosure event sequence. }\end{array}$ \\
\hline & $\begin{array}{l}\text { Closure (magma } \\
\text { bulkheads and backfill } \\
\text { in access mains, } \\
\text { exhaust mains, and } \\
\text { turnouts) }\end{array}$ & ITWI & SC & $\begin{array}{l}\text { Not Applicable. None of the functions associated with this activity are credited for the } \\
\text { prevention or mitigation of a preclosure event sequence. }\end{array}$ \\
\hline & $\begin{array}{l}\text { Closure (other than } \\
\text { magma bulkheads and } \\
\text { backfill in access mains, } \\
\text { exhaust mains, and } \\
\text { turnouts) }\end{array}$ & N/A & Non-SC & $\begin{array}{l}\text { Not Applicable. None of the functions associated with this activity are credited for the } \\
\text { prevention or mitigation of a preclosure event sequence. }\end{array}$ \\
\hline & $\begin{array}{l}\text { Performance } \\
\text { Confirmation }\end{array}$ & N/A & Non-SC & $\begin{array}{l}\text { Not Applicable. None of the functions associated with this activity are credited for the } \\
\text { prevention or mitigation of a preclosure event sequence. }\end{array}$ \\
\hline $\begin{array}{l}\text { Subsurface } \\
\text { Development }\end{array}$ & Excavation & $\mathrm{N} / \mathrm{A}$ & Non-SC & $\begin{array}{l}\text { Not Applicable. None of the functions associated with this activity are credited for the } \\
\text { prevention or mitigation of a preclosure event sequence. }\end{array}$ \\
\hline
\end{tabular}


Table A-I. Nuclear Safety Design Bases of Facilities

\begin{tabular}{|c|c|c|c|c|}
\hline $\begin{array}{l}\text { Facility, System, or } \\
\text { Subsystem }\end{array}$ & $\begin{array}{l}\text { Component or } \\
\text { Function }\end{array}$ & $\begin{array}{l}\text { ITS or } \\
\text { ITWI }\end{array}$ & $\begin{array}{l}\text { Safety } \\
\text { Category }\end{array}$ & Nuclear Safety Design Bases \\
\hline \multicolumn{5}{|c|}{ Transportation Cask Receipt/Return Facility } \\
\hline $\begin{array}{l}\text { Cask Receipt and } \\
\text { Return Area }\end{array}$ & Structure & ITS & SC & 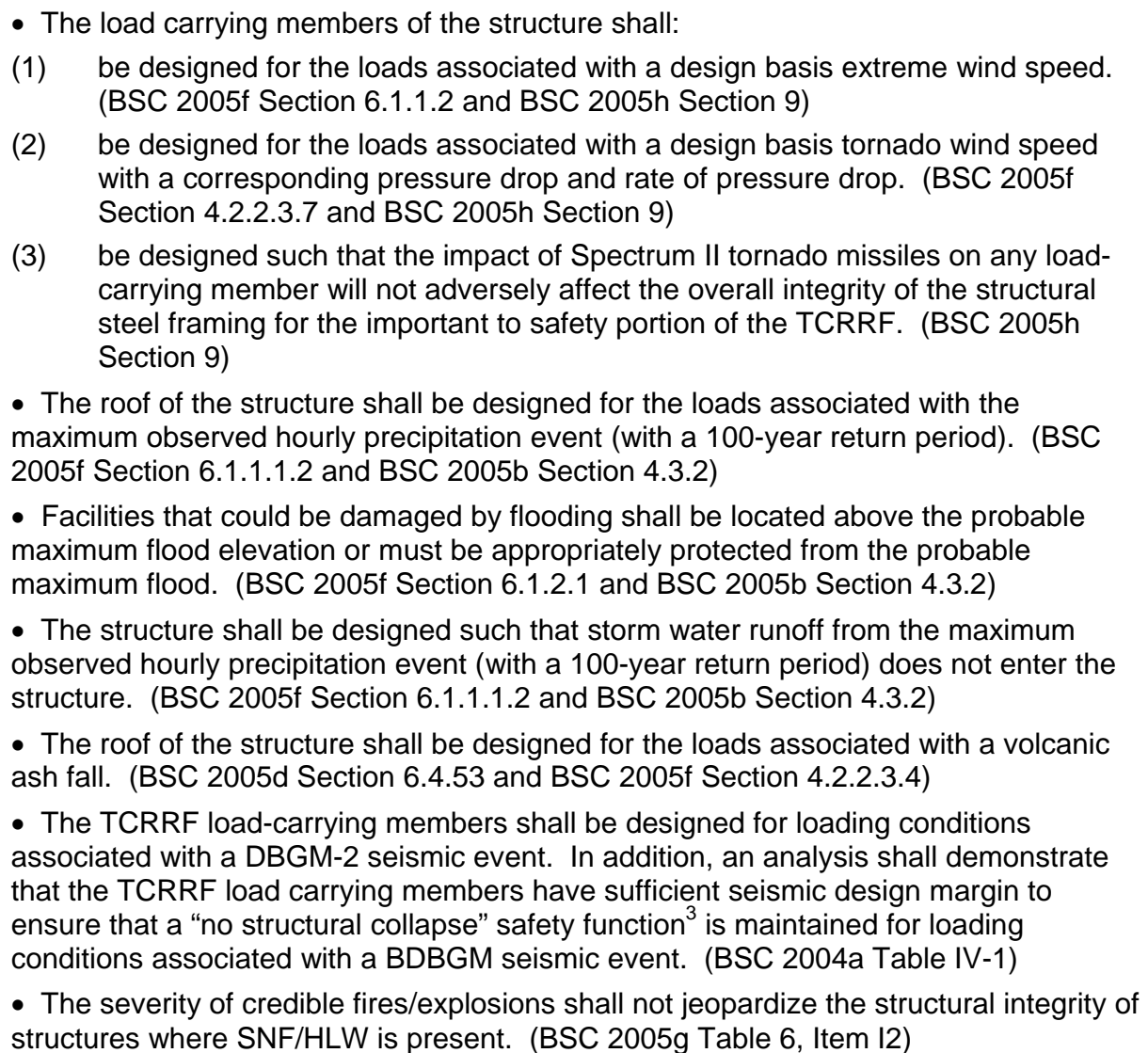 \\
\hline
\end{tabular}


Table A-I. Nuclear Safety Design Bases of Facilities

\begin{tabular}{|c|c|c|c|c|}
\hline $\begin{array}{l}\text { Facility, System, or } \\
\text { Subsystem }\end{array}$ & $\begin{array}{l}\text { Component or } \\
\text { Function }\end{array}$ & $\begin{array}{l}\text { ITS or } \\
\text { ITWI }\end{array}$ & $\begin{array}{l}\text { Safety } \\
\text { Category }\end{array}$ & Nuclear Safety Design Bases \\
\hline \multirow[t]{2}{*}{$\begin{array}{l}\text { Cask Receipt and } \\
\text { Return Area } \\
\text { (continued) }\end{array}$} & Structure (continued) & ITS & SC & $\begin{array}{l}\text { - The facility shall be designed such that severity of credible fires/explosions shall be } \\
\text { controlled, without taking credit for fire suppression systems, such that they will not } \\
\text { result in a breach of a waste form container (BSC } 2005 \mathrm{~g} \text { Table } 6 \text {, Item D1). }{ }^{2} \\
\text { - Portions, parts, subparts, or subsystems of a non-ITS SSC, which upon failure could } \\
\text { adversely interact with an ITS SSC and prevent its safety function from being } \\
\text { performed, shall be classified as ITS or redesigned to eliminate the potential } \\
\text { unacceptable interaction with the identified ITS SSC. For seismic interactions, } \\
\text { portions, parts, subparts, or subsystems of an otherwise non-ITS SSC shall be } \\
\text { classified as ITS and shall be designed to the same seismic DBGM as the ITS SSCs } \\
\text { subjected to the potential unacceptable interaction, or the non-ITS SSC may be } \\
\text { redesigned to eliminate the potential unacceptable interaction. (BSC } 2005 \text { b Section } \\
5.1 .1 .37 \text { ) }\end{array}$ \\
\hline & $\begin{array}{l}\text { Criticality Prevention } \\
\text { Features, if required } \\
\text { (such as curbs, floor } \\
\text { drains, watertight doors, } \\
\text { walls, barriers, and } \\
\text { seals) }\end{array}$ & ITS & SC & $\begin{array}{l}\text { - Flooding of areas of the structure where moderators are controlled shall be } \\
\text { precluded by passive design features such as drains, flood control channels, curbs, } \\
\text { elevated processing areas, and walls. (BSC 2005b Section 5.1.1.21) }\end{array}$ \\
\hline $\begin{array}{l}\text { Transportation Cask } \\
\text { Buffer Area }\end{array}$ & Structure & $\mathrm{N} / \mathrm{A}$ & Non-SC & $\begin{array}{l}\text { Not Applicable. None of the SSC functions associated with this subsystem are } \\
\text { credited for the prevention or mitigation of an event sequence. }\end{array}$ \\
\hline \multicolumn{5}{|c|}{ Warehouse \& Non-Nuclear Receipt Facility } \\
\hline WNNRF & Structure & $\mathrm{N} / \mathrm{A}$ & Non-SC & $\begin{array}{l}\text { Not Applicable. No function of this facility is credited for the prevention or mitigation of } \\
\text { an event sequence. }\end{array}$ \\
\hline
\end{tabular}

NOTES: BDBGM = beyond design basis ground motion; CHF = Canister Handling Facility; DBGM = design basis ground motion; DTF = Dry Transfer Facility; FHF = Fuel Handling Facility; ITS = important to safety; SC = safety category; SRTC = site rail transfer cart; SSC = structure, system, or component; SSCs = structures, systems, and components; TCRRF = Transportation Cask Receipt/Return Facility; WNNRF = Warehouse and Non-Nuclear Receipt Facility. 


\begin{tabular}{|c|c|c|c|c|}
\hline $\begin{array}{l}\text { System or } \\
\text { Subsystem }\end{array}$ & $\begin{array}{l}\text { Component } \\
\text { or Function }\end{array}$ & $\begin{array}{l}\text { ITS or } \\
\text { ITWI }\end{array}$ & $\begin{array}{l}\text { Safety } \\
\text { Category }\end{array}$ & Nuclear Safety Design Bases \\
\hline \multicolumn{5}{|c|}{ Cask/MSC/WP Preparation System } \\
\hline Cask Preparation & $\begin{array}{l}\text { Cask Handling } \\
\text { Crane (CHF); } \\
200 \text { ton }\end{array}$ & ITS & $\mathrm{SC}$ & $\begin{array}{l}\text { - The drop rate for cranes involved in handling waste forms and their associated } \\
\text { containers shall be less than or equal to } 1 \times 10^{-5} \text { drops/transfer, regardless of cause, } \\
\text { including human error, failure of equipment such as yokes and grapples, or a combination } \\
\text { of the two. (BSC } 2005 \mathrm{~b} \text { Section } 5.1 .1 .10 \text { ) } \\
\text { - Upon a loss of power, this crane shall be designed to stop, retain its load, and enter a } \\
\text { locked mode; upon a restoration of power, this crane shall stay in the locked mode until } \\
\text { operator action is taken. (BSC } 2005 \mathrm{~b} \text { Section } 5.1 .2 .1 \text { ) } \\
\text { - The conditional probability of the crane exceeding a lift-height limit, given that a drop has } \\
\text { occurred, shall be less than or equal to } 1 \times 10^{-4} \text {. (BSC 2005b Section 5.1.1.12) } \\
\text { - The lift height limits for the casks handled by this crane are provided in Table C-1 in } \\
\text { Appendix C. These casks include the following: } \\
\text { 1. Transportation casks without impact limiters containing naval SNF canisters. } \\
\text { 2. Transportation casks without impact limiters containing standardized DOE SNF } \\
\text { canisters. } \\
\text { 3. Transportation casks without impact limiters containing DOE HLW canisters and } \\
\text { commercial SNF in vertical DPCs. } \\
\text { 4. Transportation casks without impact limiters containing a DOE MCO. } \\
\text { 5. Site-specific casks with vertical DPCs, standardized DOE SNF canisters, or DOE } \\
\text { HLW canisters. } \\
\text { - This crane and its rigging shall be designed for loading conditions associated with a } \\
\text { DBGM-2 seismic event and to demonstrate sufficient seismic design margin to ensure that } \\
\text { a "no drop" safety function is maintained for loading conditions associated with a BDBGM } \\
\text { seismic event. (BSC } 2004 \text { a Table IV-1) } \\
\text { - This crane shall not be capable of moving above a speed limit for overhead crane } \\
\text { transfers such that a collision at the speed limit would not breach a transportation cask or } \\
\text { site-specific cask. (BSC 2005b Section 5.1.1.19) }\end{array}$ \\
\hline
\end{tabular}




\begin{tabular}{|c|c|c|c|c|}
\hline $\begin{array}{l}\text { System or } \\
\text { Subsystem }\end{array}$ & $\begin{array}{l}\text { Component } \\
\text { or Function }\end{array}$ & $\begin{array}{l}\text { ITS or } \\
\text { ITWI }\end{array}$ & $\begin{array}{l}\text { Safety } \\
\text { Category }\end{array}$ & Nuclear Safety Design Bases \\
\hline & $\begin{array}{l}\text { Cask Handling } \\
\text { Crane (DTF); } \\
200 \text { ton }\end{array}$ & ITS & SC & $\begin{array}{l}\text { - The drop rate for cranes involved in handling waste forms and their associated } \\
\text { containers shall be less than or equal to } 1 \times 10^{-5} \text { drops/transfer, regardless of cause, } \\
\text { including human error, failure of equipment such as yokes and grapples, or a combination } \\
\text { of the two. (BSC } 2005 \mathrm{~b} \text { Section } 5.1 .1 .10 \text { ) } \\
\text { - Upon a loss of power, this crane shall be designed to stop, retain its load, and enter a } \\
\text { locked mode; upon a restoration of power, this crane shall stay in the locked mode until } \\
\text { operator action is taken. (BSC } 2005 \mathrm{~b} \text { Section } 5.1 .2 .1 \text { ) } \\
\text { - The conditional probability of the crane exceeding a lift-height limit, given that a drop has } \\
\text { occurred, shall be less than or equal to } 1 \times 10^{-4} \text {. (BSC } 2005 \mathrm{~b} \text { Section } 5.1 .1 .12 \text { ) } \\
\text { - The lift height limits for the casks handled by this crane are provided in Table C-1 in } \\
\text { Appendix C; these casks include: } \\
\text { 1. Transportation casks without impact limiters containing standardized DOE SNF } \\
\text { canisters, DOE HLW canisters, commercial SNF, or vertical or horizontal DPCs. } \\
\text { 2. Site-specific casks containing commercial SNF, standardized DOE SNF canisters, } \\
\text { DOE HLW canisters, or vertical or horizontal DPCs. } \\
\text { 3. Transportation casks without impact limiters containing a DOE MCO. } \\
\text { - This crane and its rigging shall be designed for loading conditions associated with a } \\
\text { DBGM-2 seismic event and to demonstrate sufficient seismic design margin to ensure that } \\
\text { a "no drop" safety function }{ }^{3} \text { is maintained for loading conditions associated with a BDBGM } \\
\text { seismic event. (BSC } 2004 a \text { Table IV-1) }\end{array}$ \\
\hline
\end{tabular}




\begin{tabular}{|c|c|c|c|c|}
\hline $\begin{array}{l}\text { System or } \\
\text { Subsystem }\end{array}$ & $\begin{array}{l}\text { Component } \\
\text { or Function }\end{array}$ & $\begin{array}{l}\text { ITS or } \\
\text { ITWI }\end{array}$ & $\begin{array}{l}\text { Safety } \\
\text { Category }\end{array}$ & Nuclear Safety Design Bases \\
\hline \multirow[t]{2}{*}{$\begin{array}{l}\text { Cask Preparation } \\
\text { (continued) }\end{array}$} & $\begin{array}{l}\text { Cask Handling } \\
\text { Crane (DTF); } \\
200 \text { ton } \\
\text { (continued) }\end{array}$ & ITS & SC & $\begin{array}{l}\text { - This crane shall not be capable of moving above a speed limit for overhead crane } \\
\text { transfers such that a collision at the speed limit would not breach a transportation cask or } \\
\text { site-specific cask. (BSC 2005b Section 5.1.1.19) } \\
\text { - This crane shall not be capable of exerting sufficient force during transfer to breach a } \\
\text { cask as the result of attempts to overcome mechanical constraints. (BSC } 2005 \mathrm{~b} \text { Section } \\
5.1 .1 .20 \text { ) } \\
\text { - The severity of credible fires/explosions in areas where the waste forms are present } \\
\text { shall not cause the handling equipment that handles SNF/HLW to drop its load. (BSC } \\
2005 \mathrm{~g} \text { Table } 6 \text {, Item I1) } \\
\text { - Cranes and other machinery that handle SNF/HLW shall be designed to minimize the } \\
\text { probability of occurrence of uncontrolled movements resulting from a loss of power or from } \\
\text { spurious signals initiated by a credible fire/explosion, such as to render a potential event } \\
\text { sequence Beyond Category 2. (BSC } 2005 \mathrm{~g} \text { Table } 6 \text {, Item I3) }\end{array}$ \\
\hline & $\begin{array}{l}\text { Naval Cask } \\
\text { Handling Crane } \\
\text { (DTF); } 200 \text { ton }\end{array}$ & ITS & SC & $\begin{array}{l}\text { - The drop rate for cranes involved in handling waste forms and their associated } \\
\text { containers shall be less than or equal to } 1 \times 10^{-5} \text { drops/transfer, regardless of cause, } \\
\text { including human error, failure of equipment such as yokes and grapples, or a combination } \\
\text { of the two. (BSC 2005b Section } 5.1 .1 .10 \text { ) } \\
\text { - Upon a loss of power, this crane shall be designed to stop, retain its load, and enter a } \\
\text { locked mode; upon a restoration of power, this crane shall stay in the locked mode until } \\
\text { operator action is taken. (BSC } 2005 \mathrm{~b} \text { Section } 5.1 .2 .1 \text { ) } \\
\text { - The conditional probability of the crane exceeding a lift-height limit, given that a drop has } \\
\text { occurred, shall be less than or equal to } 1 \times 10^{-4} \text {. (BSC } 2005 \mathrm{~b} \text { Section } 5.1 .1 .12 \text { ) } \\
\text { - The lift height limit for transportation casks without impact limiters containing a naval } \\
\text { SNF canister is provided in Table C- } 1 \text { in Appendix C. } \\
\text { - This crane and its rigging shall be designed for loading conditions associated with a } \\
\text { DBGM-2 seismic event and to demonstrate sufficient seismic design margin to ensure that } \\
\text { a "no drop" safety function is maintained for loading conditions associated with a BDBGM } \\
\text { seismic event. (BSC 2004a Table IV-1) }\end{array}$ \\
\hline
\end{tabular}




\begin{tabular}{|c|c|c|c|c|}
\hline $\begin{array}{l}\text { System or } \\
\text { Subsystem }\end{array}$ & $\begin{array}{l}\text { Component } \\
\text { or Function }\end{array}$ & $\begin{array}{l}\text { ITS or } \\
\text { ITWI }\end{array}$ & $\begin{array}{l}\text { Safety } \\
\text { Category }\end{array}$ & Nuclear Safety Design Bases \\
\hline & Turntables (DTF) & ITS & $\mathrm{SC}$ & $\begin{array}{l}\text { - Turntables shall be designed for stability and prevention of a tipover of any waste } \\
\text { container on the table for loading conditions associated with a DBGM-2 seismic event. In } \\
\text { addition, an analysis shall demonstrate that the turntable has sufficient seismic design } \\
\text { margin to ensure that a "no tipover" safety function }{ }^{3} \text { is maintained for loading conditions } \\
\text { associated with a BDBGM seismic event. (BSC } 2004 \text { a Table IV-1) } \\
\text { - The severity of credible fires/explosions in areas where the waste forms are present } \\
\text { shall not cause the handling equipment that handles SNF/HLW to drop its load. (BSC } \\
2005 \mathrm{~g} \text { Table 6, Item I1) } \\
\text { - Machinery that handles SNF/HLW shall be designed to minimize the probability of } \\
\text { occurrence of uncontrolled movements resulting from a loss of power or from spurious } \\
\text { signals initiated by a credible fire/explosion, such as to render a potential event sequence } \\
\text { Beyond Category 2. (BSC } 2005 \mathrm{~g} \text { Table 6, Item I3) }\end{array}$ \\
\hline
\end{tabular}




\begin{tabular}{|c|c|c|c|c|}
\hline $\begin{array}{l}\text { System or } \\
\text { Subsystem }\end{array}$ & $\begin{array}{l}\text { Component } \\
\text { or Function }\end{array}$ & $\begin{array}{l}\text { ITS or } \\
\text { ITWI }\end{array}$ & $\begin{array}{l}\text { Safety } \\
\text { Category }\end{array}$ & Nuclear Safety Design Bases \\
\hline \multirow[t]{5}{*}{$\begin{array}{l}\text { Cask Preparation } \\
\text { (continued) }\end{array}$} & $\begin{array}{l}\text { Cask Docking } \\
\text { Ring (DTF, FHF) }\end{array}$ & $\mathrm{N} / \mathrm{A}$ & Non-SC & $\begin{array}{l}\text { Not applicable. No function of this SSC is credited for the prevention or mitigation of an } \\
\text { event sequence. }\end{array}$ \\
\hline & $\begin{array}{l}\text { Cask Pit, } \\
\text { Pedestal; } \\
\text { (CHF) }\end{array}$ & $\mathrm{N} / \mathrm{A}$ & Non-SC & $\begin{array}{l}\text { Not applicable. No function of this SSC is credited for the prevention or mitigation of an } \\
\text { event sequence. }\end{array}$ \\
\hline & $\begin{array}{l}\text { Cask Shielded Pit } \\
\text { Cover (CHF) }\end{array}$ & ITS & SC & $\begin{array}{l}\text { - The cask pit protective cover shall be designed for loading conditions associated with a } \\
\text { DBGM-1 seismic event to ensure that a "shielding integrity remains intact" safety function } \\
\text { is maintained. (BSC 2004a Table IV-1) } \\
\text { - The cask pit protective cover shall be sturdy enough to prevent a WP or site-specific } \\
\text { cask that is dropped on the pit cover from penetrating the pit cover and falling into the pit. } \\
\text { (BSC 2005b Section 5.1.6.6) } \\
\text { - Radiation exposure to workers due to inadvertent actuation of the pit protective covers } \\
\text { shall be precluded such that this is not a Category } 1 \text { event. (BSC 2005b Section 5.1.1.57) }\end{array}$ \\
\hline & $\begin{array}{l}\text { Pit Crush Pad } \\
\text { (CHF) }\end{array}$ & ITS & SC & $\begin{array}{l}\text { - Crush pads shall limit the impact energy of a dropped canister, cask, or WP to be less } \\
\text { than or equal to the impact energy associated with a drop of a canister, cask, or WP onto } \\
\text { an unyielding surface from their maximum specified drop height for the canister, cask, or } \\
\text { WP }^{6} \text {. (BSC 2005b Sections 5.1.1.18 and 5.1.1.52) }\end{array}$ \\
\hline & $\begin{array}{l}\text { Entrance } \\
\text { Vestibule Crane } \\
\text { (FHF); } 200 \text { ton }\end{array}$ & ITS & $\mathrm{SC}$ & $\begin{array}{l}\text { - The drop rate for cranes involved in handling waste forms and their associated } \\
\text { containers shall be less than or equal to } 1 \times 10^{-5} \text { drops/transfer, regardless of cause, } \\
\text { including human error, failure of equipment such as yokes and grapples, or a combination } \\
\text { of the two. (BSC 2005b Section 5.1.1.10) } \\
\text { - Upon a loss of power, this crane shall be designed to stop, retain its load, and enter a } \\
\text { locked mode; upon a restoration of power, this crane shall stay in the locked mode until } \\
\text { operator action is taken. (BSC 2005b Section 5.1.2.1) } \\
\text { - The conditional probability of the crane exceeding a lift-height limit, given that a drop has } \\
\text { occurred, shall be less than or equal to } 1 \times 10^{-4} \text {. (BSC 2005b Section 5.1.1.12) }\end{array}$ \\
\hline
\end{tabular}




\begin{tabular}{|c|c|c|c|c|}
\hline $\begin{array}{l}\text { System or } \\
\text { Subsystem }\end{array}$ & $\begin{array}{l}\text { Component } \\
\text { or Function }\end{array}$ & $\begin{array}{l}\text { ITS or } \\
\text { ITWI }\end{array}$ & $\begin{array}{l}\text { Safety } \\
\text { Category }\end{array}$ & Nuclear Safety Design Bases \\
\hline $\begin{array}{l}\text { Cask Preparation } \\
\text { (continued) }\end{array}$ & $\begin{array}{l}\text { Entrance } \\
\text { Vestibule Crane } \\
\text { (FHF); } 200 \text { ton } \\
\text { (continued) }\end{array}$ & ITS & SC & $\begin{array}{l}\text { - The lift height limits for the casks handled by this crane are provided in Table C-1 in } \\
\text { Appendix C; these casks include: } \\
\text { 1. Transportation cask without impact limiters containing naval SNF canisters. } \\
\text { 2. Transportation cask without impact limiters containing standardized DOE SNF } \\
\text { canisters or DOE HLW canisters. } \\
\text { 3. Transportation cask without impact limiters or site-specific cask containing } \\
\text { commercial SNF or DPCs. } \\
\text { 4. Site-specific casks containing vertical DPCs, standardized DOE SNF canisters, or } \\
\text { DOE HLW canisters. } \\
\text { - This crane and its rigging shall be designed for loading conditions associated with a } \\
\text { DBGM-2 seismic event and to demonstrate sufficient seismic design margin to ensure that } \\
\text { a "no drop" safety function }{ }^{3} \text { is maintained for loading conditions associated with a BDBGM } \\
\text { seismic event. (BSC } 2004 \text { a Table IV-1) } \\
\text { - This crane shall not be capable of moving above a speed limit for overhead crane } \\
\text { transfers such that a collision at the speed limit would not breach a transportation cask or } \\
\text { site-specific cask. (BSC } 2005 \mathrm{~b} \text { Section } 5.1 .1 .19 \text { ) } \\
\text { - This crane shall not be capable of exerting sufficient force during transfer to breach a } \\
\text { cask, WP, or site-specific cask as the result of attempts to overcome mechanical } \\
\text { constraints. (BSC 2005b Section } 5.1 .1 .20 \text { ) } \\
\text { - The severity of credible fires/explosions in areas where the waste forms are present } \\
\text { shall not cause the handling equipment that handles SNF/HLW to drop its load. (BSC } \\
\text { 2005g Table } 6 \text {, Item I1) } \\
\text { - Cranes and other machinery that handle SNF/HLW shall be designed to minimize the } \\
\text { probability of occurrence of uncontrolled movements resulting from a loss of power or from } \\
\text { spurious signals initiated by a credible fire/explosion, such as to render a potential event } \\
\text { sequence Beyond Category 2. (BSC } 2005 g \text { Table } 6 \text {, Item I3) }\end{array}$ \\
\hline
\end{tabular}




\begin{tabular}{|l|l|l|l|l|}
\hline \multicolumn{1}{|c|}{$\begin{array}{c}\text { System or } \\
\text { Subsystem }\end{array}$} & $\begin{array}{c}\text { Component } \\
\text { or Function }\end{array}$ & $\begin{array}{c}\text { ITS or } \\
\text { ITWI }\end{array}$ & $\begin{array}{c}\text { Safety } \\
\text { Category }\end{array}$ & Nuclear Safety Design Bases \\
\hline $\begin{array}{l}\text { Cask Preparation } \\
\text { (continued) }\end{array}$ & $\begin{array}{l}\text { Main Transfer } \\
\text { Room Crane } \\
\text { (FHF); 200 ton } \\
\text { (continued) }\end{array}$ & ITS & SC & $\begin{array}{l}\text { - This crane shall not be capable of exerting sufficient force to breach a cask, WP, } \\
\text { canister, or site-specific cask during transfer as the result of attempts to overcome } \\
\text { mechanical constraints. (BSC 2005b Section 5.1.1.20) } \\
\text { The severity of credible fires/explosions in areas where the waste forms are present } \\
\text { shall not cause the handling equipment that handles SNF/HLW to drop its load. (BSC } \\
\text { 2005g Table 6, Item I1) } \\
\text { Cranes and other machinery that handle SNF/HLW shall be designed to minimize the } \\
\text { probability of occurrence of uncontrolled movements resulting from a loss of power or from } \\
\text { spurious signals initiated by a credible fire/explosion, such as to render a potential event } \\
\text { sequence Beyond Category 2. (BSC 2005g Table 6, Item I3) }\end{array}$ \\
\cline { 2 - 5 } & $\begin{array}{l}\text { Mobile Elevating } \\
\text { Platform }\end{array}$ & N/A & Non-SC & $\begin{array}{l}\text { Not applicable. No function of this SSC is credited for the prevention or mitigation of an } \\
\text { event sequence. }\end{array}$ \\
\cline { 2 - 5 } & $\begin{array}{l}\text { Cask Pit Movable } \\
\text { Platform (CHF) }\end{array}$ & N/A & Non-SC & $\begin{array}{l}\text { Not applicable. No function of this SSC is credited for the prevention or mitigation of an } \\
\text { event sequence. }\end{array}$ \\
\hline
\end{tabular}




\begin{tabular}{|c|c|c|c|c|}
\hline $\begin{array}{l}\text { System or } \\
\text { Subsystem }\end{array}$ & $\begin{array}{l}\text { Component } \\
\text { or Function }\end{array}$ & $\begin{array}{l}\text { ITS or } \\
\text { ITWI }\end{array}$ & $\begin{array}{l}\text { Safety } \\
\text { Category }\end{array}$ & Nuclear Safety Design Bases \\
\hline $\begin{array}{l}\text { Cask Preparation } \\
\text { (continued) }\end{array}$ & $\begin{array}{l}\text { Cask Trolleys, } \\
\text { Pedestals, and } \\
\text { Hold-Down } \\
\text { Devices (DTF, } \\
\text { FHF) }\end{array}$ & ITS & SC & 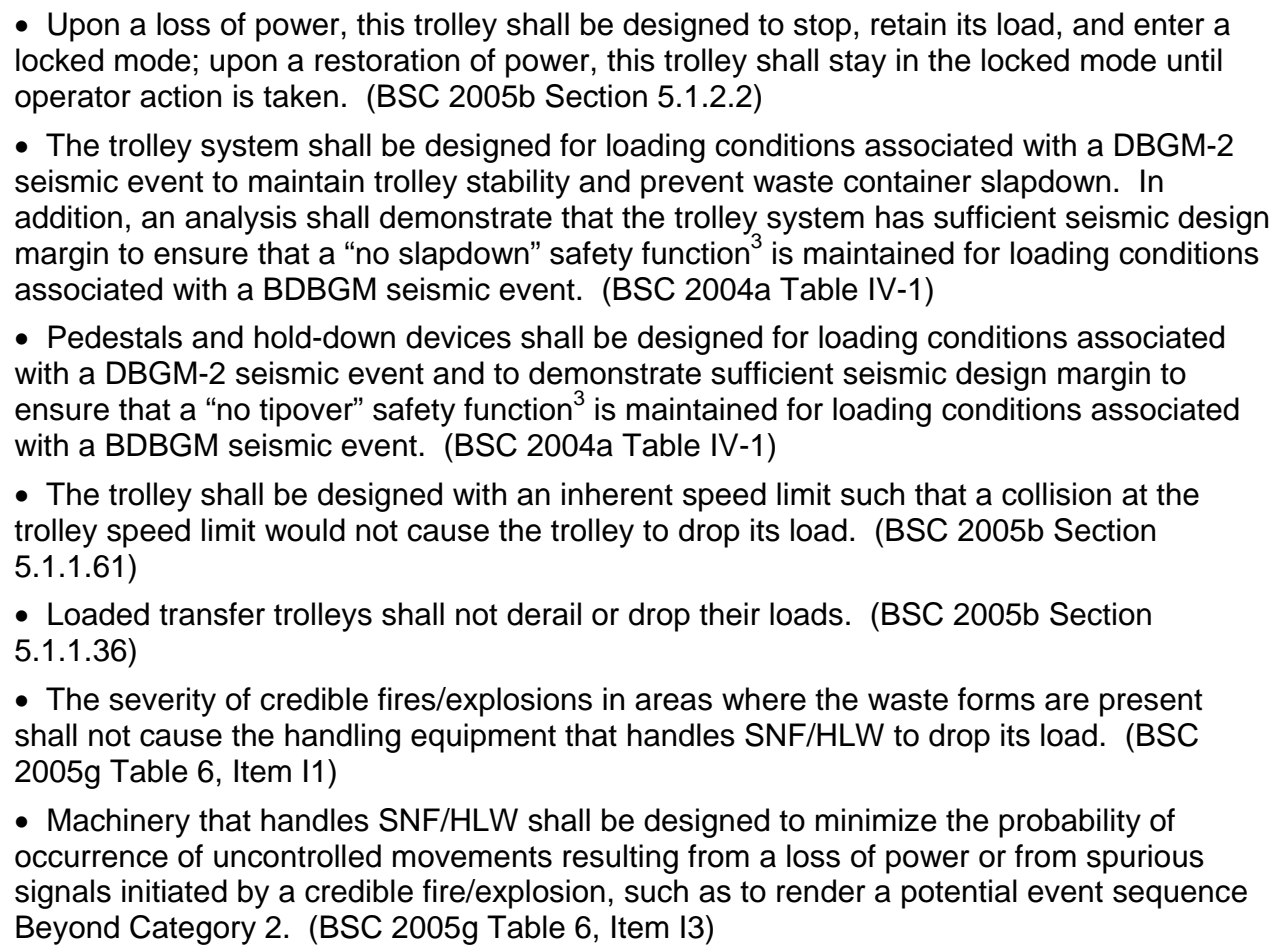 \\
\hline
\end{tabular}




\begin{tabular}{|c|c|c|c|c|}
\hline $\begin{array}{l}\text { System or } \\
\text { Subsystem }\end{array}$ & $\begin{array}{l}\text { Component } \\
\text { or Function }\end{array}$ & $\begin{array}{l}\text { ITS or } \\
\text { ITWI }\end{array}$ & $\begin{array}{l}\text { Safety } \\
\text { Category }\end{array}$ & Nuclear Safety Design Bases \\
\hline WP Preparation & $\begin{array}{l}\text { WP Trolleys, } \\
\text { Pedestals, and } \\
\text { Hold-Down } \\
\text { Devices (DTF, } \\
\text { CHF, FHF) }\end{array}$ & ITS & SC & $\begin{array}{l}\text { - Upon a loss of power, this trolley shall be designed to stop, retain its load, and enter a } \\
\text { locked mode; upon a restoration of power, this trolley shall stay in the locked mode until } \\
\text { operator action is taken. (BSC 2005b Section 5.1.2.2) } \\
\text { - WP trolleys shall be designed for loading conditions associated with a DBGM-2 seismic } \\
\text { event and to demonstrate sufficient seismic design margin to ensure that a "no tipover" } \\
\text { safety function }{ }^{3} \text { is maintained for loading conditions associated with a BDBGM seismic } \\
\text { event. (BSC 2004a Table IV-1) } \\
\text { - Pedestals and hold-down devices shall be designed for loading conditions associated } \\
\text { with a DBGM-2 seismic event and to demonstrate sufficient seismic design margin to } \\
\text { ensure that a "no slapdown" safety function is maintained for loading conditions } \\
\text { associated with a BDBGM seismic event. (BSC 2004a Table IV-1) } \\
\text { - The trolley shall be designed with an inherent speed limit such that a collision at the } \\
\text { trolley speed limit would not cause the trolley to drop its load. (BSC 2005b Section } \\
\text { 5.1.1.61) } \\
\text { - Loaded transfer trolleys shall not derail or drop their loads. (BSC } 2005 \text { b Section } \\
\text { 5.1.1.36) } \\
\text { - The severity of credible fires/explosions in areas where the waste forms are present } \\
\text { shall not cause the handling equipment that handles SNF/HLW to drop its load. (BSC } \\
2005 \mathrm{~g} \text { Table } 6 \text {, Item I1) } \\
\text { - Machinery that handles SNF/HLW shall be designed to minimize the probability of } \\
\text { occurrence of uncontrolled movements resulting from a loss of power or from spurious } \\
\text { signals initiated by a credible fire/explosion, such as to render a potential event sequence } \\
\text { Beyond Category 2. (BSC } 2005 \mathrm{~g} \text { Table } 6 \text {, Item I3) }\end{array}$ \\
\hline & $\begin{array}{l}\text { WP Docking Ring } \\
\text { (DTF, FHF) }\end{array}$ & $\mathrm{N} / \mathrm{A}$ & Non-SC & $\begin{array}{l}\text { Not applicable. No function of this SSC is credited for the prevention or mitigation of an } \\
\text { event sequence. }\end{array}$ \\
\hline
\end{tabular}




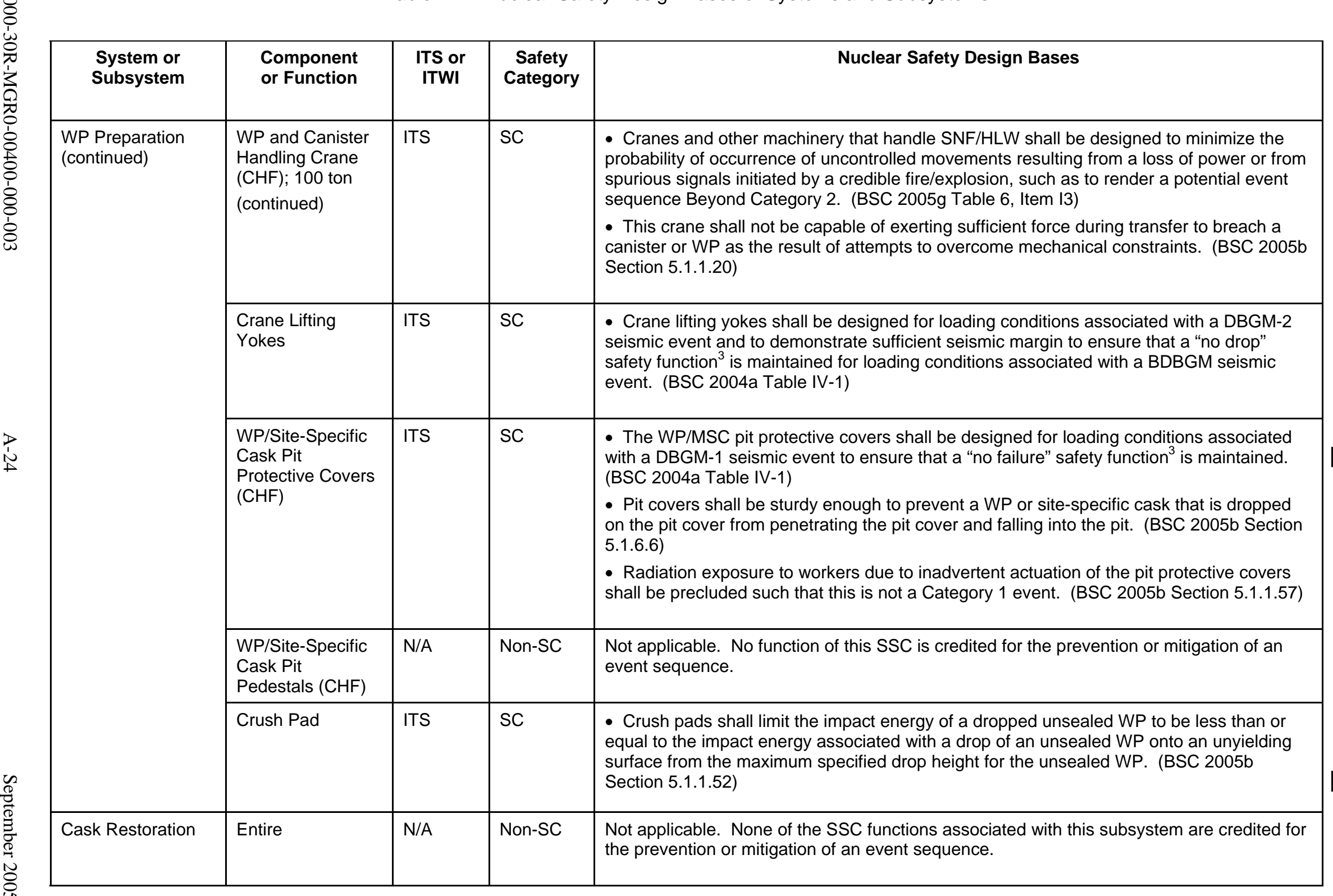




\begin{tabular}{|c|c|c|c|c|}
\hline $\begin{array}{l}\text { System or } \\
\text { Subsystem }\end{array}$ & $\begin{array}{l}\text { Component } \\
\text { or Function }\end{array}$ & $\begin{array}{l}\text { ITS or } \\
\text { ITWI }\end{array}$ & $\begin{array}{l}\text { Safety } \\
\text { Category }\end{array}$ & Nuclear Safety Design Bases \\
\hline \multicolumn{5}{|c|}{ Cask Receipt and Return System } \\
\hline \multirow[t]{6}{*}{ SRTC Buffer } & SRTC & ITS & SC & $\begin{array}{l}\text { - In the instances when the SRTC moves a cask without impact limiters (typically only } \\
\text { within structures), the SRTC shall prevent slapdown of the cask for loading conditions } \\
\text { associated with a DBGM-2 seismic event. In addition, an analysis shall demonstrate that } \\
\text { the SRTC transporting a cask without impact limiters has sufficient seismic design margin } \\
\text { to ensure that a "no slapdown" safety function }{ }^{3} \text { is maintained for loading conditions } \\
\text { associated with a BDBGM seismic event. (BSC } 2004 \text { a Table IV-1) } \\
\text { - A speed limit for which SRTCs will be pulled/pushed by the SRTC tractor shall be } \\
\text { established such that a collision with shield or airlock doors or other heavy objects does } \\
\text { not overturn the SRTC or cause it to lose its load. (BSC } 2005 \text { b Section 5.1.1.38) } \\
\text { - In the instances where the SRTC moves a cask without impact limiters (typically only } \\
\text { within structures) an SRTC carrying a transportation cask or a site-specific cask shall not } \\
\text { derail and the transportation cask or site-specific cask shall not fall from the SRTC under } \\
\text { normal operating conditions or as the result of a collision. (BSC 2005b Section 5.1.1.35) }\end{array}$ \\
\hline & SRTC Rails & N/A & Non-SC & $\begin{array}{l}\text { Not applicable. No function of this SSC is credited for the prevention or mitigation of an } \\
\text { event sequence. }\end{array}$ \\
\hline & SRTC Positioner & N/A & Non-SC & $\begin{array}{l}\text { Not applicable. No function of this SSC is credited for the prevention or mitigation of an } \\
\text { event sequence. }\end{array}$ \\
\hline & $\begin{array}{l}\text { SRTC Positioner } \\
\text { Turntable }\end{array}$ & N/A & Non-SC & $\begin{array}{l}\text { Not applicable. No function of this SSC is credited for the prevention or mitigation of an } \\
\text { event sequence. }\end{array}$ \\
\hline & SRTC Turntables & N/A & Non-SC & $\begin{array}{l}\text { Not applicable. No function of this SSC is credited for the prevention or mitigation of an } \\
\text { event sequence. }\end{array}$ \\
\hline & SRTC Tractor & N/A & Non-SC & $\begin{array}{l}\text { Not applicable. No function of this SSC is credited for the prevention or mitigation of an } \\
\text { event sequence. }\end{array}$ \\
\hline
\end{tabular}




\begin{tabular}{|c|c|c|c|c|}
\hline $\begin{array}{l}\text { System or } \\
\text { Subsystem }\end{array}$ & $\begin{array}{l}\text { Component } \\
\text { or Function }\end{array}$ & $\begin{array}{l}\text { ITS or } \\
\text { ITWI }\end{array}$ & $\begin{array}{l}\text { Safety } \\
\text { Category }\end{array}$ & Nuclear Safety Design Bases \\
\hline \multirow[t]{2}{*}{$\begin{array}{l}\text { Cask Receipt and } \\
\text { Return (continued) }\end{array}$} & $\begin{array}{l}\text { Crane Lifting } \\
\text { Yokes }\end{array}$ & ITS & $\mathrm{SC}$ & $\begin{array}{l}\text { - The crane lifting yokes shall be designed for loading conditions associated with a } \\
\text { DBGM-2 seismic event and to demonstrate sufficient seismic margin to ensure that a "no } \\
\text { drop" safety function }{ }^{3} \text { is maintained for loading conditions associated with a BDBGM } \\
\text { seismic event. (BSC 2004a Table IV-1) }\end{array}$ \\
\hline & Crush Pad & ITS & SC & $\begin{array}{l}\text { - Crush pads shall limit the impact energy of a dropped cask to be less than or equal to } \\
\text { the impact energy associated with a drop of a cask onto an unyielding surface from the } \\
\text { maximum specified drop height for the cask. (BSC 2005b Section 5.1.1.18) }\end{array}$ \\
\hline \multicolumn{5}{|r|}{ Communications System } \\
\hline Communications & Entire & N/A & Non-SC & $\begin{array}{l}\text { Not applicable. None of the SSC functions associated with these subsystems are credited } \\
\text { for the prevention or mitigation of an event sequence. }\end{array}$ \\
\hline \multicolumn{5}{|c|}{ Digital Control and Management Information System } \\
\hline $\begin{array}{l}\text { Digital Control and } \\
\text { Management } \\
\text { Information }\end{array}$ & Entire & N/A & Non-SC & $\begin{array}{l}\text { Not applicable. No function of this SSC is credited for the prevention or mitigation of an } \\
\text { event sequence. }\end{array}$ \\
\hline \multicolumn{5}{|c|}{ DOE and Commercial WP System } \\
\hline $\begin{array}{l}\text { DOE and } \\
\text { Commercial WP }\end{array}$ & Waste Package & $\begin{array}{l}\text { ITS } \\
\text { ITWI }\end{array}$ & SC & $\begin{array}{l}\text { Sealed WPs shall withstand without breaching the following drops: (BSC } 2005 \mathrm{~b} \text { Section } \\
\text { 5.1.3.12) } \\
\text { A. Free-drop of } 6.5 \mathrm{ft} \text { from a vertical orientation onto a horizontal surface (trunnion } \\
\text { collars installed) } \\
\text { B. Free-drop of } 7.8 \mathrm{ft} \text { from a horizontal orientation onto a horizontal surface (trunnion } \\
\text { collars installed) } \\
\text { C. Free-drop with the emplacement pallet from a horizontal orientation onto a horizontal } \\
\text { surface (trunnion collars not installed) of } 6.5 \mathrm{ft} \text { from the bottom of the emplacement } \\
\text { pallet }\end{array}$ \\
\hline
\end{tabular}




\begin{tabular}{|c|c|c|c|c|}
\hline $\begin{array}{l}\text { System or } \\
\text { Subsystem }\end{array}$ & $\begin{array}{l}\text { Component } \\
\text { or Function }\end{array}$ & $\begin{array}{l}\text { ITS or } \\
\text { ITWI }\end{array}$ & $\begin{array}{l}\text { Safety } \\
\text { Category }\end{array}$ & Nuclear Safety Design Bases \\
\hline $\begin{array}{l}\text { DOE and } \\
\text { Commercial WP } \\
\text { (continued) }\end{array}$ & $\begin{array}{l}\text { Waste Package } \\
\text { (continued) }\end{array}$ & $\begin{array}{l}\text { ITS } \\
\text { ITWI }\end{array}$ & SC & $\begin{array}{l}\text { - Sealed WPs shall withstand without breaching the following drops (continued): (BSC } \\
\text { 2005b Section 5.1.3.12) } \\
\text { D. Tip-over onto a horizontal surface from a } 6.5 \mathrm{ft} \text { elevated surface (trunnion collars } \\
\text { installed) } \\
\text { E. Tip-over onto the tilting machine, including contact with the trunnion cradles or the } \\
\text { floor (trunnion collars installed). } \\
\text { Note: Drop and tip-over event sequences shall be evaluated for worst possible (most } \\
\text { damaging) credible conditions including initial geometric position and weight of } \\
\text { contents. An unyielding, flat horizontal surface may be used to bound the } \\
\text { consequences of a drop. Drops shall include attendant swing-down and/or slap- } \\
\text { down from the indicated position, with or without trunnion collars attached, as } \\
\text { appropriate. } \\
\text { - WPs, in a horizontal orientation on an emplacement pallet, shall be lifted in accordance } \\
\text { with the lift height limits in Table C-1 in Appendix C. } \\
\text { - WPs in a vertical orientation shall be lifted in accordance with the lift height limits in } \\
\text { Table C-1 in Appendix C. } \\
\text { - WPs shall withstand a single rockfall of } 1.2 \times 10^{5} \text { joules or less without breaching. (BSC } \\
\text { 2005b Section 6.3.6.1.20) } \\
\text { - WPs shall withstand two consecutive rockfalls having a total kinetic energy of } 1.0 \times 10^{5} \\
\text { joules or less without breaching. (BSC } 2005 b \text { Section } 6.3 .6 .1 .20 \text { ) } \\
\text { - WPs shall be designed for loading conditions associated with a DBGM-2 seismic event } \\
\text { and to demonstrate sufficient seismic design margin to ensure that "no breach" and "no } \\
\text { criticality" safety functions }{ }^{3} \text { are maintained for loading conditions associated with a BDBGM } \\
\text { seismic event. (BSC } 2004 a \text { Table IV-1) } \\
\text { - The size of the berth in a WP shall be restricted such that a DOE MCO cannot be tilted } \\
\text { more than an angle of } 3 \text { degrees from vertical upon impact with the floor of the berth. } \\
\text { (BSC } 2005 b \text { Section } 5.1 .1 .15 \text { ) }\end{array}$ \\
\hline
\end{tabular}




\begin{tabular}{|c|c|c|c|c|}
\hline $\begin{array}{l}\text { System or } \\
\text { Subsystem }\end{array}$ & $\begin{array}{l}\text { Component } \\
\text { or Function }\end{array}$ & $\begin{array}{l}\text { ITS or } \\
\text { ITWI }\end{array}$ & $\begin{array}{l}\text { Safety } \\
\text { Category }\end{array}$ & Nuclear Safety Design Bases \\
\hline \multirow[t]{2}{*}{$\begin{array}{l}\text { DOE and } \\
\text { Commercial WP } \\
\text { (continued) }\end{array}$} & $\begin{array}{l}\text { Waste Package } \\
\text { (continued) }\end{array}$ & $\begin{array}{l}\text { ITS } \\
\text { ITWI }\end{array}$ & SC & $\begin{array}{l}\text { - Sealed WPs shall be designed such that drops, collisions, and other handling impacts } \\
\text { within the WP design bases (allowing for rearrangement of container internals, proximity of } \\
\text { other sealed WPs, and without credit for burnup) cannot lead to a nuclear criticality. (BSC } \\
\text { 2005b Section 5.1.3.1) } \\
\text { - WPs shall be designed, with credit for moderator control and without credit for burnup, } \\
\text { such that: (BSC 2005b Section 5.1.3.2) } \\
\text { A. WPs configured for commercial SNF can be loaded with any combination of } \\
\text { commercial SNF assemblies that are acceptable for disposal without leading } \\
\text { to a preclosure nuclear criticality. } \\
\text { B. DOE codisposal WPs can be loaded with any combination of DOE canisters } \\
\text { (including standardized DOE SNF canisters, MCOs, and DOE HLW canisters) } \\
\text { that fit in the basket positions without leading to a preclosure nuclear criticality. } \\
\text { The demonstration of criticality safety must account for credible } \\
\text { rearrangements of fissile material that may occur during normal operations or } \\
\text { due to a Category } 1 \text { or Category } 2 \text { event sequence involving a drop or other } \\
\text { impact. } \\
\text { - An unsealed WP that is dropped from within } 2 \mathrm{ft} \text { above an essentially unyielding flat } \\
\text { surface shall not spill its contents. (BSC } 2005 \mathrm{~b} \text { Section 5.1.3.11) }\end{array}$ \\
\hline & Trunnion Collar & ITS & SC & $\begin{array}{l}\text { - Trunnion collars shall be designed for loading conditions associated with a DBGM-2 } \\
\text { seismic event and to demonstrate sufficient seismic design margin to ensure a "no drop" } \\
\text { safety function }{ }^{3} \text { is maintained for loading conditions associated with a BDBGM seismic } \\
\text { event. (BSC 2004a Table IV-1) }\end{array}$ \\
\hline
\end{tabular}




\begin{tabular}{|c|c|c|c|c|}
\hline $\begin{array}{l}\text { System or } \\
\text { Subsystem }\end{array}$ & $\begin{array}{l}\text { Component } \\
\text { or Function }\end{array}$ & $\begin{array}{l}\text { ITS or } \\
\text { ITWI }\end{array}$ & $\begin{array}{l}\text { Safety } \\
\text { Category }\end{array}$ & Nuclear Safety Design Bases \\
\hline \multicolumn{5}{|c|}{ DOE SNF Disposable Canister } \\
\hline $\begin{array}{l}\text { DOE SNF } \\
\text { Disposable } \\
\text { Canister }\end{array}$ & $\begin{array}{l}\text { Standardized } \\
\text { DOE SNF } \\
\text { Canister }\end{array}$ & ITS & $\mathrm{SC}$ & $\begin{array}{l}\text { - The probability that a standardized DOE SNF canister is defective such that it may } \\
\text { breach if dropped in any orientation from a height of } 23 \mathrm{ft} \text { onto an essentially unyielding flat } \\
\text { surface shall be } 2.3 \times 10^{-4} \text { or less. (BSC } 2005 \mathrm{~b} \text { Section } 4.1 .18 \text { ) } \\
\text { - A standardized DOE SNF canister in a cask, WP, staging rack, or staging pit, shall } \\
\text { withstand without breach a drop of a DOE HLW canister onto it from } 2 \mathrm{ft} \text { above the floor of } \\
\text { the transfer cell and from } 23 \mathrm{ft} \text { above the floor of the cask, WP, staging rack, or staging pit. } \\
\text { (BSC } 2005 \mathrm{~b} \text { Section } 5.1 .1 .25 \text { ) } \\
\text { - A standardized DOE SNF canister shall not breach if dropped onto a structural corner, } \\
\text { such as the edge of a cask, WP, pit, or load-port, or onto a cask basket or WP internal } \\
\text { baffle, from the most limiting height, as follows (BSC } 2005 \mathrm{~b} \text { Section } 5.1 .1 .29 \text { ): } \\
\text { A. } 23 \mathrm{ft} \text { above the floor of the cask, WP, staging rack, or staging pit. } \\
\text { B. } 2 \mathrm{ft} \text { above the floor of the transfer cell. } \\
\text { - A standardized DOE SNF canister shall not breach if lifted in accordance with the lift } \\
\text { height limits in Table C-1 in Appendix C. } \\
\text { - A standardized DOE SNF canister shall capable of meeting loading conditions } \\
\text { associated with a DBGM-2 seismic event and to demonstrate sufficient seismic margin to } \\
\text { ensure that "no breach" and "no criticality" safety functions }{ }^{3} \text { are maintained for loading } \\
\text { conditions associated with a BDBGM seismic event. (BSC } 2004 a \text { Table IV-1) } \\
\text { - A standardized DOE SNF canister shall withstand without breach a drop of another } \\
\text { standardized DOE SNF canister on top of it from } 23 \mathrm{ft} \text { above the floor of a cask, WP, } \\
\text { staging rack or staging pit and from } 2 \mathrm{ft} \text { above the floor of the transfer cell. (BSC } 2005 \mathrm{~b} \\
\text { Section } 5.1 .1 .28 \text { ) } \\
\text { - A drop of a standardized DOE SNF canister shall not lead to a nuclear criticality. (BSC } \\
\text { 2005b Section 5.1.1.3) }\end{array}$ \\
\hline
\end{tabular}




\begin{tabular}{|c|c|c|c|c|}
\hline $\begin{array}{l}\text { System or } \\
\text { Subsystem }\end{array}$ & $\begin{array}{l}\text { Component } \\
\text { or Function }\end{array}$ & $\begin{array}{l}\text { ITS or } \\
\text { ITWI }\end{array}$ & $\begin{array}{l}\text { Safety } \\
\text { Category }\end{array}$ & Nuclear Safety Design Bases \\
\hline \multirow{2}{*}{$\begin{array}{l}\text { DOE SNF } \\
\text { Disposable } \\
\text { Canister } \\
\text { (continued) }\end{array}$} & $\begin{array}{l}\text { DOE HLW } \\
\text { Canister }\end{array}$ & ITS & SC & $\begin{array}{l}\text { - A DOE HLW canister shall be capable of meeting loading conditions associated with a } \\
\text { DBGM-2 seismic event and to demonstrate sufficient seismic design margin to a "no } \\
\text { breach" safety function }{ }^{3} \text {. (BSC 2004a Table IV-1, BSC 2005b Section 5.1.2.8) }\end{array}$ \\
\hline & $\begin{array}{l}\text { Internal Geometry } \\
\text { Control }\end{array}$ & ITS & SC & $\begin{array}{l}\text { - The DOE SNF disposable canister internal geometry control shall be capable of meeting } \\
\text { loading conditions associated with a DBGM-2 seismic event and to demonstrate sufficient } \\
\text { seismic design margin to ensure that a "no criticality" safety function }{ }^{3} \text { is maintained for } \\
\text { loading conditions associated with a BDBGM seismic event. (BSC 2004a Table IV-1) }\end{array}$ \\
\hline
\end{tabular}




\begin{tabular}{|c|c|c|c|c|}
\hline $\begin{array}{l}\text { System or } \\
\text { Subsystem }\end{array}$ & $\begin{array}{l}\text { Component } \\
\text { or Function }\end{array}$ & $\begin{array}{l}\text { ITS or } \\
\text { ITWI }\end{array}$ & $\begin{array}{l}\text { Safety } \\
\text { Category }\end{array}$ & Nuclear Safety Design Bases \\
\hline \multicolumn{5}{|r|}{ Dual-Purpose Canister } \\
\hline DPC & Entire & ITS & SC & $\begin{array}{l}\text { - DPCs shall be designed to ensure nuclear criticality safety with optimum moderation and } \\
\text { the most reactive waste forms. Criticality safety will be maintained despite any geometric } \\
\text { rearrangements due to a drop or other handling incident. (BSC 2005b Section 5.1.1.4) }\end{array}$ \\
\hline \multicolumn{5}{|r|}{ Electrical Power System } \\
\hline $\begin{array}{l}\text { Switchyard and } \\
\text { Standby Power }\end{array}$ & $\begin{array}{l}\text { Line End } \\
\text { Transmission } \\
\text { Tower; Line Side } \\
\text { High Voltage } \\
\text { Disconnect } \\
\text { Switch; High } \\
\text { Voltage Breaker, } \\
\text { Load Side High } \\
\text { Voltage } \\
\text { Disconnect } \\
\text { Switch; Main } \\
\text { Transformer; and } \\
\text { Non-segregated } \\
\text { Phase Bus to } \\
12.47 \text { kV Main } \\
\text { Switchgear }\end{array}$ & ITS & $\mathrm{SC}$ & $\begin{array}{l}\text { - Electrical power system components shall provide reliable power to the DTF and FHF } \\
\text { Surface Nuclear HVAC Primary Confinement Subsystem to meet the performance criteria } \\
\text { in accordance with the Surface Nuclear HVAC Primary Confinement Subsystem nuclear } \\
\text { safety design bases. (BSC 2005b Section 5.1.1.48, BSC 2004c Table 9) }\end{array}$ \\
\hline
\end{tabular}


Table A-II. Nuclear Safety Design Bases of Systems and Subsystems

\begin{tabular}{|c|c|c|c|c|}
\hline $\begin{array}{l}\text { System or } \\
\text { Subsystem }\end{array}$ & $\begin{array}{l}\text { Component } \\
\text { or Function }\end{array}$ & $\begin{array}{l}\text { ITS or } \\
\text { ITWI }\end{array}$ & $\begin{array}{l}\text { Safety } \\
\text { Category }\end{array}$ & Nuclear Safety Design Bases \\
\hline $\begin{array}{l}\text { Switchyard and } \\
\text { Standby Power } \\
\text { (continued) }\end{array}$ & $\begin{array}{l}\text { Standby Diesel } \\
\text { Generators and } \\
\text { SSCs other than } \\
\text { Line End } \\
\text { Transmission } \\
\text { Tower; Line Side } \\
\text { High Voltage } \\
\text { Disconnect } \\
\text { Switch; High } \\
\text { Voltage Breaker; } \\
\text { Load Side High } \\
\text { Voltage } \\
\text { Disconnect } \\
\text { Switch; Main } \\
\text { Transformer; and } \\
\text { Nonsegregated } \\
\text { Phase Bus to } \\
\text { 12.47kV Main } \\
\text { Switchgear }\end{array}$ & $\mathrm{N} / \mathrm{A}$ & Non-SC & $\begin{array}{l}\text { Not applicable. None of the SSC functions associated with this subsystem are credited for } \\
\text { the prevention or mitigation of an event sequence. }\end{array}$ \\
\hline Normal Power & $\begin{array}{l}\text { 12.47kV Main } \\
\text { Switchgear; } \\
12.47 \mathrm{kV} \text { to } 4.16 \mathrm{kV} \\
\text { Distribution } \\
\text { Transformer to } \\
\text { Emergency } \\
\text { Switchgear Bus A; } \\
12.47 \mathrm{kV} \text { to } 4.16 \mathrm{kV} \\
\text { Distribution } \\
\text { Transformer to } \\
\text { Emergency } \\
\text { Switchgear Bus B }\end{array}$ & ITS & SC & $\begin{array}{l}\text { - Electrical power system components shall provide reliable power to the DTF and FHF } \\
\text { Surface Nuclear HVAC Primary Confinement Subsystem to meet the performance criteria } \\
\text { in accordance with the Surface Nuclear HVAC Primary Confinement Subsystem nuclear } \\
\text { safety design bases. (BSC 2005b Section 5.1.1.48; BSC 2004c Table 9) }\end{array}$ \\
\hline
\end{tabular}


Table A-II. Nuclear Safety Design Bases of Systems and Subsystems

\begin{tabular}{|c|c|c|c|c|}
\hline $\begin{array}{l}\text { System or } \\
\text { Subsystem }\end{array}$ & $\begin{array}{l}\text { Component } \\
\text { or Function }\end{array}$ & $\begin{array}{l}\text { ITS or } \\
\text { ITWI }\end{array}$ & $\begin{array}{l}\text { Safety } \\
\text { Category }\end{array}$ & Nuclear Safety Design Bases \\
\hline $\begin{array}{l}\text { Normal Power } \\
\text { (continued) }\end{array}$ & $\begin{array}{l}\text { Normal Power } \\
\text { Subsystem SSCs } \\
\text { other than } \\
12.47 \mathrm{kV} \text { Main } \\
\text { Switchgear; } \\
12.47 \mathrm{kV} \text { to } 4.16 \mathrm{kV} \\
\text { Distribution } \\
\text { Transformer } \\
\text { to Emergency } \\
\text { Switchgear Bus A; } \\
12.47 \mathrm{kV} \text { to 4.16kV } \\
\text { Distribution } \\
\text { Transformer to } \\
\text { Emergency } \\
\text { Switchgear Bus B } \\
\text { (includes 4.16kV } \\
\text { Switchgear Buses } \\
\text { A, B, C, D, E, F, } \\
\text { G, H, J, K, L, M, } \\
\text { N, and P; 12.47kV } \\
\text { Switchgear C } \\
\text { and D [located at } \\
\text { South Service } \\
\text { Portal]) }\end{array}$ & N/A & Non-SC & $\begin{array}{l}\text { Not applicable. None of the SSC functions associated with this subsystem are credited for } \\
\text { the prevention or mitigation of an event sequence. }\end{array}$ \\
\hline
\end{tabular}




\begin{tabular}{|l|l|l|l|l|}
\hline \multicolumn{1}{|c|}{$\begin{array}{c}\text { System or } \\
\text { Subsystem }\end{array}$} & $\begin{array}{c}\text { Component } \\
\text { or Function }\end{array}$ & $\begin{array}{c}\text { ITS or } \\
\text { ITWI }\end{array}$ & $\begin{array}{c}\text { Safety } \\
\text { Category }\end{array}$ & Nuclear Safety Design Bases \\
\hline Emergency Power & $\begin{array}{l}\text { 4.16kV } \\
\text { Emergency } \\
\text { Switchgear Bus A } \\
\text { and B; Emergency } \\
\text { Load Center } \\
\text { Transformers for } \\
\text { DTF 1, DTF 2, } \\
\text { and FHF; } \\
\text { Emergency Load } \\
\text { Centers and Motor } \\
\text { Control Centers } \\
\text { located in DTF 1, } \\
\text { DTF 2, and FHF; } \\
\text { and Feeders Up } \\
\text { To and Including } \\
\text { the ITS Loads }\end{array}$ & ITS & SC & $\begin{array}{l}\text { E Electrical power system components shall provide reliable power to the DTF and FHF } \\
\text { Surface Nuclear HVAC Primary Confinement Subsystem to meet the performance criteria } \\
\text { in accordance with the Surface Nuclear HVAC Primary Confinement Subsystem nuclear } \\
\text { safety design bases. (BSC 2005b Section 5.1.1.48, BSC 2004c Table 9) }\end{array}$ \\
\hline
\end{tabular}




\begin{tabular}{|c|c|c|c|c|}
\hline $\begin{array}{l}\text { System or } \\
\text { Subsystem }\end{array}$ & $\begin{array}{l}\text { Component } \\
\text { or Function }\end{array}$ & $\begin{array}{l}\text { ITS or } \\
\text { ITWI }\end{array}$ & $\begin{array}{l}\text { Safety } \\
\text { Category }\end{array}$ & Nuclear Safety Design Bases \\
\hline $\begin{array}{l}\text { Emergency Power } \\
\text { (continued) }\end{array}$ & $\begin{array}{l}\text { Emergency Diesel } \\
\text { Generators A } \\
\text { and B and SSCs } \\
\text { other than 4.16kV } \\
\text { Emergency } \\
\text { Switchgear Buses } \\
\text { A and B; } \\
\text { Emergency Load } \\
\text { Center } \\
\text { Transformers for } \\
\text { DTF 1, DTF 2, } \\
\text { and FHF; } \\
\text { Emergency Load } \\
\text { Centers and } \\
\text { MCCs located in } \\
\text { DTF 1, DTF 2, } \\
\text { and FHF; and } \\
\text { Feeders Up To } \\
\text { and Including the } \\
\text { ITS Loads }\end{array}$ & N/A & Non-SC & $\begin{array}{l}\text { Not applicable. None of the SSC functions associated with this subsystem are credited for } \\
\text { the prevention or mitigation of an event sequence. }\end{array}$ \\
\hline \multicolumn{5}{|r|}{ Electrical Support System } \\
\hline Lighting & Entire & N/A & Non-SC & $\begin{array}{l}\text { Not applicable. None of the SSC functions associated with this subsystem are credited for } \\
\text { the prevention or mitigation of an event sequence. }\end{array}$ \\
\hline Grounding & Entire & N/A & Non-SC & $\begin{array}{l}\text { Not applicable. None of the SSC functions associated with this subsystem are credited for } \\
\text { the prevention or mitigation of an event sequence. }\end{array}$ \\
\hline $\begin{array}{l}\text { Lightning } \\
\text { Protection }\end{array}$ & Entire & N/A & Non-SC & $\begin{array}{l}\text { Not applicable. None of the SSC functions associated with this subsystem are credited for } \\
\text { the prevention or mitigation of an event sequence. }\end{array}$ \\
\hline Cathodic Protection & Entire & $N / A$ & Non-SC & $\begin{array}{l}\text { Not applicable. None of the SSC functions associated with this subsystem are credited for } \\
\text { the prevention or mitigation of an event sequence. }\end{array}$ \\
\hline
\end{tabular}




\begin{tabular}{|l|l|l|l|l|}
\hline \multicolumn{1}{|c|}{$\begin{array}{c}\text { System or } \\
\text { Subsystem }\end{array}$} & $\begin{array}{l}\text { Component } \\
\text { or Function }\end{array}$ & $\begin{array}{c}\text { ITS or } \\
\text { ITWI }\end{array}$ & $\begin{array}{l}\text { Safety } \\
\text { Category }\end{array}$ & \multicolumn{1}{|c|}{ Nuclear Safety Design Bases } \\
\hline Heat Tracing & Entire & N/A & Non-SC & $\begin{array}{l}\text { Not applicable. None of the SSC functions associated with this subsystem are credited for } \\
\text { the prevention or mitigation of an event sequence. }\end{array}$ \\
\hline Cable Raceway & $\begin{array}{l}\text { The portion of } \\
\text { cable raceway } \\
\text { subsystem that } \\
\text { supports the } \\
\text { equipment and } \\
\text { components in the }\end{array}$ & ITS & SC & $\begin{array}{l}\text { - The portion of the cable raceway subsystem that supports ITS functions of the } \\
\text { emergency power subsystem shall provide reliable power to the DTF and FHF Surface } \\
\text { Nuclear HVAC Primary Confinement System to meet the performance criteria in } \\
\text { accordance with the Surface Nuclear HVAC Primary Confinement System nuclear safety } \\
\text { design bases. (BSC 2005b Section 5.1.1.48) }\end{array}$ \\
$\begin{array}{l}\text { System that are } \\
\text { classified as ITS } \\
\text { (including portions } \\
\text { of the switchyard, } \\
12.47 \mathrm{kV} \text { main } \\
\text { switchgear A and } \\
\text { B, 4.16 kV } \\
\text { emergency bus A } \\
\text { and B, 480 V } \\
\text { emergency load } \\
\text { centers and motor } \\
\text { control centers, } \\
125 \mathrm{VDC} \text { and } 120 \\
\text { V AC UPS) }\end{array}$ & & & \\
\hline
\end{tabular}


Table A-II. Nuclear Safety Design Bases of Systems and Subsystems

\begin{tabular}{|l|l|l|l|l|}
\hline \multicolumn{1}{|c|}{$\begin{array}{c}\text { System or } \\
\text { Subsystem }\end{array}$} & $\begin{array}{l}\text { Component } \\
\text { or Function }\end{array}$ & $\begin{array}{c}\text { ITS or } \\
\text { ITWI }\end{array}$ & $\begin{array}{c}\text { Safety } \\
\text { Category }\end{array}$ & \\
\hline $\begin{array}{l}\text { Cable Raceway } \\
\text { (continued) }\end{array}$ & $\begin{array}{l}\text { The portion of the } \\
\text { cable raceway } \\
\text { subsystem that } \\
\text { supports Non-SC } \\
\text { functions of the } \\
\text { Electrical Power } \\
\text { System (including } \\
\text { portions of the } \\
\text { normal power } \\
\text { subsystem, } \\
\text { switchgear and } \\
\text { standby power } \\
\text { subsystem, and } \\
\text { emergency power } \\
\text { subsystem } \\
\text { [including } \\
\text { emergency diesel } \\
\text { generators]) }\end{array}$ & Non-SC & $\begin{array}{l}\text { Not applicable. None of the SSC functions associated with this subsystem are credited for } \\
\text { the prevention or mitigation of an event sequence. }\end{array}$ & \\
\hline
\end{tabular}




\begin{tabular}{|c|c|c|c|c|}
\hline $\begin{array}{l}\text { System or } \\
\text { Subsystem }\end{array}$ & $\begin{array}{l}\text { Component } \\
\text { or Function }\end{array}$ & $\begin{array}{l}\text { ITS or } \\
\text { ITWI }\end{array}$ & $\begin{array}{l}\text { Safety } \\
\text { Category }\end{array}$ & Nuclear Safety Design Bases \\
\hline \multicolumn{5}{|c|}{ Emplacement and Retrieval System } \\
\hline WP Transportation & WP Transporter & ITS & $\mathrm{SC}$ & $\begin{array}{l}\text { - The WP transporter shall transport the WP in a manner such that if a collision or } \\
\text { derailment (excluding tipover) occurs, the WP impact energy will be low enough to } \\
\text { preclude a WP breach; this impact energy translates into a maximum WP transporter } \\
\text { speed of } 15 \text { mph. (BSC 2005b Section 5.1.7.3) } \\
\text { - The WP transporter shall transport the WP in a manner such that if a collision or } \\
\text { derailment leading to a WP transporter tipover occurs, the WP impact energy will be low } \\
\text { enough to preclude a WP breach. (BSC 2005b Section 5.1.7.7) } \\
\text { - While on the surface, the WP transporter shall be designed to function in extreme } \\
\text { straight wind (90 mph). (BSC 2005b Section 4.1.13) } \\
\text { - The WP transporter or its bedplate shall not collide with a WP on the WP turntable and } \\
\text { cause a WP breach. (BSC 2005b Section 5.1.1.39) } \\
\text { - The rate of a WP transporter runaway shall be less than } 8.3 \times 10^{-9} \text { runaways per WP } \\
\text { trip. (BSC } 2005 \text { bection 5.1.7.8) } \\
\text { - The WP transporter (together with the locomotive and coupler) shall be designed to } \\
\text { prevent runaway of the WP transporter for loading conditions associated with a DBGM-2 } \\
\text { seismic event. In addition, an analysis shall demonstrate that the WP transporter (together } \\
\text { with the locomotive and coupler) has sufficient seismic design margin to ensure that a "no } \\
\text { runaway" safety function }{ }^{3} \text { is maintained for loading conditions associated with a BDBGM } \\
\text { seismic event. (BSC } 2004 a \text { Table IV-1) } \\
\text { - The WP transporter shall be designed such that severity of credible fires/explosions shall } \\
\text { be controlled, without taking credit for fire suppression systems, such that they will not } \\
\text { result in a breach of a waste form container (BSC } 2005 \mathrm{~g} \text { Table } 6 \text {, Item D1). }\end{array}$ \\
\hline
\end{tabular}




\begin{tabular}{|c|c|c|c|c|}
\hline $\begin{array}{l}\text { System or } \\
\text { Subsystem }\end{array}$ & $\begin{array}{l}\text { Component } \\
\text { or Function }\end{array}$ & $\begin{array}{l}\text { ITS or } \\
\text { ITWI }\end{array}$ & $\begin{array}{l}\text { Safety } \\
\text { Category }\end{array}$ & Nuclear Safety Design Bases \\
\hline $\begin{array}{l}\text { WP Transportation } \\
\text { (continued) }\end{array}$ & $\begin{array}{l}\text { WP Transporter } \\
\text { (continued) }\end{array}$ & ITS & SC & $\begin{array}{l}\text { - The WP transporter shall be designed for loading conditions associated with a DBGM-1 } \\
\text { seismic event to ensure that a "shielding integrity remains intact" safety function }{ }^{3} \text { is } \\
\text { maintained. (BSC 2004a Table IV-1) } \\
\text { - The transporter shielded compartment shall withstand any fall of failed ground support } \\
\text { materials, as well as a set of rockfalls having a total mass of 5.4 MT, without jeopardizing } \\
\text { the structural integrity of the WP. (BSC 2005b Section 6.3.6.1.9) } \\
\text { - Movement of the WP transporter shielded enclosure doors shall not breach the WP or } \\
\text { cause it to fall from the bedplate of the transporter. (BSC } 2005 \mathrm{~b} \text { Section } 5.1 .7 .2 \text { ) } \\
\text { - The restraints used to immobilize the bedplate inside the shielded compartment of the } \\
\text { WP transporter and the mechanism for locking the doors of the shielded compartment shall } \\
\text { withstand a collision or derailment (including tipover) of the transporter without resulting in } \\
\text { a Category } 1 \text { or Category } 2 \text { event sequence. (BSC 2005b Section 5.1.7.4) } \\
\text { - Spurious or operator-induced opening of the WP shielded compartment followed by a } \\
\text { bedplate roll-out shall be precluded when the transporter is in motion. (BSC 2005b Section } \\
5.1 .7 .6 \text { ) } \\
\text { - Radiation exposure to workers due to inadvertent actuation of the WP transporter } \\
\text { shielded compartment doors shall be precluded such that this is not a Category } 1 \text { event. } \\
\text { (BSC 2005b Section 5.1.1.57) } \\
\text { - Upon a loss of power, the WP transporter shall be designed to stop, retain its load, and } \\
\text { enter a locked mode; upon a restoration of power, the WP transporter shall stay in the } \\
\text { locked mode until operator action is taken. (BSC 2005b Section 5.1.2.2) }\end{array}$ \\
\hline
\end{tabular}




\begin{tabular}{|c|c|c|c|c|}
\hline $\begin{array}{l}\text { System or } \\
\text { Subsystem }\end{array}$ & $\begin{array}{l}\text { Component } \\
\text { or Function }\end{array}$ & $\begin{array}{l}\text { ITS or } \\
\text { ITWI }\end{array}$ & $\begin{array}{l}\text { Safety } \\
\text { Category }\end{array}$ & Nuclear Safety Design Bases \\
\hline WP Emplacement & $\begin{array}{l}\text { WP Emplacement } \\
\text { Gantry }\end{array}$ & ITS & sc & 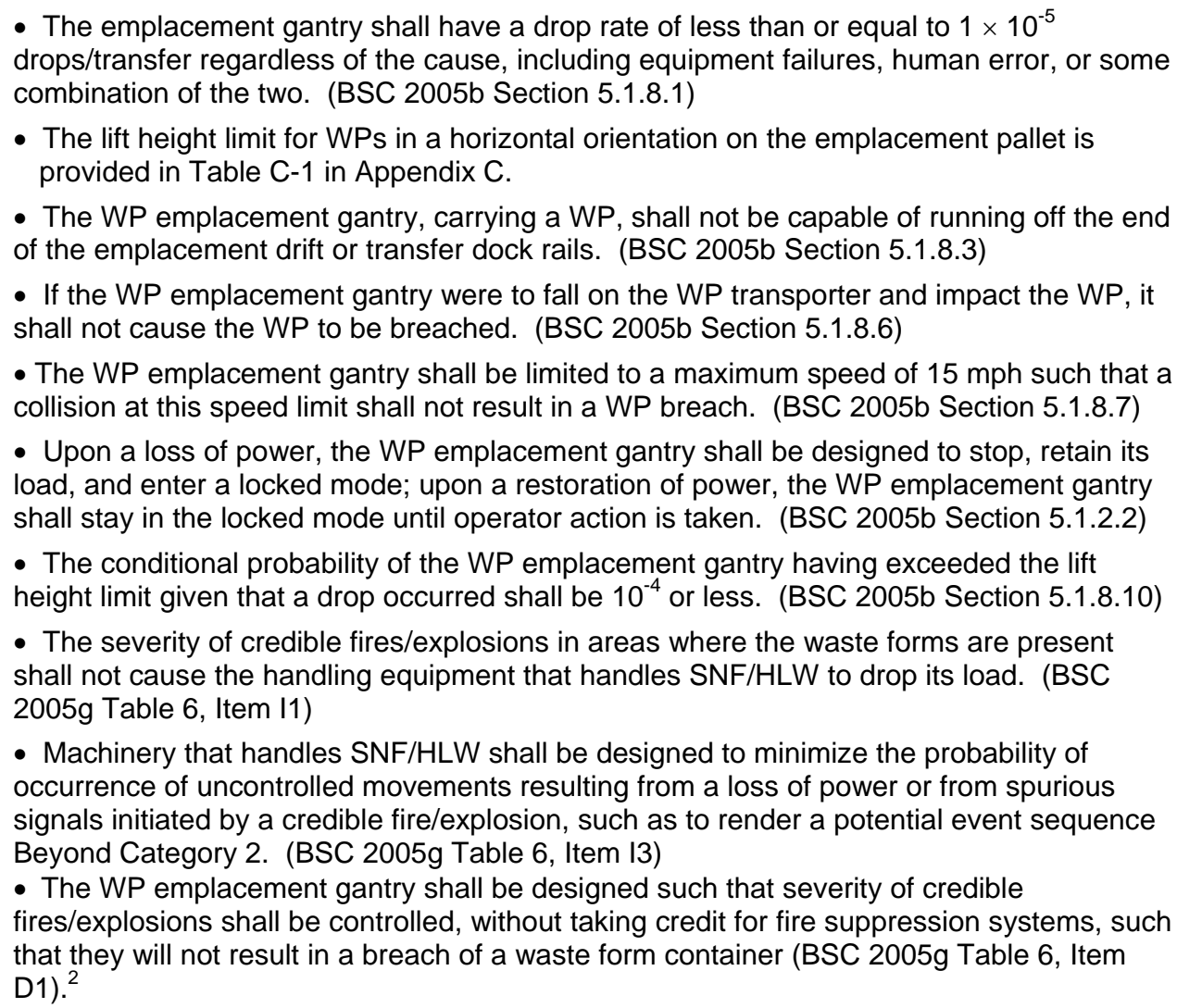 \\
\hline
\end{tabular}




\begin{tabular}{|c|c|c|c|c|}
\hline $\begin{array}{l}\text { System or } \\
\text { Subsystem }\end{array}$ & $\begin{array}{l}\text { Component } \\
\text { or Function }\end{array}$ & $\begin{array}{l}\text { ITS or } \\
\text { ITWI }\end{array}$ & $\begin{array}{l}\text { Safety } \\
\text { Category }\end{array}$ & Nuclear Safety Design Bases \\
\hline \multicolumn{5}{|r|}{ Fire Protection System } \\
\hline $\begin{array}{l}\text { Explosion } \\
\text { Protection }\end{array}$ & Entire & N/A & Non-SC & $\begin{array}{l}\text { Not applicable. None if the SSC functions associated with this subsystem are credited for } \\
\text { the prevention or mitigation of an event sequence. }\end{array}$ \\
\hline Fire Alarm & Entire & N/A & Non-SC & $\begin{array}{l}\text { Not applicable. None if the SSC functions associated with this subsystem are credited for } \\
\text { the prevention or mitigation of an event sequence. }\end{array}$ \\
\hline Fire Barriers & Entire & N/A & Non-SC & $\begin{array}{l}\text { Not applicable. None if the SSC functions associated with this subsystem are credited for } \\
\text { the prevention or mitigation of an event sequence. }\end{array}$ \\
\hline Fire Detection & Entire & N/A & Non-SC & $\begin{array}{l}\text { Not applicable. None if the SSC functions associated with this subsystem are credited for } \\
\text { the prevention or mitigation of an event sequence. }\end{array}$ \\
\hline \multirow[t]{2}{*}{ Fire Suppression } & $\begin{array}{l}\text { Manual Isolation } \\
\text { Valves Leading to } \\
\text { the Double- } \\
\text { Interlock Preaction } \\
\text { Sprinklers in } \\
\text { Moderator Control } \\
\text { Areas }\end{array}$ & ITS & SC & $\begin{array}{l}\text { Once closed by operator action, the manual isolation valves leading to the double-interlock } \\
\text { preaction sprinklers in moderator control areas shall be capable of preventing the } \\
\text { introduction of water to the sprinklers when fissile material is present. (BSC 2005b Section } \\
\text { 5.1.1.66) }\end{array}$ \\
\hline & $\begin{array}{l}\text { SSCs other than } \\
\text { Manual Isolation } \\
\text { Valves Leading to } \\
\text { the Double- } \\
\text { Interlock Preaction } \\
\text { Sprinklers in } \\
\text { Moderator Control } \\
\text { Areas }\end{array}$ & N/A & Non-SC & $\begin{array}{l}\text { Not applicable. None if the SSC functions associated with this subsystem are credited for } \\
\text { the prevention or mitigation of an event sequence. }\end{array}$ \\
\hline Fire Water & Entire & N/A & Non-SC & $\begin{array}{l}\text { Not applicable. None of the SSC functions associated with this subsystem are credited for } \\
\text { the prevention or mitigation of an event sequence. }\end{array}$ \\
\hline
\end{tabular}




\begin{tabular}{|l|l|l|l|l|}
\hline \multicolumn{1}{|c|}{$\begin{array}{c}\text { System or } \\
\text { Subsystem }\end{array}$} & \multicolumn{1}{|c|}{$\begin{array}{c}\text { Component } \\
\text { or Function }\end{array}$} & $\begin{array}{c}\text { ITS or } \\
\text { ITWI }\end{array}$ & $\begin{array}{c}\text { Safety } \\
\text { Category }\end{array}$ & Nuclear Safety Design Bases \\
\hline \multicolumn{3}{|c|}{ HVAC Plant Heating and Cooling System } \\
\hline $\begin{array}{l}\text { HVAC Plant } \\
\text { Heating and } \\
\text { Cooling }\end{array}$ & Entire & N/A & Non-SC & $\begin{array}{l}\text { Not applicable. None of the SSC functions associated with these subsystems are credited } \\
\text { for the prevention or mitigation of an event sequence. }\end{array}$ \\
\hline & N/A & Non-SC & $\begin{array}{l}\text { Not applicable. None of the SSC functions associated with these subsystems are credited } \\
\text { for the prevention or mitigation of an event sequence. }\end{array}$ \\
\hline $\begin{array}{l}\text { Low-Level } \\
\text { Radioactive Waste } \\
\text { Management }\end{array}$ & Entire & & \\
\hline & N/A & Non-SC & $\begin{array}{l}\text { Not applicable. None of the SSC functions associated with these subsystems are credited } \\
\text { for the prevention or mitigation of an event sequence. }\end{array}$ \\
\hline $\begin{array}{l}\text { Low-Level } \\
\text { Radioactive Waste } \\
\text { Generating }\end{array}$ & Entire & & \\
\hline
\end{tabular}


Table A-II. Nuclear Safety Design Bases of Systems and Subsystems

\begin{tabular}{|c|c|c|c|c|}
\hline $\begin{array}{l}\text { System or } \\
\text { Subsystem }\end{array}$ & $\begin{array}{l}\text { Component } \\
\text { or Function }\end{array}$ & $\begin{array}{l}\text { ITS or } \\
\text { ITWI }\end{array}$ & $\begin{array}{l}\text { Safety } \\
\text { Category }\end{array}$ & Nuclear Safety Design Bases \\
\hline \multicolumn{5}{|c|}{ Naval Spent Fuel Canister } \\
\hline $\begin{array}{l}\text { Naval SFC } \\
\text { Internals }\end{array}$ & $\begin{array}{l}\text { Naval SFC } \\
\text { Baskets, Naval } \\
\text { SNF Basket } \\
\text { Spacers, } \\
\text { Corrosion- } \\
\text { Resistant Cans; } \\
\text { Control Rods or } \\
\text { installed Hafnium } \\
\text { Neutron- } \\
\text { Absorbing } \\
\text { Assemblies and } \\
\text { their Neutron } \\
\text { Poison Retention } \\
\text { Devices; and } \\
\text { Naval SNF } \\
\text { Cladding }\end{array}$ & ITWI & SC & $\begin{array}{l}\text { This SSC is ITWI; no function of this SSC is credited for the prevention or mitigation of an } \\
\text { event sequence. }\end{array}$ \\
\hline Naval SFC & Naval SFC & $\begin{array}{l}\text { ITS } \\
\text { ITWI }\end{array}$ & SC & $\begin{array}{l}\text { - The naval SFC shall withstand fire conditions corresponding to a black body gas } \\
\text { exposure flux of } 50 \mathrm{~kW} / \mathrm{m}^{2} \text { and a temperature of } 1000^{\circ} \mathrm{C}\left(1832^{\circ} \mathrm{F}\right) \text { for } 2 \text { minutes (BSC } \\
2005 \mathrm{~g} \text { [DIRS 174263], Section 6.2.1.2.6). }\end{array}$ \\
\hline
\end{tabular}




\begin{tabular}{|c|c|c|c|c|}
\hline $\begin{array}{l}\text { System or } \\
\text { Subsystem }\end{array}$ & $\begin{array}{l}\text { Component } \\
\text { or Function }\end{array}$ & $\begin{array}{l}\text { ITS or } \\
\text { ITWI }\end{array}$ & $\begin{array}{l}\text { Safety } \\
\text { Category }\end{array}$ & Nuclear Safety Design Bases \\
\hline \multicolumn{5}{|c|}{ Naval Waste Package System } \\
\hline Naval WP & Waste Package & $\begin{array}{l}\text { ITS } \\
\text { ITWI }\end{array}$ & SC & $\begin{array}{l}\text { - Sealed naval WPs shall withstand without breaching the following drops: (BSC } 2005 \mathrm{~b} \\
\text { Section 5.1.3.12) } \\
\text { A. Free-drop of } 6.5 \mathrm{ft} \text { ( } 3.3 \mathrm{ft} \text { for the naval long WP) from a vertical orientation onto a } \\
\text { horizontal surface (trunnion collars installed) } \\
\text { B. Free-drop of } 7.8 \mathrm{ft} \text { from a horizontal orientation onto a horizontal surface (trunnion } \\
\text { collars installed) } \\
\text { C. Free-drop with the emplacement pallet from a horizontal orientation onto a horizontal } \\
\text { surface (trunnion collars not installed) of } 6.5 \mathrm{ft} \text { from the bottom of the emplacement } \\
\text { pallet } \\
\text { D. Tip-over onto a horizontal surface from a } 6.5 \mathrm{ft} \text { (1.6 ft for the naval long WP) elevated } \\
\text { surface (trunnion collars installed) } \\
\text { E. Tip-over onto the tilting machine, including contact with the trunnion cradles or the } \\
\text { floor (trunnion collars installed). } \\
\text { Note: Drop and tip-over event sequences shall be evaluated for worst possible (most } \\
\text { damaging) credible conditions including initial geometric position and weight of } \\
\text { contents. An unyielding, flat horizontal surface may be used to bound the } \\
\text { consequences of a drop. Drops shall include attendant swing-down and/or slap- } \\
\text { down from the indicated position, with or without trunnion collars attached, as } \\
\text { appropriate. }\end{array}$ \\
\hline
\end{tabular}




\begin{tabular}{|c|c|c|c|c|}
\hline $\begin{array}{l}\text { System or } \\
\text { Subsystem }\end{array}$ & $\begin{array}{l}\text { Component } \\
\text { or Function }\end{array}$ & $\begin{array}{l}\text { ITS or } \\
\text { ITWI }\end{array}$ & $\begin{array}{l}\text { Safety } \\
\text { Category }\end{array}$ & Nuclear Safety Design Bases \\
\hline $\begin{array}{l}\text { Naval WP } \\
\text { (continued) }\end{array}$ & $\begin{array}{l}\text { Waste Package } \\
\text { (continued) }\end{array}$ & $\begin{array}{l}\text { ITS } \\
\text { ITWI }\end{array}$ & SC & $\begin{array}{l}\text { - A naval WP in a horizontal orientation on the emplacement pallet shall be lifted in } \\
\text { accordance with the lift height limits in Table C-1 in Appendix C. } \\
\text { - A naval long WP in a vertical orientation shall be lifted in accordance with the lift height } \\
\text { limits in Table C-1 in Appendix C. } \\
\text { - Naval WPs shall withstand a single rockfall of } 1.2 \times 10^{5} \text { joules or less without breaching. } \\
\text { (BSC 2005b Section 6.3.6.1.20) } \\
\text { - Naval WPs shall withstand two consecutive rockfalls having a total kinetic energy of } \\
1.0 \times 10^{5} \text { joules or less without breaching. (BSC } 2005 \mathrm{~b} \text { Section } 6.3 .6 .1 .20 \text { ) } \\
\text { - Naval WPs shall be designed for loading conditions associated with a DBGM-2 seismic } \\
\text { event and to demonstrate sufficient margin to ensure that "no breach" and "no criticality" } \\
\text { safety functions }{ }^{3} \text { are maintained for loading conditions associated with a BDBGM seismic } \\
\text { event. (BSC } 2004 a \text { Table IV-1) } \\
\text { - Sealed naval WPs shall be designed such that drops, collisions, and other handling } \\
\text { impacts within the WP design bases (allowing for rearrangement of container internals, } \\
\text { proximity of other sealed WPs, and without credit for burnup) cannot lead to a nuclear } \\
\text { criticality. (BSC 2005b Section } 5.1 .3 .1 \text { ) } \\
\text { - The naval WP shall be designed such that it can be loaded with a naval SFC without } \\
\text { leading to a preclosure nuclear criticality with credit for moderator control. (BSC } 2005 b \\
\text { Section 5.1.3.2) } \\
\text { - An unsealed naval WP that is dropped from within } 2 \mathrm{ft} \text { above an essentially unyielding } \\
\text { flat surface shall not spill its contents. (BSC } 2005 b \text { Section } 5.1 .3 .11 \text { ) } \\
\text { - An unsealed naval WP containing a naval SFC shall be lifted in accordance with the lift } \\
\text { height limits in Table C-1 in Appendix C. }\end{array}$ \\
\hline & Trunnion Collar & ITS & sc & $\begin{array}{l}\text { - Trunnion collars shall be designed for loading conditions associated with a DBGM-2 } \\
\text { seismic event and to demonstrate sufficient seismic design margin to ensure that a "no } \\
\text { drop" safety function }{ }^{3} \text { is maintained for loading conditions associated with a BDBGM } \\
\text { seismic event. (BSC 2004a Table IV-1) }\end{array}$ \\
\hline
\end{tabular}




\begin{tabular}{|c|c|c|c|c|}
\hline $\begin{array}{l}\text { System or } \\
\text { Subsystem }\end{array}$ & $\begin{array}{l}\text { Component } \\
\text { or Function }\end{array}$ & $\begin{array}{l}\text { ITS or } \\
\text { ITWI }\end{array}$ & $\begin{array}{l}\text { Safety } \\
\text { Category }\end{array}$ & Nuclear Safety Design Bases \\
\hline \multicolumn{5}{|c|}{ Non-Nuclear Handling System } \\
\hline $\begin{array}{l}\text { Non-Nuclear } \\
\text { Handling }\end{array}$ & Entire & N/A & Non-SC & $\begin{array}{l}\text { Not applicable. None the SSC functions associated with these subsystems are credited for } \\
\text { the prevention or mitigation of an event sequence. }\end{array}$ \\
\hline \multicolumn{5}{|c|}{ Non-Radiological Waste Management System } \\
\hline $\begin{array}{l}\text { Non-Radiological } \\
\text { Waste } \\
\text { Management }\end{array}$ & Entire & N/A & Non-SC & $\begin{array}{l}\text { Not applicable. None of the SSC functions associated with these subsystems are credited } \\
\text { for the prevention or mitigation of an event sequence. }\end{array}$ \\
\hline \multicolumn{5}{|r|}{ Plant Services System } \\
\hline Plant Services & Entire & N/A & Non-SC & $\begin{array}{l}\text { Not applicable. None of the SSC functions associated with these subsystems are credited } \\
\text { for the prevention or mitigation of an event sequence. }\end{array}$ \\
\hline \multicolumn{5}{|c|}{ Radiation/Radiological Monitoring System } \\
\hline $\begin{array}{l}\text { Radiation/ } \\
\text { Radiological } \\
\text { Monitoring }\end{array}$ & Entire & N/A & Non-SC & $\begin{array}{l}\text { Not applicable. None of the SSC functions associated with these subsystems are credited } \\
\text { for the prevention or mitigation of an event sequence. }\end{array}$ \\
\hline \multicolumn{5}{|r|}{ Remediation System } \\
\hline Dry Remediation & $\begin{array}{l}\text { Trolleys, } \\
\text { Pedestals, and } \\
\text { Hold-Down } \\
\text { Devices }\end{array}$ & ITS & SC & $\begin{array}{l}\text { - Upon a loss of power, this trolley shall be designed to stop, retain its load, and enter a } \\
\text { locked mode; upon a restoration of power, this trolley shall stay in the locked mode until } \\
\text { operator action is taken. (BSC 2005b Section 5.1.2.2) }\end{array}$ \\
\hline
\end{tabular}




\begin{tabular}{|c|c|c|c|c|}
\hline $\begin{array}{l}\text { System or } \\
\text { Subsystem }\end{array}$ & $\begin{array}{l}\text { Component } \\
\text { or Function }\end{array}$ & $\begin{array}{l}\text { ITS or } \\
\text { ITWI }\end{array}$ & $\begin{array}{l}\text { Safety } \\
\text { Category }\end{array}$ & Nuclear Safety Design Bases \\
\hline $\begin{array}{l}\text { Dry Remediation } \\
\text { (continued) }\end{array}$ & $\begin{array}{l}\text { Trolleys, } \\
\text { Pedestals, and } \\
\text { Hold-Down } \\
\text { Devices } \\
\text { (continued) }\end{array}$ & ITS & SC & $\begin{array}{l}\text { - Pedestals and hold-down devices shall be designed for loading conditions associated } \\
\text { with a DBGM-2 seismic event and to demonstrate sufficient seismic design margin to } \\
\text { ensure that a "no tipover" safety function }{ }^{3} \text { is maintained for loading conditions associated } \\
\text { with a BDBGM seismic event. (BSC } 2004 a \text { Table IV-1) } \\
\text { - The trolley system shall be designed for loading conditions associated with a DBGM-2 } \\
\text { seismic event to maintain trolley stability and prevent waste container slapdown. In } \\
\text { addition, an analysis shall demonstrate that the trolley system has sufficient seismic design } \\
\text { margin to ensure that a "no slapdown" safety function is maintained for loading conditions } \\
\text { associated with a BDBGM seismic event. (BSC } 2004 a \text { Table IV-1) } \\
\text { - The trolley shall be designed with an inherent speed limit such that a collision at the } \\
\text { trolley speed limit would not cause the trolley to drop its load. (BSC 2005b Section } \\
\text { 5.1.1.61) } \\
\text { - Loaded transfer trolleys shall not derail or drop their loads. (BSC 2005b Section } \\
\text { 5.1.1.36) } \\
\text { - The severity of credible fires/explosions in areas where the waste forms are present } \\
\text { shall not cause the handling equipment that handles SNF/HLW to drop its load. (BSC } \\
2005 g \text { Table } 6 \text {, Item I1) } \\
\text { - Machinery that handles SNF/HLW shall be designed to minimize the probability of } \\
\text { occurrence of uncontrolled movements resulting from a loss of power or from spurious } \\
\text { signals initiated by a credible fire/explosion, such as to render a potential event sequence } \\
\text { Beyond Category 2. (BSC } 2005 \mathrm{~g} \text { Table } 6 \text {, Item I3) }\end{array}$ \\
\hline & Turntable & ITS & SC & $\begin{array}{l}\text { - The turntable system shall be designed for loading conditions associated with a DBGM-2 } \\
\text { seismic event to maintain turntable stability and prevent waste container tipover. In } \\
\text { addition, an analysis shall demonstrate that the turntable system has sufficient seismic } \\
\text { design margin to ensure that a "no tipover" safety function }{ }^{3} \text { is maintained for loading } \\
\text { conditions associated with a BDBGM seismic event. (BSC 2004a Table IV-1) }\end{array}$ \\
\hline
\end{tabular}




\begin{tabular}{|c|c|c|c|c|}
\hline $\begin{array}{l}\text { System or } \\
\text { Subsystem }\end{array}$ & $\begin{array}{l}\text { Component } \\
\text { or Function }\end{array}$ & $\begin{array}{l}\text { ITS or } \\
\text { ITWI }\end{array}$ & $\begin{array}{l}\text { Safety } \\
\text { Category }\end{array}$ & Nuclear Safety Design Bases \\
\hline \multirow[t]{3}{*}{$\begin{array}{l}\text { Dry Remediation } \\
\text { (continued) }\end{array}$} & $\begin{array}{l}\text { Turntable } \\
\text { (continued) }\end{array}$ & ITS & SC & $\begin{array}{l}\text { - The severity of credible fires/explosions in areas where the waste forms are present } \\
\text { shall not cause the handling equipment that handles SNF/HLW to drop its load. (BSC } \\
2005 \mathrm{~g} \text { Table } 6 \text {, Item I1) } \\
\text { - Machinery that handles SNF/HLW shall be designed to minimize the probability of } \\
\text { occurrence of uncontrolled movements resulting from a loss of power or from spurious } \\
\text { signals initiated by a credible fire/explosion, such as to render a potential event sequence } \\
\text { Beyond Category 2. (BSC } 2005 \mathrm{~g} \text { Table } 6 \text {, Item I3) }\end{array}$ \\
\hline & Fuel Container & ITS & SC & $\begin{array}{l}\text { - The fuel container shall be designed to ensure nuclear criticality safety with optimum } \\
\text { moderation and the most reactive waste forms. Criticality safety will be maintained despite } \\
\text { geometric rearrangements due to a drop or other handling incidents. (BSC 2005b Section } \\
\text { 5.1.1.4) }\end{array}$ \\
\hline & Docking Station & ITS & SC & $\begin{array}{l}\text { - A drop or collision involving components associated with a docking port shall not breach } \\
\text { the lid of a transportation cask or site-specific cask situated at the docking port. (BSC } \\
\text { 2005b Section 5.1.1.17) }\end{array}$ \\
\hline
\end{tabular}




\begin{tabular}{|c|c|c|c|c|}
\hline $\begin{array}{l}\text { System or } \\
\text { Subsystem }\end{array}$ & $\begin{array}{l}\text { Component } \\
\text { or Function }\end{array}$ & $\begin{array}{l}\text { ITS or } \\
\text { ITWI }\end{array}$ & $\begin{array}{l}\text { Safety } \\
\text { Category }\end{array}$ & Nuclear Safety Design Bases \\
\hline \multirow[t]{2}{*}{ Wet Remediation } & $\begin{array}{l}\text { Cask Handling } \\
\text { Crane; } \\
200 \text { ton }\end{array}$ & ITS & SC & $\begin{array}{l}\text { - The drop rate for cranes involved in handling waste forms and their associated } \\
\text { containers shall be less than or equal to } 1 \times 10^{-5} \text { drops/transfer, regardless of cause, } \\
\text { including human error, failure of equipment such as yokes and grapples, or a combination } \\
\text { of the two. (BSC } 2005 \mathrm{~b} \text { Section } 5.1 .1 .10 \text { ) } \\
\text { - Upon a loss of power, this crane shall be designed to stop, retain its load, and enter a } \\
\text { locked mode; upon a restoration of power, this crane shall stay in the locked mode until } \\
\text { operator action is taken. (BSC } 2005 \mathrm{~b} \text { Section } 5.1 .2 .1 \text { ) } \\
\text { - The conditional probability of the crane exceeding a lift-height limit, given that a drop has } \\
\text { occurred, shall be less than or equal to } 1 \times 10^{-4} \text {. (BSC } 2005 \mathrm{~b} \text { Section } 5.1 .1 .12 \text { ) } \\
\text { - The lift height limit for transportation casks without impact limiters or site-specific } \\
\text { casks is provided in Table C-1 of Appendix C. } \\
\text { - This crane and its rigging shall be designed for loading conditions associated with a } \\
\text { DBGM-2 seismic event and to demonstrate sufficient seismic design margin to ensure that } \\
\text { a "no drop" safety function }{ }^{3} \text { is maintained for loading conditions associated with a BDBGM } \\
\text { seismic event. (BSC } 2004 \text { a Table IV-1) } \\
\text { - This crane shall not be capable of moving above a speed limit for overhead crane } \\
\text { transfers such that a collision at the speed limit would not breach a transportation cask or } \\
\text { site-specific cask. (BSC } 2005 \mathrm{~b} \text { Section 5.1.1.19) }\end{array}$ \\
\hline & $\begin{array}{l}\text { Cask Handling } \\
\text { Crane; } \\
200 \text { ton } \\
\text { (continued) }\end{array}$ & ITS & SC & $\begin{array}{l}\text { - This crane shall not be capable of exerting sufficient force during transfer to breach a } \\
\text { cask as the result of attempts to overcome mechanical constraints. (BSC 2005b Section } \\
5.1 .1 .20 \text { ) } \\
\text { - The severity of credible fires/explosions in areas where the waste forms are present } \\
\text { shall not cause the handling equipment that handles SNF/HLW to drop its load. (BSC } \\
2005 \mathrm{~g} \text { Table 6, Item I1) } \\
\text { - Cranes and other machinery that handle SNF/HLW shall be designed to minimize the } \\
\text { probability of occurrence of uncontrolled movements resulting from a loss of power or from } \\
\text { spurious signals initiated by a credible fire/explosion, such as to render a potential event } \\
\text { sequence Beyond Category 2. (BSC } 2005 \mathrm{~g} \text { Table 6, Item I3) }\end{array}$ \\
\hline
\end{tabular}




\begin{tabular}{|c|c|c|c|c|}
\hline $\begin{array}{l}\text { System or } \\
\text { Subsystem }\end{array}$ & $\begin{array}{l}\text { Component } \\
\text { or Function }\end{array}$ & $\begin{array}{l}\text { ITS or } \\
\text { ITWI }\end{array}$ & $\begin{array}{l}\text { Safety } \\
\text { Category }\end{array}$ & Nuclear Safety Design Bases \\
\hline \multirow[t]{4}{*}{$\begin{array}{l}\text { Wet Remediation } \\
\text { (continued) }\end{array}$} & Pit Crush Pad & ITS & SC & $\begin{array}{l}\text { - Crush pads shall limit the impact energy of a dropped canister, cask, or WP to be less } \\
\text { than or equal to the impact energy associated with a drop of a cask or WP onto an } \\
\text { unyielding surface from their maximum specified drop height for the cask or WP }{ }^{6} \text {. (BSC } \\
\text { 2005b Sections 5.1.1.18, 5.1.3.9, and 5.1.1.52) }\end{array}$ \\
\hline & Pool Crush Pad & ITS & $\mathrm{SC}$ & $\begin{array}{l}\text { - Crush pads shall limit the impact energy of a dropped cask to be less than or equal to } \\
\text { the impact energy associated with a drop of a cask onto an unyielding surface from their } \\
\text { maximum specified drop height for the cask }{ }^{6} \text {. (BSC 2005b Sections 5.1.1.18) }\end{array}$ \\
\hline & Turntable & $\mathrm{N} / \mathrm{A}$ & Non-SC & $\begin{array}{l}\text { Not applicable. No function of this SSC is credited for the prevention or mitigation of an } \\
\text { event sequence. }\end{array}$ \\
\hline & $\begin{array}{l}\text { Fuel Handling } \\
\text { Machine and } \\
\text { Grapples }\end{array}$ & ITS & SC & $\begin{array}{l}\text { - The fuel handling machine and grapples shall be designed for loading conditions } \\
\text { associated with a DBGM-2 seismic event and demonstrate sufficient seismic design } \\
\text { margin to a "maintain waste form" safety function }{ }^{3} \text {. (BSC } 2004 \text { a Table IV-1, BSC } 2005 \mathrm{~b} \\
\text { Section 5.1.2.10) } \\
\text { - The fuel handling machine and grapples shall be designed for loading conditions } \\
\text { associated with a DBGM-2 seismic event and to demonstrate sufficient seismic design } \\
\text { margin to ensure that a "no fall down" safety function }{ }^{3} \text { is maintained for loading conditions } \\
\text { associated with a BDBGM seismic event. (BSC } 2004 \text { a Table IV-1) } \\
\text { - The fuel handling machine shall have a drop rate of less than or equal to } 1 \times 10^{-5} \\
\text { drops/transfer, including transfers in single-assembly canisters. (BSC } 2005 \mathrm{~b} \text { Section } \\
5.1 .1 .7 \text { ) }\end{array}$ \\
\hline
\end{tabular}




\begin{tabular}{|c|c|c|c|c|}
\hline $\begin{array}{l}\text { System or } \\
\text { Subsystem }\end{array}$ & $\begin{array}{l}\text { Component } \\
\text { or Function }\end{array}$ & $\begin{array}{l}\text { ITS or } \\
\text { ITWI }\end{array}$ & $\begin{array}{l}\text { Safety } \\
\text { Category }\end{array}$ & Nuclear Safety Design Bases \\
\hline $\begin{array}{l}\text { Wet Remediation } \\
\text { (continued) }\end{array}$ & $\begin{array}{l}\text { Fuel Handling } \\
\text { Machine and } \\
\text { Grapples } \\
\text { (continued) }\end{array}$ & ITS & SC & $\begin{array}{l}\text { - The rate of assembly collisions during an assembly transfer operation shall be less than } \\
\text { or equal to } 1 \times 10^{-5} \text { collisions/transfer. (BSC } 2005 \mathrm{~b} \text { Section } 5.1 .1 .8 \text { ) } \\
\text { - The probability of a drop of handling equipment onto a commercial SNF assembly with } \\
\text { enough energy to breach the assembly shall be less than or equal to } 1 \times 10^{-7} \\
\text { impacts/transfer for each assembly transferred. (BSC } 2005 \mathrm{~b} \text { Section } 5.1 .1 .9 \text { ) } \\
\text { - The fuel handling machine shall not be capable of lateral movements of handling } \\
\text { equipment at a speed that could breach a commercial SNF assembly as a result of the } \\
\text { collision of handling equipment against an SNF assembly. (BSC } 2005 \mathrm{~b} \text { Section } 5.1 .1 .54 \text { ) } \\
\text { - Upon a loss of power, the fuel handling machine shall be designed to stop, retain its } \\
\text { load, and enter a locked mode; upon a restoration of power, this machine shall stay in the } \\
\text { locked mode until operator action is taken. (BSC } 2005 \mathrm{~b} \text { Section } 5.1 .2 .1 \text { ) } \\
\text { - The severity of credible fires/explosions in areas where the waste forms are present } \\
\text { shall not cause the handling equipment that handles SNF/HLW to drop its load. (BSC } \\
2005 \mathrm{~g} \text { Table } 6 \text {, Item I1) } \\
\text { - Cranes and other machinery that handle SNF/HLW shall be designed to minimize the } \\
\text { probability of occurrence of uncontrolled movements resulting from a loss of power or from } \\
\text { spurious signals initiated by a credible fire/explosion, such as to render a potential event } \\
\text { sequence Beyond Category } 2 \text {. (BSC } 2005 \mathrm{~g} \text { Table } 6 \text {, Item I3) } \\
\text { - Commercial SNF assemblies shall be lifted less than } 28 \mathrm{ft} \text { above an essentially } \\
\text { unyielding surface. (BSC } 2005 \mathrm{~b} \text { Section } 5.1 .1 .46 \text { ) }\end{array}$ \\
\hline
\end{tabular}




\begin{tabular}{|c|c|c|c|c|}
\hline $\begin{array}{l}\text { System or } \\
\text { Subsystem }\end{array}$ & $\begin{array}{l}\text { Component } \\
\text { or Function }\end{array}$ & $\begin{array}{l}\text { ITS or } \\
\text { ITWI }\end{array}$ & $\begin{array}{l}\text { Safety } \\
\text { Category }\end{array}$ & Nuclear Safety Design Bases \\
\hline \multirow[t]{2}{*}{$\begin{array}{l}\text { Wet Remediation } \\
\text { (continued) }\end{array}$} & $\begin{array}{l}\text { Crane Lifting } \\
\text { Yokes }\end{array}$ & ITS & SC & $\begin{array}{l}\text { - The crane lifting yokes shall be designed for loading conditions associated with a DBGM- } \\
2 \text { seismic event. In addition, an analysis shall demonstrate that the crane lifting yokes } \\
\text { have sufficient seismic design margin to ensure that a "no drop" safety function }{ }^{3} \text { is } \\
\text { maintained for loading conditions associated with a BDBGM seismic event. (BSC 2004a } \\
\text { Table IV-1) }\end{array}$ \\
\hline & $\begin{array}{l}\text { Staging } \\
\text { Racks/Baskets in } \\
\text { Remediation Pool }\end{array}$ & ITS & SC & $\begin{array}{l}\text { - The staging racks shall be designed for loading conditions associated with a DBGM-2 } \\
\text { seismic event for stability and distortion such as to maintain assembly geometry in the } \\
\text { rack. In addition, analyses shall demonstrate that the staging racks/baskets have sufficient } \\
\text { seismic design margin to ensure that distortion of the racks/baskets is limited and stability } \\
\text { is maintained for loading conditions associated with a BDBGM seismic event. (BSC 2004a } \\
\text { Table IV-1) } \\
\text { - Fully loaded baskets in staging racks shall be subcritical when fully flooded with pure } \\
\text { water (i.e., no credit for neutron absorbers dissolved in the water); the baskets shall have } \\
\text { sufficient criticality controls to remain subcritical under the expected range of conditions } \\
\text { resulting from handling incidents in and out of staging racks; and the baskets shall be } \\
\text { closed during handling such that a closed basket being transferred in the pool will not spill } \\
\text { SNF assemblies into the pool if the basket is dropped. (BSC 2005b Section 5.1.5.9) }\end{array}$ \\
\hline
\end{tabular}




\begin{tabular}{|c|c|c|c|c|}
\hline $\begin{array}{l}\text { System or } \\
\text { Subsystem }\end{array}$ & $\begin{array}{l}\text { Component } \\
\text { or Function }\end{array}$ & $\begin{array}{l}\text { ITS or } \\
\text { ITWI }\end{array}$ & $\begin{array}{c}\text { Safety } \\
\text { Category }\end{array}$ & Nuclear Safety Design Bases \\
\hline WP Remediation & $\begin{array}{l}\text { WP Remediation } \\
\text { Crane; } 100 \text { ton }\end{array}$ & ITS & SC & $\begin{array}{l}\text { - The drop rate for cranes involved in handling waste forms and their associated } \\
\text { containers shall be less than or equal to } 1 \times 10^{-5} \text { drops/transfer, regardless of cause, } \\
\text { including human error, failure of equipment such as yokes and grapples, or a combination } \\
\text { of the two. (BSC 2005b Section } 5.1 .1 .10 \text { ) } \\
\text { - The probability of dropping handling equipment from a crane onto a canister shall be } \\
\text { less than or equal to } 1 \times 10^{-5} \text { for each canister transferred. (BSC } 2005 b \text { Section 5.1.1.11) } \\
\text { - Upon a loss of power, this crane shall be designed to stop, retain its load, and enter a } \\
\text { locked mode; upon a restoration of power, this crane shall stay in the locked mode until } \\
\text { operator action is taken. (BSC } 2005 b \text { Section } 5.1 .2 .1 \text { ) } \\
\text { - The conditional probability of the crane exceeding a lift-height limit, given that a drop has } \\
\text { occurred, shall be less than or equal to } 1 \times 10^{-4} \text {. (BSC 2005b Section 5.1.1.12) } \\
\text { - The lift height limits for the WPs, SNF assemblies, and canisters handled by this crane } \\
\text { are provided in Table C-1 in Appendix C; these WPS, SNF assemblies, and canisters } \\
\text { include: } \\
\text { 1. Sealed WPs containing commercial SNF, standardized DOE canisters, DOE HLW } \\
\text { canisters, naval SNF canisters, or DOE MCOs. } \\
\text { 2. Unsealed, loaded WPs containing commercial SNF, standardized DOE canisters, } \\
\text { DOE HLW canisters, naval SNF canisters, or DOE MCOs. } \\
\text { 3. Standardized DOE SNF canisters, DOE HLW canisters, DOE MCOs, sealed } \\
\text { vertical DPCs, or unsealed vertical DPCs. } \\
\text { 4. Commercial SNF assemblies. } \\
\text { - This crane system shall be designed for loading conditions associated with a DBGM-2 } \\
\text { seismic event and maintain its load. In addition, an analysis shall demonstrate that this } \\
\text { crane system has sufficient seismic design margin to ensure that a "no drop" safety } \\
\text { function is maintained for loading conditions associated with a BDBGM seismic event. } \\
\text { (BSC 2004a Table IV-1) }\end{array}$ \\
\hline
\end{tabular}




\begin{tabular}{|c|c|c|c|c|}
\hline $\begin{array}{l}\text { System or } \\
\text { Subsystem }\end{array}$ & $\begin{array}{l}\text { Component } \\
\text { or Function }\end{array}$ & $\begin{array}{l}\text { ITS or } \\
\text { ITWI }\end{array}$ & $\begin{array}{l}\text { Safety } \\
\text { Category }\end{array}$ & Nuclear Safety Design Bases \\
\hline $\begin{array}{l}\text { WP Remediation } \\
\text { (continued) }\end{array}$ & $\begin{array}{l}\text { WP Remediation } \\
\text { Crane;100 ton } \\
\text { (continued) }\end{array}$ & ITS & SC & $\begin{array}{l}\text { - This crane shall not be capable of moving above a speed limit for overhead crane } \\
\text { transfers such that a collision at the speed limit would not breach a loaded sealed WP, a } \\
\text { DOE MCO, a standardized DOE SNF canister, a DOE HLW canister, or a DPC. (BSC } \\
2005 b \text { Section 5.1.1.19) } \\
\text { - This crane shall not be capable of exerting sufficient force to breach a WP or a canister } \\
\text { as the result of attempts to overcome mechanical constraints. (BSC 2005b Section } \\
5.1 .1 .20 \text { ) } \\
\text { - This crane, which can be used to transfer SNF assemblies, shall not be capable of } \\
\text { lateral movements of handling equipment at a speed that could breach a commercial SNF } \\
\text { assembly as a result of the collision of handling equipment against an SNF assembly. } \\
\text { (BSC 2005b Section 5.1.1.54) } \\
\text { - The severity of credible fires/explosions in areas where the waste forms are present } \\
\text { shall not cause the handling equipment that handles SNF/HLW to drop its load. (BSC } \\
2005 g \text { Table 6, Item I1) } \\
\text { - Cranes and other machinery that handle SNF/HLW shall be designed to minimize the } \\
\text { probability of occurrence of uncontrolled movements resulting from a loss of power or from } \\
\text { spurious signals initiated by a credible fire/explosion, such as to render a potential event } \\
\text { sequence Beyond Category 2. (BSC } 2005 \mathrm{~g} \text { Table 6, Item I3) }\end{array}$ \\
\hline & $\begin{array}{l}\text { Crane Lifting } \\
\text { Yokes }\end{array}$ & ITS & SC & $\begin{array}{l}\text { - Crane lifting yokes shall be designed for loading conditions associated with a DBGM-2 } \\
\text { seismic event and to demonstrate sufficient seismic design margin to ensure that a "no } \\
\text { drop" safety function }{ }^{3} \text { is maintained for loading conditions associated with a BDBGM } \\
\text { seismic event. (BSC 2004a Table IV-1) }\end{array}$ \\
\hline
\end{tabular}




\begin{tabular}{|c|c|c|c|c|}
\hline $\begin{array}{l}\text { System or } \\
\text { Subsystem }\end{array}$ & $\begin{array}{l}\text { Component } \\
\text { or Function }\end{array}$ & $\begin{array}{l}\text { ITS or } \\
\text { ITWI }\end{array}$ & $\begin{array}{l}\text { Safety } \\
\text { Category }\end{array}$ & Nuclear Safety Design Bases \\
\hline \multirow[t]{2}{*}{$\begin{array}{l}\text { WP Remediation } \\
\text { (continued) }\end{array}$} & $\begin{array}{l}\text { WP Cutting } \\
\text { Machine }\end{array}$ & ITS & SC & $\begin{array}{l}\text { - The design of the WP cutting machine shall ensure that the mass, potential drop height, } \\
\text { and other characteristics of the WP cutting machine shall be such that a radiological } \\
\text { release will not result should the WP cutting machine fall onto or collide with the WP on } \\
\text { approach, during cutting, or on withdrawal. (BSC 2005b Section 5.1.5.11) } \\
\text { - The WP cutting machine shall preclude a radiological release due to damage inflicted } \\
\text { upon the WP contents during the lid cutting process. (BSC 2005b Section 5.1.5.2) } \\
\text { - The WP cutting machine shall be designed for loading conditions associated with a } \\
\text { DBGM-2 seismic event and to demonstrate sufficient seismic design margin to ensure that } \\
\text { "no failure" and "no fall down" safety functions }{ }^{3} \text { are maintained for loading conditions } \\
\text { associated with a BDBGM seismic event }{ }^{7} \text {. (BSC 2004a Table IV-1) } \\
\text { - The WP cutting machine shall be designed such that impacts to a WP that result in a } \\
\text { rearrangement of fissile material that may occur do not lead to a criticality. (BSC 2005b } \\
\text { Section 5.1.5.11) }\end{array}$ \\
\hline & $\begin{array}{l}\text { WP/DPC Trolleys, } \\
\text { Pedestals, and } \\
\text { Hold-Down } \\
\text { Devices }\end{array}$ & ITS & SC & $\begin{array}{l}\text { - Upon a loss of power, this trolley shall be designed to stop, retain its load, and enter a } \\
\text { locked mode; upon a restoration of power, this trolley shall stay in the locked mode until } \\
\text { operator action is taken. (BSC 2005b Section 5.1.2.2) } \\
\text { - The trolley system shall be designed for loading conditions associated with a DBGM-2 } \\
\text { seismic event to maintain trolley stability and prevent waste container slapdown. In } \\
\text { addition, an analysis shall demonstrate that the trolley system has sufficient seismic design } \\
\text { margin to ensure that a "no slapdown" safety function is maintained for loading conditions } \\
\text { associated with a BDBGM seismic event. (BSC 2004a Table IV-1) }\end{array}$ \\
\hline
\end{tabular}




\begin{tabular}{|c|c|c|c|c|}
\hline $\begin{array}{l}\text { System or } \\
\text { Subsystem }\end{array}$ & $\begin{array}{l}\text { Component } \\
\text { or Function }\end{array}$ & $\begin{array}{l}\text { ITS or } \\
\text { ITWI }\end{array}$ & $\begin{array}{l}\text { Safety } \\
\text { Category }\end{array}$ & Nuclear Safety Design Bases \\
\hline $\begin{array}{l}\text { WP Remediation } \\
\text { (continued) }\end{array}$ & $\begin{array}{l}\text { WP/DPC Trolleys, } \\
\text { Pedestals, and } \\
\text { Hold-Down } \\
\text { Devices } \\
\text { (continued) }\end{array}$ & ITS & SC & $\begin{array}{l}\text { - Pedestals and hold-down devices shall be designed for loading conditions associated } \\
\text { with a DBGM-2 seismic event and to demonstrate sufficient seismic design margin to } \\
\text { ensure that a "no tipover" safety function }{ }^{3} \text { is maintained for loading conditions associated } \\
\text { with a BDBGM seismic event. (BSC } 2004 \text { a Table IV-1) } \\
\text { - The trolley shall be designed with an inherent speed limit such that a collision at the } \\
\text { trolley speed limit would not cause the trolley to drop its load. (BSC } 2005 \mathrm{~b} \text { Section } \\
5.1 .1 .61 \text { ) } \\
\text { - Loaded transfer trolleys shall not derail or drop their loads. (BSC 2005b Section } \\
5.1 .1 .36 \text { ) } \\
\text { - The severity of credible fires/explosions in areas where the waste forms are present } \\
\text { shall not cause the handling equipment that handles SNF/HLW to drop its load. (BSC } \\
2005 \mathrm{~g} \text { Table } 6 \text {, Item I1) } \\
\text { - Machinery that handles SNF/HLW shall be designed to minimize the probability of } \\
\text { occurrence of uncontrolled movements resulting from a loss of power or from spurious } \\
\text { signals initiated by a credible fire/explosion, such as to render a potential event sequence } \\
\text { Beyond Category 2. (BSC } 2005 \mathrm{~g} \text { Table } 6 \text {, Item I3) }\end{array}$ \\
\hline \multicolumn{5}{|c|}{ Safeguards and Security System } \\
\hline $\begin{array}{l}\text { Safeguards and } \\
\text { Security }\end{array}$ & Entire & $\mathrm{N} / \mathrm{A}$ & Non-SC & $\begin{array}{l}\text { Not applicable. None of the SSC functions associated with these subsystems are credited } \\
\text { for the prevention or mitigation of an event sequence. }\end{array}$ \\
\hline
\end{tabular}




\begin{tabular}{|l|l|l|l|l|}
\hline $\begin{array}{c}\text { System or } \\
\text { Subsystem }\end{array}$ & $\begin{array}{c}\text { Component } \\
\text { or Function }\end{array}$ & $\begin{array}{c}\text { ITS or } \\
\text { ITWI }\end{array}$ & $\begin{array}{l}\text { Safety } \\
\text { Category }\end{array}$ & \multicolumn{2}{|c|}{ Nuclear Safety Design Bases } \\
\hline SNF Aging System \\
\hline Cask Transfer & Cask Tractor & ITS & SC & $\begin{array}{l}\text { - The cask tractor shall be limited in speed, including stopping and preventing runaway } \\
\text { situations, such that a site-specific cask being transported remains well within its design } \\
\text { tolerances. (BSC 2005b Section 5.1.11.2) } \\
\text { - The severity of credible fires/explosions in areas where the waste forms are present } \\
\text { shall not cause the handling equipment that handles SNF/HLW to drop its load. (BSC } \\
\text { 2005g Table 6, Item I1) } \\
\text { - Machinery that handles SNF/HLW shall be designed to minimize the probability of } \\
\text { occurrence of uncontrolled movements resulting from a loss of power or from spurious } \\
\text { signals initiated by a credible fire/explosion, such as to render a potential event sequence } \\
\text { Beyond Category 2. (BSC 2005g Table 6, Item I3) } \\
\text { - The cask tractor system shall be designed to prevent runaway of the tractor under } \\
\text { loading conditions associated with a DBGM-2 seismic event. In addition, an analysis shall } \\
\text { demonstrate that the cask tractor system has sufficient seismic design margin to ensure } \\
\text { that a "no runaway" safety function is maintained for loading conditions associated with a } \\
\text { BDBGM seismic event. (BSC 2004a Table IV-1) }\end{array}$ \\
\end{tabular}




\begin{tabular}{|c|c|c|c|c|}
\hline $\begin{array}{l}\text { System or } \\
\text { Subsystem }\end{array}$ & $\begin{array}{l}\text { Component } \\
\text { or Function }\end{array}$ & $\begin{array}{l}\text { ITS or } \\
\text { ITWI }\end{array}$ & $\begin{array}{l}\text { Safety } \\
\text { Category }\end{array}$ & Nuclear Safety Design Bases \\
\hline $\begin{array}{l}\text { Cask Transfer } \\
\text { (continued) }\end{array}$ & $\begin{array}{l}\text { Horizontal Cask } \\
\text { Transfer Trailer }\end{array}$ & ITS & SC & $\begin{array}{l}\text { - The design of the hydraulic ram shall ensure that it does not puncture a waste form that } \\
\text { is being placed into or removed from a HAM. (BSC 2005b Section 5.1.11.6) } \\
\text { - The horizontal cask transfer trailer system shall be designed for stability and to retain the } \\
\text { waste container and prevent a runaway for loading conditions associated with a DBGM-2 } \\
\text { seismic event. In addition, an analysis shall demonstrate that the horizontal cask transfer } \\
\text { trailer has sufficient seismic design margin to ensure that "no slapdown" and "no runaway" } \\
\text { safety functions }{ }^{3} \text { are maintained for loading conditions associated with a BDBGM seismic } \\
\text { event. (BSC 2004a Table IV-1) } \\
\text { - A means to limit speed for the transfer trailer, including stopping and preventing runaway } \\
\text { situations, shall be established such that a transfer cask being transported remains well } \\
\text { within its design tolerances. (BSC } 2005 \text { b Section 5.1.11.2) } \\
\text { - The horizontal cask transfer trailer shall prevent release by protecting the load following } \\
\text { a tipover or a collision with an object, including mobile and stationary structures, vehicles, } \\
\text { and other types of waste transfer conveyances. (BSC 2005b Section } 5.1 .11 .3 \text { ) } \\
\text { - The horizontal cask transfer trailer shall be designed such that severity of credible } \\
\text { fires/explosions shall be controlled, without taking credit for fire suppression systems, such } \\
\text { that they will not result in a breach of a waste form container (BSC 2005g Table } 6 \text {, Item } \\
\text { D1). }\end{array}$ \\
\hline
\end{tabular}




\begin{tabular}{|c|c|c|c|c|}
\hline $\begin{array}{l}\text { System or } \\
\text { Subsystem }\end{array}$ & $\begin{array}{l}\text { Component } \\
\text { or Function }\end{array}$ & $\begin{array}{l}\text { ITS or } \\
\text { ITWI }\end{array}$ & $\begin{array}{l}\text { Safety } \\
\text { Category }\end{array}$ & Nuclear Safety Design Bases \\
\hline $\begin{array}{l}\text { Cask Transfer } \\
\text { (continued) }\end{array}$ & $\begin{array}{l}\text { Site-Specific Cask } \\
\text { Transporter }\end{array}$ & ITS & SC & $\begin{array}{l}\text { - The site-specific cask transporter system shall be designed for stability and to retain the } \\
\text { waste container and prevent a runaway for loading conditions associated with a DBGM-2 } \\
\text { seismic event. In addition, an analysis shall demonstrate that the site-specific cask } \\
\text { transporter system has sufficient seismic design margin to ensure that "no slapdown" and } \\
\text { "no runaway" safety functions }{ }^{3} \text { are maintained for loading conditions associated with a } \\
\text { BDBGM seismic event. (BSC } 2004 \text { a Table IV-1) } \\
\text { - A speed limit for the site-specific cask transporter shall be established such that a } \\
\text { collision with shield or airlock doors or other heavy objects does not overturn the site- } \\
\text { specific cask transporter or cause it to drop its load. (BSC 2005b Section 5.1.1.38) } \\
\text { - A means to limit speed for the site-specific cask transporter, including stopping and } \\
\text { preventing runaway situations, shall be established such that a site-specific cask remains } \\
\text { well within its design tolerances. (BSC 2005b Section 5.1.11.2) } \\
\text { - The site-specific cask transporter shall prevent release by protecting the load following a } \\
\text { tipover or a collision with an object, including mobile and stationary structures, vehicles, } \\
\text { and other types of waste transfer conveyances. (BSC 2005b Section } 5.1 .11 .3 \text { ) } \\
\text { - Upon a loss of power, this transporter shall be designed to stop, retain its load, and enter } \\
\text { a locked mode; upon a restoration of power, this transporter shall stay in the locked mode } \\
\text { until operator action is taken. (BSC } 2005 b \text { Section } 5.1 .2 .2 \text { ) } \\
\text { - The site-specific cask transporter shall be designed such that severity of credible } \\
\text { fires/explosions shall be controlled, without taking credit for fire suppression systems, such } \\
\text { that they will not result in a breach of a waste form container (BSC } 2005 \mathrm{~g} \text { Table } 6 \text {, Item } \\
\text { D1). }\end{array}$ \\
\hline
\end{tabular}




\begin{tabular}{|c|c|c|c|c|}
\hline $\begin{array}{l}\text { System or } \\
\text { Subsystem }\end{array}$ & $\begin{array}{l}\text { Component } \\
\text { or Function }\end{array}$ & $\begin{array}{l}\text { ITS or } \\
\text { ITWI }\end{array}$ & $\begin{array}{l}\text { Safety } \\
\text { Category }\end{array}$ & Nuclear Safety Design Bases \\
\hline $\begin{array}{l}\text { Cask Transfer } \\
\text { (continued) }\end{array}$ & $\begin{array}{l}\text { Site-Specific } \\
\text { Transfer Cask }\end{array}$ & ITS & SC & $\begin{array}{l}\text { - The design of the site-specific transfer cask shall ensure that it can withstand a drop in } \\
\text { the worst orientation from the combined maximum handling height and allowable speed of } \\
\text { a horizontal cask transfer trailer without loss of function. (BSC 2005b Section 5.1.11.1) } \\
\text { - The design of the site-specific transfer cask shall ensure that it can withstand extreme } \\
\text { temperatures without breach. (BSC } 2005 \mathrm{~b} \text { Section 5.1.11.9) } \\
\text { - Site-specific transfer casks shall be designed for extreme straight wind. (BSC 2005b } \\
\text { Section 4.1.13, BSC 2005h Section 9; and BSC 2005f Sections 6.1.1.2) } \\
\text { - The site-specific transfer cask shall be designed to ensure nuclear criticality safety with } \\
\text { optimum moderation and the most reactive waste forms. Criticality safety will be } \\
\text { maintained despite geometric rearrangements due to a drop or other handling incidents. } \\
\text { (BSC 2005b Section 5.1.1.4) }\end{array}$ \\
\hline Aging Pad & $\begin{array}{l}\text { Surface Aging } \\
\text { Pad }\end{array}$ & ITS & SC & 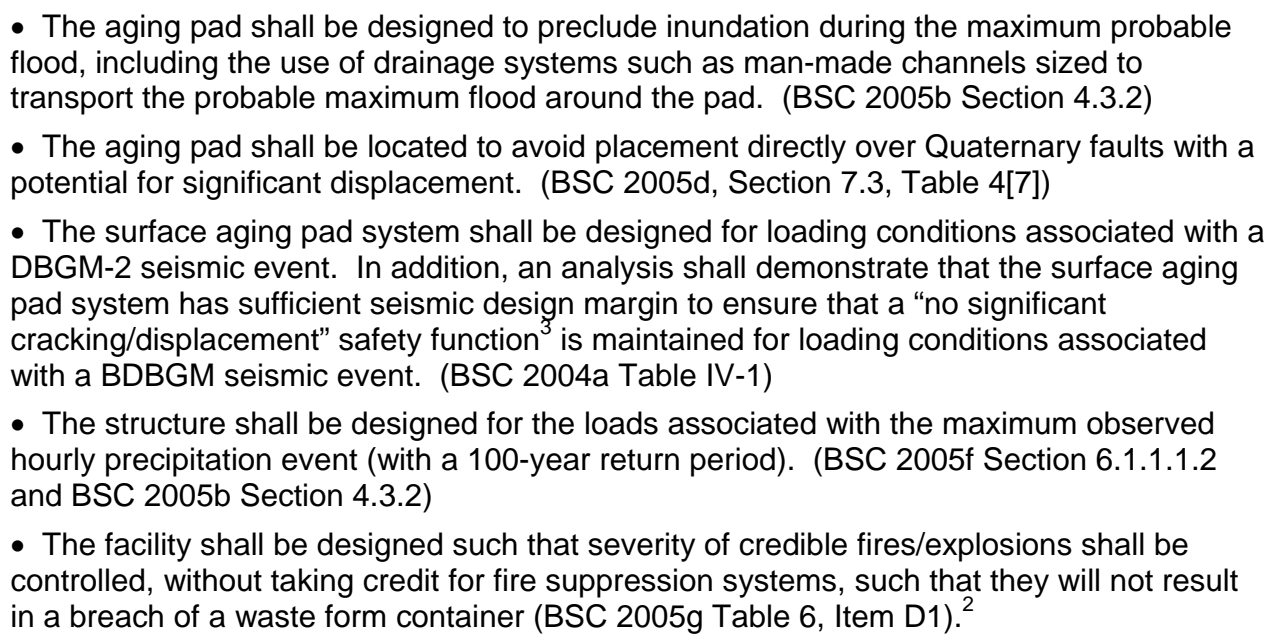 \\
\hline
\end{tabular}




\begin{tabular}{|c|c|c|c|c|}
\hline $\begin{array}{l}\text { System or } \\
\text { Subsystem }\end{array}$ & $\begin{array}{l}\text { Component } \\
\text { or Function }\end{array}$ & $\begin{array}{l}\text { ITS or } \\
\text { ITWI }\end{array}$ & $\begin{array}{l}\text { Safety } \\
\text { Category }\end{array}$ & Nuclear Safety Design Bases \\
\hline $\begin{array}{l}\text { Aging Pad } \\
\text { (continued) }\end{array}$ & $\begin{array}{l}\text { Support } \\
\text { Structures } \\
\text { (including Utility } \\
\text { Buildings and } \\
\text { Personnel } \\
\text { Barriers) }\end{array}$ & N/A & Non-SC & $\begin{array}{l}\text { Not applicable. None of the SSC functions associated with these subsystems are credited } \\
\text { for the prevention or mitigation of an event sequence. }\end{array}$ \\
\hline \multirow[t]{2}{*}{ Aging Cask } & $\begin{array}{l}\text { Site-Specific } \\
\text { Canister }\end{array}$ & ITS & SC & $\begin{array}{l}\text { - The site-specific canister shall be designed to ensure nuclear criticality safety with } \\
\text { optimum moderation and the most reactive waste forms. Criticality safety will be } \\
\text { maintained despite geometric rearrangements due to a drop or other handling incidents. } \\
\text { (BSC 2005b Section 5.1.1.4) }\end{array}$ \\
\hline & $\begin{array}{l}\text { Site-Specific } \\
\text { Canister Internal } \\
\text { Geometry and } \\
\text { Neutron } \\
\text { Absorbers }\end{array}$ & $\begin{array}{l}\text { ITS and } \\
\text { ITWI }\end{array}$ & SC & $\begin{array}{l}\text { - The site-specific canister internal geometry control shall be capable of meeting loading } \\
\text { conditions associated with a DBGM-2 seismic event and to demonstrate sufficient seismic } \\
\text { design margin to ensure that a "no criticality" safety function }{ }^{3} \text { is maintained for loading } \\
\text { conditions associated with a BDBGM seismic event. (BSC 2004a Table IV-1) }\end{array}$ \\
\hline
\end{tabular}




\begin{tabular}{|c|c|c|c|c|}
\hline $\begin{array}{l}\text { System or } \\
\text { Subsystem }\end{array}$ & $\begin{array}{l}\text { Component } \\
\text { or Function }\end{array}$ & $\begin{array}{l}\text { ITS or } \\
\text { ITWI }\end{array}$ & $\begin{array}{c}\text { Safety } \\
\text { Category }\end{array}$ & Nuclear Safety Design Bases \\
\hline $\begin{array}{l}\text { Aging Cask } \\
\text { (continued) }\end{array}$ & Site-Specific Cask & ITS & SC & 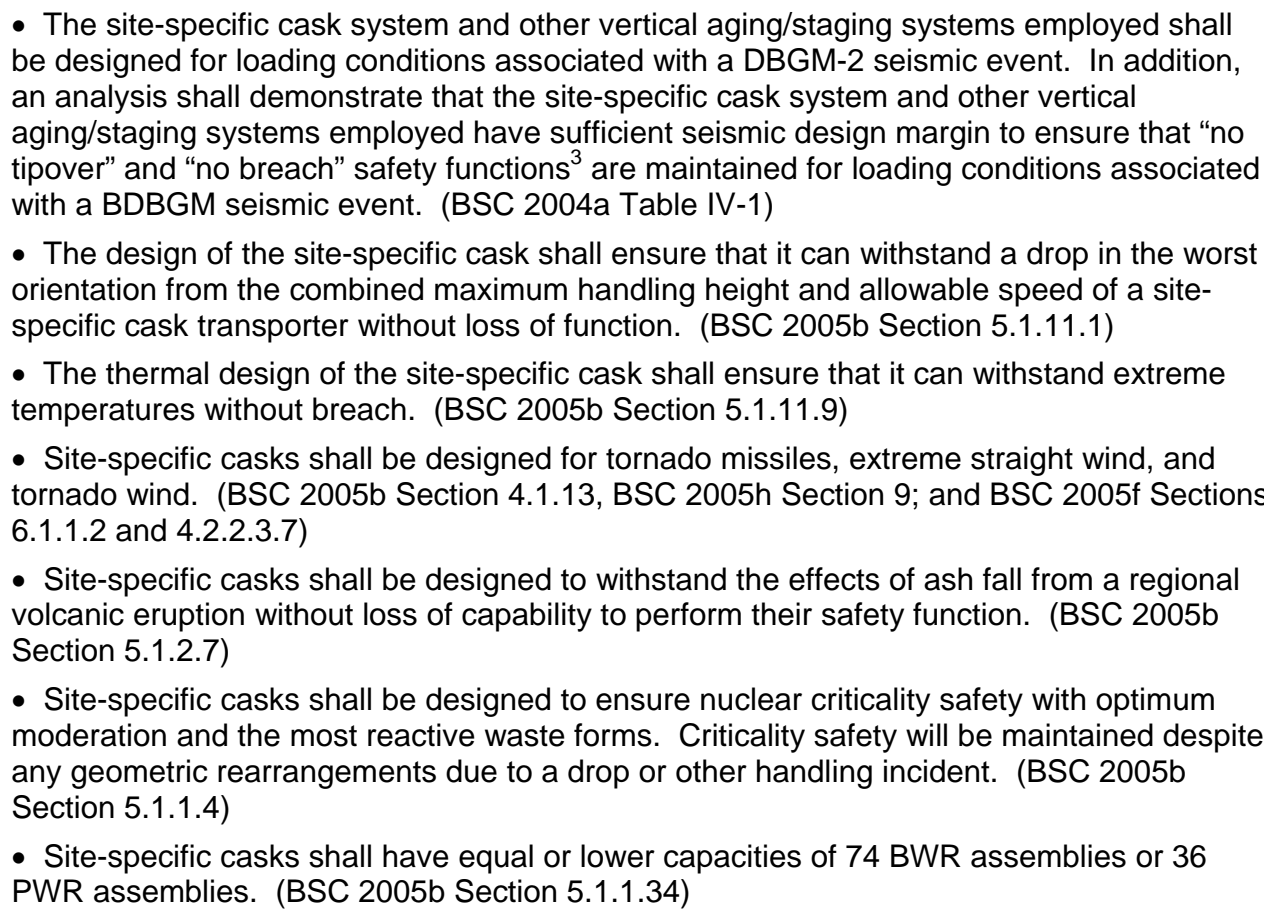 \\
\hline
\end{tabular}




\begin{tabular}{|c|c|c|c|c|}
\hline $\begin{array}{l}\text { System or } \\
\text { Subsystem }\end{array}$ & $\begin{array}{l}\text { Component } \\
\text { or Function }\end{array}$ & $\begin{array}{l}\text { ITS or } \\
\text { ITWI }\end{array}$ & $\begin{array}{l}\text { Safety } \\
\text { Category }\end{array}$ & Nuclear Safety Design Bases \\
\hline $\begin{array}{l}\text { Aging Cask } \\
\text { (continued) }\end{array}$ & $\begin{array}{l}\text { Horizontal Aging } \\
\text { Module }\end{array}$ & ITS & SC & $\begin{array}{l}\text { - HAMs shall be designed for loading conditions associated with a DBGM-2 seismic event } \\
\text { In addition, an analysis shall demonstrate that the HAMs have sufficient seismic design } \\
\text { margin to ensure that a "no collapse" safety function is is maintained for loading conditions } \\
\text { associated with a BDBGM seismic event. (BSC 2004a Table IV-1) } \\
\text { - Stationary structures such as the HAMs shall be designed for tornado missiles, extreme } \\
\text { straight wind, and tornado wind. (BSC 2005b Section 4.1.13, BSC 2005h Section } 9 \text {, and } \\
\text { BSC } 2005 f \text { Sections } 6.1 .1 .2 \text { and } 4.2 .2 .3 .7 \text { ) } \\
\text { - The thermal design of the HAM shall ensure that it can withstand extreme temperatures } \\
\text { without breach. (BSC 2005b Section 5.1.11.9) } \\
\text { - Surface facilities, including the HAMS, shall be designed to withstand the effects of ash } \\
\text { fall from a regional volcanic eruption without loss of capability to perform their safety } \\
\text { functions. (BSC 2005b Section 5.1.2.7 and BSC 2005f Section 4.2.2.3.4) } \\
\text { - The facility shall be designed such that severity of credible fires/explosions shall be } \\
\text { controlled, without taking credit for fire suppression systems, so that they will not result in a } \\
\text { breach of a waste form container'. (BSC 2005g Table 6, Item D1) } \\
\text { - The structure shall be designed for the loads associated with the maximum observed } \\
\text { hourly precipitation event (with a 100-year return period). (BSC 2005f Section 6.1.1.1.2 } \\
\text { and BSC 2005b Section 4.3.2) }\end{array}$ \\
\hline
\end{tabular}


- The lift height limits for the sealed and unsealed, loaded WPs handled by this crane are provided in Table C-1 in Appendix C. These WPs include:

1. Unsealed, loaded WPs containing commercial SNF, standardized DOE SNF canisters, DOE HLW canisters, naval SNF canisters, or DOE MCOs.

2. Sealed WPs containing commercial SNF, standardized DOE SNF canisters, DOE HLW canisters, naval SNF canisters, or DOE MCOs.

- This crane system shall be designed for loading conditions associated with a DBGM-2 seismic event and maintain its load. In addition, an analysis shall demonstrate that this crane system has sufficient seismic design margin to ensure that a "no drop" safety function $^{3}$ is maintained for loading conditions associated with a BDBGM seismic event. (BSC 2004a Table IV-1)

- This crane shall not be capable of moving above a speed limit for overhead crane transfers such that a collision at the speed limit would not breach a loaded, sealed WP. (BSC 2005b Section 5.1.1.19)

- This crane shall not be capable of exerting sufficient force to breach a WP as the result of attempts to overcome mechanical constraints. (BSC 2005b Section 5.1.1.20) 


\begin{tabular}{|c|c|c|c|c|}
\hline $\begin{array}{l}\text { System or } \\
\text { Subsystem }\end{array}$ & $\begin{array}{l}\text { Component } \\
\text { or Function }\end{array}$ & $\begin{array}{l}\text { ITS or } \\
\text { ITWI }\end{array}$ & $\begin{array}{l}\text { Safety } \\
\text { Category }\end{array}$ & Nuclear Safety Design Bases \\
\hline \multirow[t]{2}{*}{$\begin{array}{l}\text { WP Loadout } \\
\text { (continued) }\end{array}$} & $\begin{array}{l}\text { WP Handling } \\
\text { Crane (DTF, } \\
\text { Room 1044); } 100 \\
\text { ton (continued) }\end{array}$ & ITS & $\mathrm{sC}$ & $\begin{array}{l}\text { - The severity of credible fires/explosions in areas where the waste forms are present } \\
\text { shall not cause the handling equipment that handles SNF/HLW to drop its load. (BSC } \\
2005 \mathrm{~g} \text { Table } 6 \text {, Item I1) } \\
\text { - Cranes and other machinery that handle SNF/HLW shall be designed to minimize the } \\
\text { probability of occurrence of uncontrolled movements resulting from a loss of power or from } \\
\text { spurious signals initiated by a credible fire/explosion, such as to render a potential event } \\
\text { sequence Beyond Category 2. (BSC } 2005 \mathrm{~g} \text { Table 6, Item I3) }\end{array}$ \\
\hline & $\begin{array}{l}\text { WP Loadout } \\
\text { Handling Crane } \\
\text { (DTF Room } \\
\text { 1088); } 100 \text { ton }\end{array}$ & ITS & sc & $\begin{array}{l}\text { - The drop rate for cranes involved in handling waste forms and their associated } \\
\text { containers shall be less than or equal to } 1 \times 10^{-5} \text { drops/transfer, regardless of cause, } \\
\text { including human error, failure of equipment such as yokes and grapples, or a combination } \\
\text { of the two. (BSC 2005b Section 5.1.1.10) } \\
\text { - Upon a loss of power, this crane shall be designed to stop, retain its load, and enter a } \\
\text { locked mode; upon a restoration of power, this crane shall stay in the locked mode until } \\
\text { operator action is taken. (BSC } 2005 \mathrm{~b} \text { Section } 5.1 .2 .1 \text { ) } \\
\text { - The conditional probability of the crane exceeding a lift-height limit, given that a drop has } \\
\text { occurred, shall be less than or equal to } 1 \times 10^{-4} \text {. (BSC 2005b Section 5.1.1.12) } \\
\text { - This crane system shall be designed for loading conditions associated with a DBGM-2 } \\
\text { seismic event and maintain its load. In addition, an analysis shall demonstrate that the } \\
\text { crane system has sufficient seismic design margin to ensure that a "no drop" safety } \\
\text { function is maintained for loading conditions associated with a BDBGM seismic event. } \\
\text { (BSC } 2004 \text { a Table IV-1) } \\
\text { - The lift height limits for the sealed WPs handled by this crane are provided in Table C-1 } \\
\text { in Appendix C. These WPs include sealed WPs containing commercial SNF, standardized } \\
\text { DOE SNF canisters, DOE HLW canisters, naval SNF canisters, or DOE MCOs. } \\
\text { - This crane shall not be capable of moving above a speed limit for overhead crane } \\
\text { transfers such that a collision at the speed limit would not breach a loaded, sealed WP. } \\
\text { (BSC } 2005 \mathrm{~b} \text { Section 5.1.1.19) }\end{array}$ \\
\hline
\end{tabular}




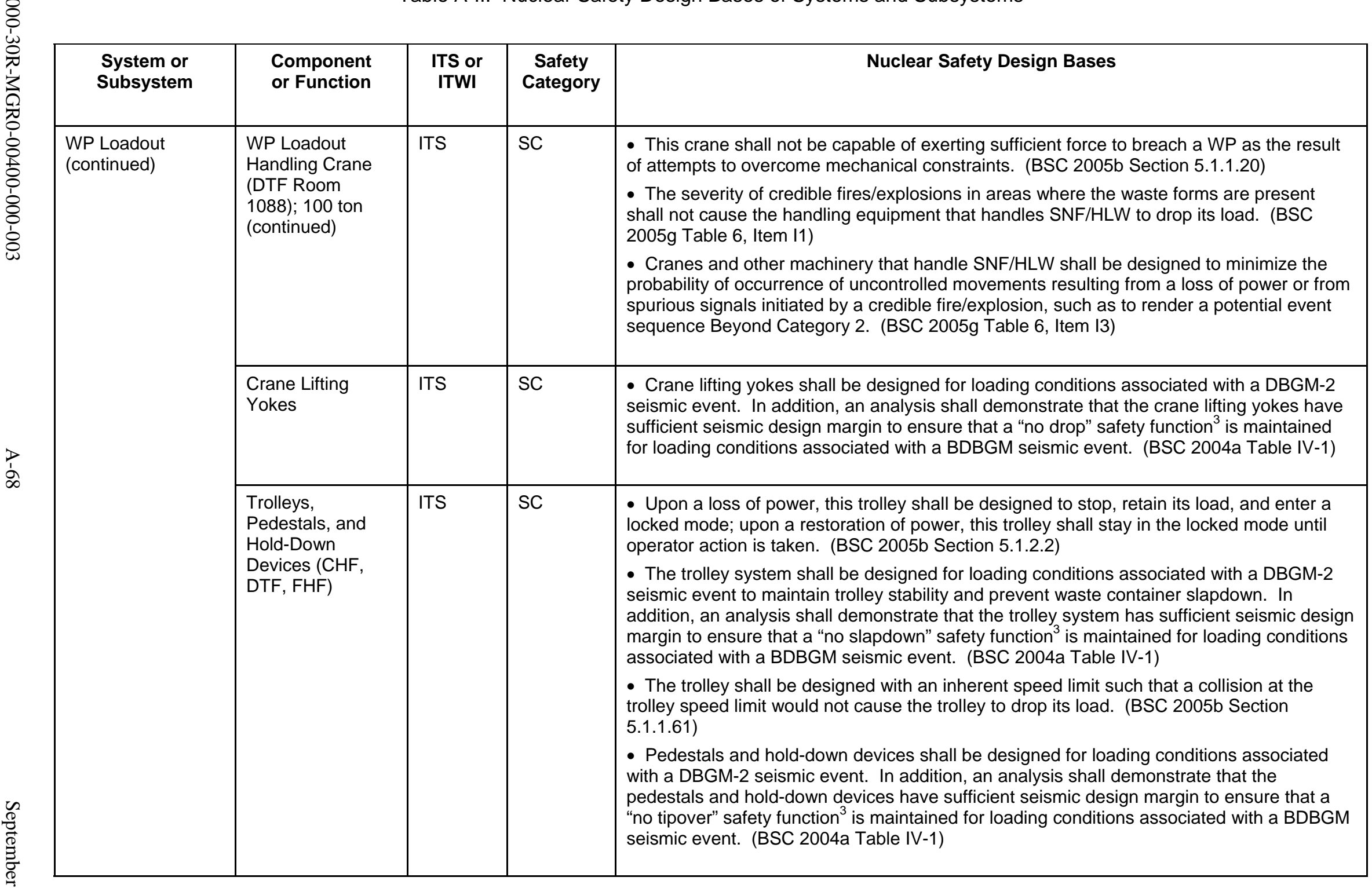




\begin{tabular}{|c|c|c|c|c|}
\hline $\begin{array}{l}\text { System or } \\
\text { Subsystem }\end{array}$ & $\begin{array}{l}\text { Component } \\
\text { or Function }\end{array}$ & $\begin{array}{l}\text { ITS or } \\
\text { ITWI }\end{array}$ & $\begin{array}{l}\text { Safety } \\
\text { Category }\end{array}$ & Nuclear Safety Design Bases \\
\hline \multirow[t]{2}{*}{$\begin{array}{l}\text { WP Loadout } \\
\text { (continued) }\end{array}$} & $\begin{array}{l}\text { Trolleys, } \\
\text { Pedestals, and } \\
\text { Hold-Down } \\
\text { Devices (CHF, } \\
\text { DTF, FHF) } \\
\text { (continued) }\end{array}$ & ITS & SC & $\begin{array}{l}\text { - Loaded transfer trolleys shall not derail or drop their loads. (BSC 2005b Section } \\
\text { 5.1.1.36) } \\
\text { - The severity of credible fires/explosions in areas where the waste forms are present } \\
\text { shall not cause the handling equipment that handles SNF/HLW to drop its load. (BSC } \\
2005 \mathrm{~g} \text { Table } 6 \text {, Item I1) } \\
\text { - Machinery that handles SNF/HLW shall be designed to minimize the probability of } \\
\text { occurrence of uncontrolled movements resulting from a loss of power or from spurious } \\
\text { signals initiated by a credible fire/explosion, such as to render a potential event sequence } \\
\text { Beyond Category 2. (BSC } 2005 \mathrm{~g} \text { Table } 6 \text {, Item I3) }\end{array}$ \\
\hline & $\begin{array}{l}\text { WP Tilting } \\
\text { Machine (DTF, } \\
\text { CHF, FHF) }\end{array}$ & ITS & SC & $\begin{array}{l}\text { - The WP tilting machine system shall be designed for loading conditions associated with } \\
\text { a DBGM-2 seismic event to maintain stability and prevent a WP drop or slapdown. In } \\
\text { addition, an analysis shall demonstrate that the WP tilting machine system has sufficient } \\
\text { seismic design margin to ensure that "no drop" and "no slapdown" safety functions }{ }^{3} \text { are } \\
\text { maintained for loading conditions associated with a BDBGM seismic event. (BSC 2004a } \\
\text { Table IV-1) } \\
\text { - The WP tilting machine shall be designed to prevent backward slapdowns. (BSC 2005b } \\
\text { Section 5.1.1.53) } \\
\text { - The WP tilting machine shall include measures to prevent movement or release of the } \\
\text { lock on WP trunnions while the WP is being lowered onto the emplacement pallet. (BSC } \\
2005 \mathrm{~b} \text { Section 5.1.1.53) } \\
\text { - An impact or collision between the WP tilting machine and a WP shall not breach the } \\
\text { WP or cause it to fall off the emplacement pallet. (BSC } 2005 \mathrm{~b} \text { Section 5.1.3.10) } \\
\text { - The severity of credible fires/explosions in areas where the waste forms are present } \\
\text { shall not cause the handling equipment that handles SNF/HLW to drop its load. (BSC } \\
2005 \mathrm{~g} \text { Table } 6 \text {, Item I1) } \\
\text { - Cranes and other machinery that handle SNF/HLW shall be designed to minimize the } \\
\text { probability of occurrence of uncontrolled movements resulting from a loss of power or from } \\
\text { spurious signals initiated by a credible fire/explosion, such as to render a potential event } \\
\text { sequence Beyond Category 2. (BSC } 2005 g \text { Table } 6 \text {, Item I3) }\end{array}$ \\
\hline
\end{tabular}




\begin{tabular}{|c|c|c|c|c|}
\hline $\begin{array}{l}\text { System or } \\
\text { Subsystem }\end{array}$ & $\begin{array}{l}\text { Component } \\
\text { or Function }\end{array}$ & $\begin{array}{l}\text { ITS or } \\
\text { ITWI }\end{array}$ & $\begin{array}{l}\text { Safety } \\
\text { Category }\end{array}$ & Nuclear Safety Design Bases \\
\hline \multirow[t]{2}{*}{$\begin{array}{l}\text { WP Loadout } \\
\text { (continued) }\end{array}$} & $\begin{array}{l}\text { WP Turntable } \\
\text { (DTF, CHF, FHF) }\end{array}$ & ITS & SC & $\begin{array}{l}\text { - The WP turntable system shall be designed for loading conditions associated with a } \\
\text { DBGM-2 seismic event to maintain turntable stability and prevent WP tipover. In addition, } \\
\text { an analysis shall demonstrate that the WP turntable system has sufficient seismic design } \\
\text { margin to ensure that a "no tipover" safety function }{ }^{3} \text { is maintained for loading conditions } \\
\text { associated with a BDBGM seismic event. (BSC } 2004 a \text { Table IV-1) } \\
\text { - The premature actuation of the WP turntable (while holding the WP on an emplacement } \\
\text { pallet) before the disengagement of the trunnion collar removal machine shall be } \\
\text { precluded. (BSC 2005b Section 5.1.1.16) } \\
\text { - An impact or collision between the WP turntable and a WP shall not breach the WP or } \\
\text { cause it to fall off the emplacement pallet. (BSC } 2005 \mathrm{~b} \text { Section } 5.1 .3 .10 \text { ) } \\
\text { - The severity of credible fires/explosions in areas where the waste forms are present } \\
\text { shall not cause the handling equipment that handles SNF/HLW to drop its load. (BSC } \\
2005 \mathrm{~g} \text { Table } 6 \text {, Item I1) } \\
\text { - Cranes and other machinery that handle SNF/HLW shall be designed to minimize the } \\
\text { probability of occurrence of uncontrolled movements resulting from a loss of power or from } \\
\text { spurious signals initiated by a credible fire/explosion, such as to render a potential event } \\
\text { sequence Beyond Category 2. (BSC } 2005 \mathrm{~T} \text { Table } 6 \text {, Item I3) }\end{array}$ \\
\hline & $\begin{array}{l}\text { Trunnion Collar } \\
\text { Removal Machine } \\
\text { (DTF, CHF, FHF) }\end{array}$ & ITS & SC & $\begin{array}{l}\text { - The trunnion collar removal machine system shall be designed for loading conditions } \\
\text { associated with a DBGM-2 seismic event to prevent slapdown of the WP. In addition, an } \\
\text { analysis shall demonstrate that the trunnion collar removal machine system has sufficient } \\
\text { seismic design margin to ensure that "no slapdown" and "no breach" safety functions }{ }^{3} \text { are } \\
\text { maintained for loading conditions associated with a BDBGM seismic event. (BSC 2004a } \\
\text { Table IV-1) } \\
\text { - The premature actuation of the WP turntable (while holding the WP on an emplacement } \\
\text { pallet) before the disengagement of the trunnion collar removal machine shall be } \\
\text { precluded. (BSC 2005b Section 5.1.1.16) } \\
\text { - An impact or collision between the trunnion collar removal machine and a WP shall not } \\
\text { breach the WP or cause it to fall off the emplacement pallet. (BSC 2005b Section 5.1.3.10) }\end{array}$ \\
\hline
\end{tabular}




\begin{tabular}{|c|c|c|c|c|}
\hline $\begin{array}{l}\text { System or } \\
\text { Subsystem }\end{array}$ & $\begin{array}{l}\text { Component } \\
\text { or Function }\end{array}$ & $\begin{array}{l}\text { ITS or } \\
\text { ITWI }\end{array}$ & $\begin{array}{l}\text { Safety } \\
\text { Category }\end{array}$ & Nuclear Safety Design Bases \\
\hline DPC Cutting & $\begin{array}{l}\text { DPC Cutting } \\
\text { Machine (DTF) }\end{array}$ & ITS & SC & 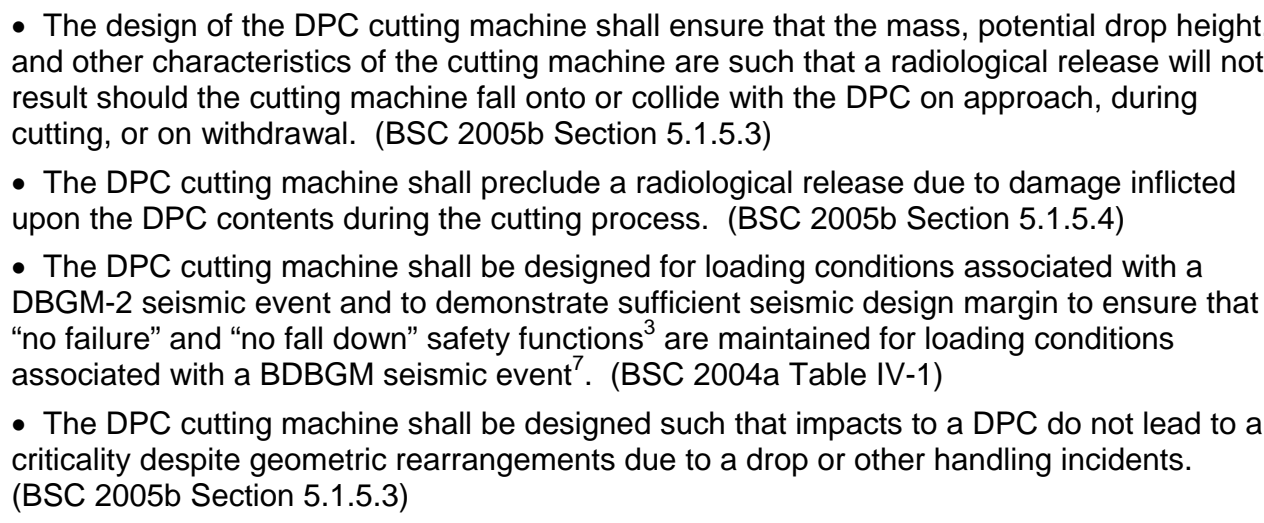 \\
\hline & $\begin{array}{l}\text { DPC Docking } \\
\text { Station }\end{array}$ & ITS & SC & $\begin{array}{l}\text { - A drop or collision involving components associated with a docking port shall not breach } \\
\text { the lid of a transportation cask or site-specific cask situated at the docking port. (BSC } \\
\text { 2005b Section 5.1.1.17) }\end{array}$ \\
\hline
\end{tabular}




\begin{tabular}{|c|c|c|c|c|}
\hline $\begin{array}{l}\text { System or } \\
\text { Subsystem }\end{array}$ & $\begin{array}{l}\text { Component } \\
\text { or Function }\end{array}$ & $\begin{array}{l}\text { ITS or } \\
\text { ITWI }\end{array}$ & $\begin{array}{l}\text { Safety } \\
\text { Category }\end{array}$ & Nuclear Safety Design Bases \\
\hline $\begin{array}{l}\text { Dry Transfer } \\
\text { (continued) }\end{array}$ & $\begin{array}{l}\text { Naval Canister } \\
\text { Handling Crane } \\
\text { (DTF); } 70 \text { ton }\end{array}$ & ITS & SC & $\begin{array}{l}\text { - The drop rate for cranes involved in handling waste forms and their associated } \\
\text { containers shall be less than or equal to } 1 \times 10^{-5} \text { drops/transfer, regardless of cause, } \\
\text { including human error, failure of equipment such as yokes and grapples, or a combination } \\
\text { of the two. (BSC } 2005 \text { b Section } 5.1 .1 .10 \text { ) } \\
\text { - Upon a loss of power, this crane shall be designed to stop, retain its load, and enter a } \\
\text { locked mode; upon a restoration of power, this crane shall stay in the locked mode until } \\
\text { operator action is taken. (BSC } 2005 b \text { Section } 5.1 .2 .1 \text { ) } \\
\text { - The conditional probability of the crane exceeding a lift-height limit, given that a drop has } \\
\text { occurred, shall be less than or equal to } 1 \times 10^{-4} \text {. (BSC } 2005 \mathrm{~b} \text { Section } 5.1 .1 .12 \text { ) } \\
\text { - The lift height limits for the naval SNF canisters handled by this crane are provided in } \\
\text { Table C-1 in Appendix C. } \\
\text { - This crane system shall be designed for loading conditions associated with a DBGM-2 } \\
\text { seismic event and maintain its load. In addition, an analysis shall demonstrate that this } \\
\text { crane system has sufficient seismic design margin to ensure that a "no drop" safety } \\
\text { function is maintained for loading conditions associated with a BDBGM seismic event. } \\
\text { (BSC } 2004 a \text { Table IV-1) } \\
\text { - This crane shall not be capable of moving above a speed limit for overhead crane } \\
\text { transfers such that a collision at the speed limit would not breach a naval SNF canister. } \\
\text { (BSC } 2005 b \text { Section } 5.1 .1 .19 \text { ) } \\
\text { - The severity of credible fires/explosions in areas where the waste forms are present } \\
\text { shall not cause the handling equipment that handles SNF/HLW to drop its load. (BSC } \\
2005 g \text { Table } 6 \text {, Item I1) } \\
\text { - Cranes and other machinery that handle SNF/HLW shall be designed to minimize the } \\
\text { probability of occurrence of uncontrolled movements resulting from a loss of power or from } \\
\text { spurious signals initiated by a credible fire/explosion, such as to render a potential event } \\
\text { sequence Beyond Category } 2 \text {. (BSC } 2005 g \text { Table } 6 \text {, Item I3) } \\
\text { - This crane shall not be capable of exerting sufficient force to breach a canister as the } \\
\text { result of attempts to overcome mechanical constraints. (BSC } 2005 b \text { Section } 5.1 .1 .20 \text { ) }\end{array}$ \\
\hline
\end{tabular}




\begin{tabular}{|c|c|c|c|c|}
\hline $\begin{array}{l}\text { System or } \\
\text { Subsystem }\end{array}$ & $\begin{array}{l}\text { Component } \\
\text { or Function }\end{array}$ & $\begin{array}{l}\text { ITS or } \\
\text { ITWI }\end{array}$ & $\begin{array}{l}\text { Safety } \\
\text { Category }\end{array}$ & Nuclear Safety Design Bases \\
\hline $\begin{array}{l}\text { Dry Transfer } \\
\text { (continued) }\end{array}$ & $\begin{array}{l}\text { Crane Lifting } \\
\text { Yokes }\end{array}$ & ITS & SC & $\begin{array}{l}\text { - The crane lifting yokes shall be designed for loading conditions associated with a } \\
\text { DBGM-2 seismic event. In addition, an analysis shall demonstrate that the crane lifting } \\
\text { yokes have sufficient seismic design margin to ensure that a "no drop" safety function is } \\
\text { maintained for loading conditions associated with a BDBGM seismic event. (BSC 2004a } \\
\text { Table IV-1) }\end{array}$ \\
\hline & $\begin{array}{l}\text { Cask/WP Docking } \\
\text { Station (DTF, } \\
\text { FHF) }\end{array}$ & ITS & SC & $\begin{array}{l}\text { - A drop or collision involving components associated with a docking port shall not breach } \\
\text { the lid of a transportation cask or site-specific cask situated at the docking port. (BSC } \\
\text { 2005b Section 5.1.1.17) }\end{array}$ \\
\hline & $\begin{array}{l}\text { Canister and SNF } \\
\text { Staging Racks } \\
\text { (DTF) }\end{array}$ & ITS & SC & $\begin{array}{l}\text { - The canister and SNF staging racks shall be designed such that criticality safety is } \\
\text { ensured for the commercial SNF assembly staging racks loaded to capacity with the most } \\
\text { reactive commercial SNF assembly accepted at the repository with moderator control in } \\
\text { effect. (BSC 2005b Section 5.1.4.2) } \\
\text { - The canister and SNF staging racks shall be designed such that criticality safety is } \\
\text { ensured for commercial SNF assemblies dropped into or onto a commercial SNF assembly } \\
\text { staging rack with moderator control in effect. (BSC 2005b Section 5.1.4.3) } \\
\text { - The canister and SNF staging racks shall be designed such that the most reactive } \\
\text { configuration of standardized DOE SNF canisters is capable of being loaded into the } \\
\text { canister staging racks (with credit for moderator control) without leading to a nuclear } \\
\text { criticality. (BSC 2005b Section 5.1.1.2) } \\
\text { - The canister and SNF staging tubes shall be designed for loading conditions associated } \\
\text { with a DBGM-2 seismic event for stability and distortion such as to maintain } \\
\text { assembly/canister geometry in the rack. In addition, analyses shall demonstrate that the } \\
\text { staging tubes have sufficient seismic design margin to ensure that distortion of the tubes is } \\
\text { limited and stability is maintained for loading conditions associated with a BDBGM seismic } \\
\text { event. (BSC 2004a Table IV-1) } \\
\text { - The spacing between the surfaces of DOE SNF canisters in a staging array must be } \\
30 \mathrm{~cm} \text { or greater. (BSC 2005b Section 5.1.1.3) } \\
\text { - The commercial SNF staging racks in the DTF shall withstand, without degradation of } \\
\text { their confinement function, the drop of a commercial SNF assembly in the rack from the } \\
\text { spent fuel transfer machine. (BSC } 2005 \mathrm{~b} \text { Section 5.1.4.5) }\end{array}$ \\
\hline
\end{tabular}


Subsurface Ventilation System

\begin{tabular}{|l|l|l|l|l}
\hline $\begin{array}{l}\text { Subsurface } \\
\text { Ventilation }\end{array}$ & Entire & N/A & Non-SC & $\begin{array}{l}\text { Not applicable. None of the SSC functions associated with these subsystems are credited } \\
\text { for the prevention or mitigation of an event sequence. }\end{array}$ \\
\hline
\end{tabular}

Surface Industrial HVAC System

\begin{tabular}{|c|c|c|c|c|}
\hline $\begin{array}{l}\text { Surface Industrial } \\
\text { HVAC }\end{array}$ & $\begin{array}{l}\text { Inlet and Outlet } \\
\text { Dampers and } \\
\text { Ventilation } \\
\text { Ducting (including } \\
\text { stack) for Fuel } \\
\text { Element Staging } \\
\text { Areas (DTF) }\end{array}$ & ITS & SC & $\begin{array}{l}\text { - The inlet and outlet dampers and ventilation ducting for the fuel element staging areas } \\
\text { shall be designed for loading conditions associated with a DBGM-1 seismic event to } \\
\text { ensure that a "no failure" safety function }{ }^{3} \text { is maintained. (BSC 2004a Table IV-1) } \\
\text { - The ventilation stack for the fuel element staging areas (DTF only) shall be designed for } \\
\text { loading conditions associated with a DBGM-1 seismic event to ensure that a "controlled } \\
\text { failure" safety function }{ }^{3} \text { is maintained. (BSC 2004a Table IV-1) } \\
\text { - A loss of HVAC for up to } 30 \text { days in areas where SNF or HLW is handled or staged shall } \\
\text { not cause waste form temperatures to exceed allowable limits. } \\
\text { (BSC 2005b Section }\end{array}$ \\
\hline
\end{tabular}


Table A-II. Nuclear Safety Design Bases of Systems and Subsystems

\begin{tabular}{|c|c|c|c|c|}
\hline $\begin{array}{l}\text { System or } \\
\text { Subsystem }\end{array}$ & $\begin{array}{l}\text { Component } \\
\text { or Function }\end{array}$ & $\begin{array}{l}\text { ITS or } \\
\text { ITWI }\end{array}$ & $\begin{array}{l}\text { Safety } \\
\text { Category }\end{array}$ & Nuclear Safety Design Bases \\
\hline \multicolumn{5}{|c|}{ Surface Nuclear HVAC System } \\
\hline $\begin{array}{l}\text { Primary } \\
\text { Confinement }\end{array}$ & Entire (DTF, FHF) & ITS & $\mathrm{SC}$ & $\begin{array}{l}\text { - To mitigate the worker and public doses following a Category } 1 \text { event sequence, the } \\
\text { Surface Nuclear HVAC system shall be equipped with HEPA filters. A two-stage HEPA } \\
\text { filtration system with a particulate removal efficiency of at least 99\% per stage is required. } \\
\text { This requirement applies to the DTF and the FHF. (BSC 2005c Section 4.1.1) } \\
\text { - The HEPA filters and vent ducts (exhaust ducting and dampers) shall be designed for } \\
\text { loading conditions associated with a DBGM-1 seismic event to ensure that a "no } \\
\text { discharge" safety function }{ }^{3} \text { is maintained. (BSC } 2004 \text { a Table IV-1) } \\
\text { - The probability that the HVAC system, including HEPA filtration in the primary } \\
\text { confinement areas of the DTF and FHF, becomes unavailable during a 4-hour mission time } \\
\text { shall be } 0.01 \text { or less, without credit for backup electrical power. (BSC 2005b Section } \\
5.1 .1 .48 \text { ) } \\
\text { - A loss of HVAC for up to } 30 \text { days in areas where SNF or HLW is handled or staged shall } \\
\text { not cause waste form temperatures to exceed allowable limits. (BSC 2005b Section } \\
5.1 .2 .4 \text { ) } \\
\text { - HEPA filters shall continue to provide their required particulate removal efficiency when } \\
\text { exposed to embers and hot gas layer temperatures resulting from a fire in the DTF or FHF } \\
\text { (BSC 2005b Section 5.1.1.62) } \\
\text { - The surface nuclear HVAC system shall be capable of performing its 4-hr mission of } \\
\text { radiological release mitigation in the situation where primary confinement has been lost } \\
\text { due to a drop of a commercial SNF assembly onto a docking ring. (BSC } 2005 \mathrm{~b} \text { Section } \\
5.1 .1 .63 \text { ) }\end{array}$ \\
\hline
\end{tabular}




\begin{tabular}{|c|c|c|c|c|}
\hline $\begin{array}{l}\text { System or } \\
\text { Subsystem }\end{array}$ & $\begin{array}{l}\text { Component } \\
\text { or Function }\end{array}$ & $\begin{array}{l}\text { ITS or } \\
\text { ITWI }\end{array}$ & $\begin{array}{l}\text { Safety } \\
\text { Category }\end{array}$ & Nuclear Safety Design Bases \\
\hline $\begin{array}{l}\text { Secondary } \\
\text { Confinement }\end{array}$ & Entire & N/A & Non-SC & $\begin{array}{l}\text { Not applicable. None of the SSC functions associated with these subsystems are credited } \\
\text { for the prevention or mitigation of an event sequence. }\end{array}$ \\
\hline $\begin{array}{l}\text { Tertiary } \\
\text { Confinement }\end{array}$ & Entire & $N / A$ & Non-SC & $\begin{array}{l}\text { Not applicable. None of the SSC functions associated with these subsystems are credited } \\
\text { for the prevention or mitigation of an event sequence. }\end{array}$ \\
\hline \multicolumn{5}{|r|}{ Transportation Cask } \\
\hline $\begin{array}{l}\text { Transportation } \\
\text { Cask }\end{array}$ & Entire & ITS & SC & $\begin{array}{l}\text { Transportation casks provide adequate protection against external hazards on the } \\
\text { repository site. See footnotes } 1 \text { and } 4 \text {. }\end{array}$ \\
\hline \multicolumn{5}{|r|}{ WP Closure System } \\
\hline $\begin{array}{l}\text { Welding } \\
\text { (Equipment) }\end{array}$ & Entire & N/A & Non-SC & $\begin{array}{l}\text { Not applicable. None of the SSC functions associated with these subsystems are credited } \\
\text { for the prevention or mitigation of an event sequence. }\end{array}$ \\
\hline $\begin{array}{l}\text { Inerting } \\
\text { (Equipment) }\end{array}$ & Entire & N/A & Non-SC & $\begin{array}{l}\text { Not applicable. None of the SSC functions associated with these subsystems are credited } \\
\text { for the prevention or mitigation of an event sequence. }\end{array}$ \\
\hline $\begin{array}{l}\text { Non-Destructive } \\
\text { Testing } \\
\text { (Equipment) }\end{array}$ & Entire & $\mathrm{N} / \mathrm{A}$ & Non-SC & $\begin{array}{l}\text { Not applicable. None of the SSC functions associated with these subsystems are credited } \\
\text { for the prevention or mitigation of an event sequence. }\end{array}$ \\
\hline $\begin{array}{l}\text { Stress Mitigation } \\
\text { (Equipment) }\end{array}$ & Entire & N/A & Non-SC & $\begin{array}{l}\text { Not applicable. None of the SSC functions associated with these subsystems are credited } \\
\text { for the prevention or mitigation of an event sequence. }\end{array}$ \\
\hline WP Identification & Entire & N/A & Non-SC & $\begin{array}{l}\text { Not applicable. None of the SSC functions associated with these subsystems are credited } \\
\text { for the prevention or mitigation of an event sequence. }\end{array}$ \\
\hline $\begin{array}{l}\text { Spread Ring } \\
\text { Installation }\end{array}$ & Entire & N/A & Non-SC & $\begin{array}{l}\text { Not applicable. None of the SSC functions associated with these subsystems are credited } \\
\text { for the prevention or mitigation of an event sequence. }\end{array}$ \\
\hline
\end{tabular}


Table A-II. Nuclear Safety Design Bases of Systems and Subsystems

\begin{tabular}{|l|l|l|l|l|}
\hline \multicolumn{1}{|c|}{$\begin{array}{c}\text { System or } \\
\text { Subsystem }\end{array}$} & $\begin{array}{c}\text { Component } \\
\text { or Function }\end{array}$ & $\begin{array}{c}\text { ITS or } \\
\text { ITWI }\end{array}$ & $\begin{array}{c}\text { Safety } \\
\text { Category }\end{array}$ & \multicolumn{1}{|c|}{ Nuclear Safety Design Bases } \\
\hline Material Handling & Entire & N/A & Non-SC & $\begin{array}{l}\text { Not applicable. None of the SSC functions associated with these subsystems are credited } \\
\text { for the prevention or mitigation of an event sequence. }\end{array}$ \\
\hline $\begin{array}{l}\text { Remote Equipment } \\
\text { Maintenance }\end{array}$ & Entire & N/A & Non-SC & $\begin{array}{l}\text { Not applicable. None of the SSC functions associated with these subsystems are credited } \\
\text { for the prevention or mitigation of an event sequence. }\end{array}$ \\
\hline Operations Control & Entire & N/A & Non-SC & $\begin{array}{l}\text { Not applicable. None of the SSC functions associated with these subsystems are credited } \\
\text { for the prevention or mitigation of an event sequence. }\end{array}$ \\
\hline
\end{tabular}

FOOTNOTES (Applicable to both Table A-I and Table A-II):

1. Functions of the transportation casks are credited to prevent or mitigate event sequences. The certification process for transportation casks under 10 CFR Part 71 [DIRS 173375] considers severe transportation accident conditions and conditions of normal transport. The precedent that licensed casks provide adequate protection against all hazards that apply during the transportation phase establishes the basis that the casks will continue to provide adequate protection at the repository site.

2. This requirement applies to the following types of waste form containers, as needed, to avoid a radioactive release: transportation casks, transfer casks, DOE MCOs, DOE standardized canisters, naval SFCs, DOE HLW canisters, DPCs, site-specific canisters, aging casks, and waste packages (BSC 2005g [DIRS 174263], Table 6, Item D1). The naval SNF canister will not be exposed to fire conditions more severe than those corresponding to a black body gas exposure flux of $50 \mathrm{~kW} / \mathrm{m}^{2}$ and a temperature of $1000^{\circ} \mathrm{C}\left(1832^{\circ} \mathrm{F}\right)$ for 2 minutes (BSC 2005g [DIRS 174263], Section 6.2.1.2.6).

3. The definitions of the Safety Functions are provided in Appendix B.

4. Transportation casks must meet the flame emissivity and cask absorptivity requirements of 10 CFR 71.73(c)(4).

5. Not used.

6. Analyses will confirm that sealed WPs shall withstand drops onto energy-absorbing crush pads without breaching and that the impact consequences associated with a drop of a canister or cask onto energy-absorbing crush pads shall be equal to, or less than, the impact consequences associated with the drop of a cask or canister from the maximum specified drop height onto an unyielding surface.

7. The seismic requirements for the WP cutting machine and DPC cutting machine are specified in Seismic Analysis for Preclosure Safety (BSC 2004a) for the cutting machine listed in Table IV-1

\section{GENERAL NOTES:}

Lift height limits can be exceeded provided that energy-absorbing material is used to limit the impact energy to that of the drop height limit.

The load drop probability includes components (lifting yokes, trunnions, and grapples) associated with the lifting and transferring of heavy loads. 
The trolley system includes the trolley, rails, pedestal, and control system.

The term cask refers to both the transportation cask and the site-specific cask, unless specified otherwise.

Every facility may not use every component listed for each system.

The term breach means an opening of the cask, canister, or WP initiating a Category 1 or Category 2 event sequence.

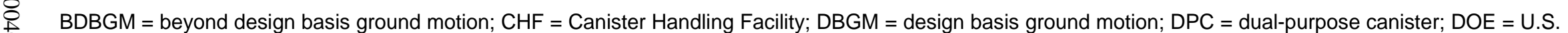

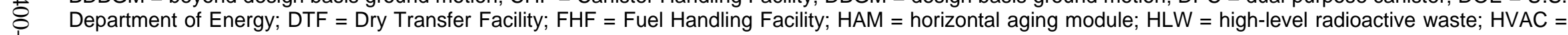

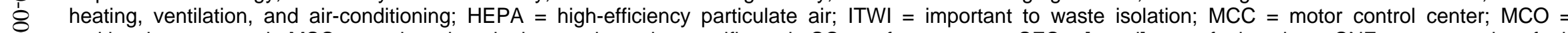

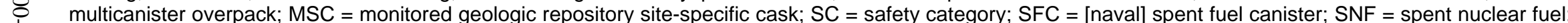

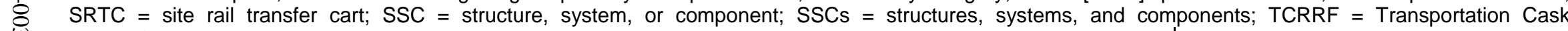
Receipt/Return Facility; UPS = uninterruptable power supply; WNNRF = Warehouse and Non-Nuclear Receipt Facility; WP = waste package. 


\section{APPENDIX B}

\section{B.1 General}

\section{DEFINITION OF SAFETY FUNCTIONS}

Each SSC that is ITS that is credited in the prevention or mitigation of a seismically initiated event sequence is assigned a safety function (or functions) with regard to performance goals for the specific SSC during and after the initiating seismic event. This appendix defines the safety functions used in this report. These definitions of safety functions were obtained from Seismic Analysis for Preclosure Safety (BSC 2004a [DIRS 171470], Section 4).

\section{B.1.1 Safety Function: No Structural Collapse}

The "no structural collapse" safety function is assigned to facilities and structures assigned to either a DBGM-1 or DBGM-2 level. For seismic margin calculations, the function corresponds approximately to the state of "large permanent distortion, short of collapse" of a structure or facility, termed Limit State A.

The "no structural collapse" safety function has the following performance goals during and after a seismic event:

- $\quad$ No structural collapse occurs (i.e., column and support members remain upright, beams remain functional, and walls remain standing), and failure of the contents is not serious enough to cause severe injury or death, prevent evacuation, or induce a breach of a waste container.

- Confinement of internal airflow is not required and may not be maintained. Concrete walls will remain standing, but may be extensively cracked; they may not maintain pressure differential with normal HVAC. Cracks will still provide a tortuous path for material release. The largest cracks are expected to be no greater than one-half inch.

- $\quad$ Distortion of the structure will be limited, but expected to be visible to the naked eye.

- Components will remain anchored, but with no assurance that they will remain functional or easily repairable.

An additional requirement of this safety function is that the failure of adjacent structures and other SSCs (whether ITS or not) shall be considered in seismic analyses, as appropriate, and shall not induce collapse of the designated structure.

\section{B.1.2 Safety Function: No Drop}

The "no drop" safety function is assigned to cranes assigned to a DBGM-2 level. The no-drop safety function has the following performance goals during and after a seismic event: 
- $\quad$ The crane shall not release (or drop) a waste container or waste form either due to failure of crane components or controls due to a designated seismic event.

- $\quad$ The crane, as a system, shall not collapse or fall down. The crane shall remain on its track or guide system (regardless if crane is holding a waste container or waste form at the time of the event).

- Horizontal movement (swinging) of the cask or WP shall be restrained (if necessary) to preclude impacts with nearby walls and barriers.

- $\quad$ The crane track or guide system shall remain intact and attached to the structure. It may be distorted and bent, however.

- $\quad$ The crane shall not move in an uncontrolled manner or exceed its design speed limit.

\section{B.1.3 Safety Function: No Breach}

The "no breach" safety function is assigned to various waste containers assigned to either a DBGM-1 or DBGM-2 level.

The no breach (leak tight) safety function has the following performance goals during and after a seismic event:

- $\quad$ Containment of the waste form is maintained and no release or dispersement of radionuclides (either as gas or particulates) to the environment occurs.

- $\quad$ Distortion and damage of the container will be limited.

\section{B.1.4 Safety Function: No Tipover}

The "no tipover" safety function is assigned to various SSCs handling casks and canisters (e.g., turntables and pedestals) assigned to either a DBGM-1 or DBGM-2 level. The no tipover safety function has the following performance goal during and after a seismic event:

- $\quad$ The SSC shall not allow a tipover of a cask or canister (i.e., an overturn from an upright or normal position and impact the floor, ground, or other object), or tilting of the cask or canister resulting in an impact with an adjacent SCC that is ITS causing a domino effect.

\section{B.1.5 Safety Function: No Slapdown}

The "no slapdown" safety function is assigned to various SSCs handling casks and canisters (e.g., trolleys, WP transporters, transport locomotives, horizontal aging modules, site-specific cask transporters) assigned to either a DBGM-1 or DBGM-2 level. The no slapdown safety function has the following performance goals during and after a seismic event: 
- $\quad$ The SSC shall not allow a slapdown or rapid drop of a cask or WP in transit (i.e., the fall of a cask or WP, a vertical distance and subsequent impact onto the floor, ground, or onto another object).

- Any impacts to the cask or WP shall be within design specifications and, thereby, not induce a breach of the cask or WP in transit.

- $\quad$ The SSC itself may sustain substantial damage and may no longer be operable.

\section{B.1.6 Safety Function: No Release}

The "no release" safety function is assigned to staging and storage racks assigned to either a DBGM-1 or DBGM-2 level.

The no release safety function has the following performance goals during and after a seismic event:

- $\quad$ No release or dispersement of radionuclides (either as gas and/or as particulates) to the environment due to shaking or deformation of the waste form or storage rack.

- $\quad$ Distortion and damage of the waste form and rack(s) will be limited and will not preclude additional operations to retrieve the waste forms.

\section{B.1.7 Safety Function: No Failure}

The "no failure" safety function is assigned to various SSCs (e.g., limiters, collars, dampers) assigned to either a DBGM-1 or DBGM-2 level. The no failure safety function has the following performance goal during and after a seismic event:

- $\quad$ The SSC will continue its designated safety function after a seismic event without significant degradation in the performance. For structural elements, the load | response shall be essentially elastic due to the seismic event.

\section{B.1.8 Safety Function: No Significant Cracking/Displacement}

The "no significant cracking/displacement" safety function is assigned to aging pads at the DBGM-2 level. The no significant cracking/displacement safety function has the following performance goals during and after a seismic event:

- $\quad$ Aging pad is essentially intact. The concrete will remain structurally sound, but may contain several small cracks. The largest cracks are expected to be no greater than one-eighth inch and lengths shorter than 2 feet.

- $\quad$ Distortion of the pad will be very limited and not expected to be immediately apparent to the naked eye.

- Differential displacement across the pad shall be minimal, with differential displacements insufficient to cause a tipover of individual storage casks. 


\section{B.1.9 Safety Function: Controlled Failure}

The "controlled failure" safety function is assigned in special instances to SSCs (e.g., ventilation stacks) to preclude potential interactions with SSCs that are ITS. The controlled failure safety function has the following performance goals for ventilation stacks during and after a seismic event:

- $\quad$ Failure of an SSC due to a seismic event shall not obstruct an open flow path to the environment of the corresponding ventilation system.

- $\quad$ Failure of an SSC shall not impede the safety function of another SSC that is ITS.

\section{B.1.10 Safety Function: Shielding Integrity Remains Intact}

The "shielding integrity remains intact" safety function is assigned to shielding SSCs (e.g., shield view ports, shield windows, shield doors) at the DBGM-1 and DBGM-2 levels. The shielding integrity remains intact safety function has the following performance goals during and after a seismic event:

- $\quad$ The SSC remains essentially intact and in-place, and provides sufficient (direct shine) shielding to permit workers to egress the area without receiving a significant dose ("significant" is defined as less than 10 percent of the worker dose limit).

- $\quad$ Cracking of glass will be limited, and drainage of fluids (used in ports and windows for shielding) will be slow.

\section{B.1.11 Safety Function: Maintain Waste Form}

The "maintain waste form" safety function is assigned to fuel handling machines at either the DBGM-1 or DBGM-2 level. The maintain waste form safety function has the following performance goals during and after a seismic event:

- $\quad$ The SSC continues to maintain (retain) the waste form.

- $\quad$ The waste form remains intact and in-place.

- $\quad$ Damage to the waste form is minimal.

- $\quad$ Significant release or dispersement of radionuclides (either as gas and/or as particulates) to the environment due to shaking or deformation of the waste form is precluded. 


\section{B.1.12 Safety Function: No Criticality}

The "no criticality" safety function is assigned to various waste containers (e.g., casks, canisters, WPs) and staging and storage racks assigned to DBGM-2 level.

For various waste containers, the no criticality safety function has the following performance goals during and after a seismic event:

- The waste in the container shall remain subcritical as a result of a drop or impact within design limits with the most reactive credible configuration of the fissile material and moderation to the most reactive credible extent.

- $\quad$ The container internal geometry shall retain the design waste configuration with only minor damage/distortion.

For staging and storage racks, the no criticality safety function has the following performance goal during and after a seismic event:

- $\quad$ The rack shall remain structurally intact (with minimal distortion of the rack) and prevent bare fuel assemblies (or other exposed waste forms) from becoming critical as a result, considering the most reactive credible configuration of the fissile material and moderation to the most reactive credible extent.

\section{B.1.13 Safety Function: No Runaway}

The "no runaway" (uncontrolled descent) safety function is assigned to transporters and locomotives assigned to the DBGM-1 and DBGM-2 levels. The no runaway safety function has the following performance goals during and after a seismic event:

- $\quad$ The SSC shall stop the transport train (the trailer/car containing a waste form) after a seismic event (however, a tipover is not precluded).

- $\quad$ The SSC shall not allow the speed of the transport train to exceed its maximum allowable limits.

- $\quad$ The coupler shall remain connected between the locomotive and transport train.

\section{B.1.14 Safety Function: No Discharge}

The "no discharge" safety function is assigned to SSCs such as vent ducts, as well as HEPA filters and filter housings, which can contain a significant particulate dose and are assigned to either a DBGM-1 or DBGM-2 level.

For filters, the no discharge safety function has the following performance goals during and after a seismic event:

- No significant release or dispersement of radionuclides (particulates) to the immediate environment (to the structure interior or exterior) due to shaking of the 
filter and/or deformation of the filter (housing) system occurs. A significant release is defined as a release that results in less than a small fraction of the applicable dose limit over a period of 24 hours.

- No significant release or dispersement of radionuclides (particulates) back into the interior ventilation system (i.e., no back flow); this shall be precluded by valves/dampers or other appropriate devices.

- External components of the system (e.g., housings and fans) shall be rigidly anchored to major building elements (walls, floors, partitions).

- The system shall maintain its structural integrity, and distortion/damage of the housing and hangers (if applicable) will be limited.

For vent ducts, the no discharge safety function has the following performance goals during and after a seismic event:

- No significant release or dispersement of radionuclides (particulates) to the immediate environment. A significant release is defined as a release that results in less than a small fraction of the applicable dose limit over a period of 24 hours, and analyses shall consider potential accumulations within the duct re-entering the air stream.

- The duct shall maintain effective confinement of internal airflow with minimal outflow through joints.

- The duct shall maintain its structural integrity, and distortion/damage of the duct and hangers will be limited.

\section{B.1.15 Safety Function: No Derailment}

The "no derailment" safety function is assigned to trolley rails and rail tracks, which are assigned to either a DBGM-1 or DBGM-2 level.

The no derailment safety function has the following performance goals during and after a seismic event:

- $\quad$ No significant structural deformation of the rail occurs (i.e., the rails will not shear, heave, or warp) that is serious enough to cause a derailment or tipover of any waste transporter on the rail (e.g., WP trolley).

- $\quad$ No significant failure of the rail occurs (e.g., shearing, separation) that could induce a derailment if a transporter would pass over the damaged section.

- Distortion of the rail will be limited and not expected to be immediately apparent to the naked eye. 
- The rail will remain, for the most part, anchored and functional (or easily repairable).

- $\quad$ The rail system shall not impede the braking of any waste transporter on the rail.

\section{B.1.16 Safety Function: No Fall Down}

The "no fall down" safety function is assigned to large equipment (spent fuel handling machines, welders) that could impact SSCs if the specific equipment loses its anchorage and falls due to a seismic event. These SSCs can be assigned to either a DBGM-1 or DBGM-2 level.

The no fall down safety function has the following performance goals during and after a seismic event:

- $\quad$ The equipment, as a system, shall not collapse or fall down. The equipment shall remain on its track/guide system (if present).

- $\quad$ Anchorage for the equipment shall maintain the equipment in-place.

\section{B.1.17 Safety Function: No Loss of Confinement}

The "no loss of confinement" safety function is assigned to facilities and structures assigned to either a DBGM-1 or DBGM-2 level where structural integrity and confinement after the seismic event must be credited for compliance or added for defense-in-depth. For seismic margin calculations, the function corresponds to the state of limited permanent distortion of a structure or facility, termed Limit State C.

In the present dose consequence analysis, no credit is taken for confinement for limiting offsite dose to the public and, thereby, this safety function is not used. This definition was added for completeness.

The no loss of confinement safety function has the following performance goals during and after a seismic event:

- $\quad$ No structural collapse occurs (i.e., column and support members remain upright, beams remain functional, and walls remain standing), and failure of contents is not serious enough to cause severe injury or death, prevent evacuation, or induce a breach of a waste container.

- $\quad$ Confinement of internal airflow is required and will be maintained. Concrete walls will remain standing, but may be cracked. This cracking however, is small enough to maintain the pressure differential with normal HVAC. The largest cracks are expected to be no greater than approximately one-eighth in.

- $\quad$ Distortion of the structure will be very limited and not expected to be immediately apparent to the naked eye.

- $\quad$ Components will remain anchored and functional or easily repairable. 
An additional requirement of this safety function is that the failure of adjacent structures and other SSCs (whether safety-related or not) shall be considered in seismic analyses as appropriate and shall not induce collapse of the designated structure. 


\section{APPENDIX C}

\section{LIFT HEIGHT LIMITS FOR WASTE FORMS}

The various casks, canisters, SNF assemblies, and WPs to be handled in the repository surface facilities shall be lifted by the various cranes in these facilities in accordance with the limits specified in Table C-1. The rationale for the establishment of each of these limits is provided in the stated reference, which describes in detail why each limit is required and what limitations and assumptions are applicable.

Table C-I. Lift Height Limits

\begin{tabular}{|c|c|c|c|}
\hline Confinement & Contents & Lift Height Limit(s) (Note 1) & Reference \\
\hline $\begin{array}{l}\text { Transportation cask } \\
\text { with impact limiters }\end{array}$ & Any waste form & $\begin{array}{l}30 \mathrm{ft} \text { in the worst orientation above an } \\
\text { essentially unyielding flat surface }\end{array}$ & $\begin{array}{c}\text { BSC 2005b Sections 4.2.1, } \\
5.1 .9 .1\end{array}$ \\
\hline \multirow[t]{3}{*}{$\begin{array}{l}\text { Transportation cask } \\
\text { without impact } \\
\text { limiters }\end{array}$} & DOE MCO & $\begin{array}{c}2 \mathrm{ft} \text { in any orientation above an essentially } \\
\text { unyielding flat surface unless impact } \\
\text { absorption feature is credited }\end{array}$ & BSC 2005b Section 5.1.1.18 \\
\hline & Naval SNF Canister & $\begin{array}{l}16 \mathrm{ft} \text { in any orientation above an } \\
\text { essentially unyielding flat surface }\end{array}$ & BSC 2005b Section 5.1.1.18 \\
\hline & Any other waste form & $\begin{array}{l}23 \mathrm{ft} \text { in any orientation above an } \\
\text { essentially unyielding flat surface }\end{array}$ & BSC 2005b Section 5.1.1.18 \\
\hline Transfer Casks & DPC & $\begin{array}{c}23 \mathrm{ft} \text { in vertical orientation from the floor } \\
\text { of the transportation cask or } \\
\text { site-specific cask } \\
\text { and } \\
2 \mathrm{ft} \text { in vertical orientation above the floor } \\
\text { of the transfer cell }\end{array}$ & BSC 2005b Section 5.1.1.43 \\
\hline Site-specific cask & $\begin{array}{c}\text { Commercial SNF. } \\
\text { DPC, Site-Specific } \\
\text { Canister, } \\
\text { Standardized DOE } \\
\text { SNF Canisters, or } \\
\text { DOE HLW Canisters }\end{array}$ & $\begin{array}{l}23 \mathrm{ft} \text { in any orientation above an } \\
\text { essentially unyielding flat surface }\end{array}$ & BSC 2005b Section 5.1.1.18 \\
\hline \multirow[t]{2}{*}{ Unconfined } & DPC & $\begin{array}{c}23 \mathrm{ft} \text { in vertical orientation from the floor } \\
\text { of the transportation cask, transfer } \\
\text { cask, or site-specific cask } \\
\text { and } \\
2 \mathrm{ft} \text { in vertical orientation above the floor } \\
\text { of the transfer cell }\end{array}$ & BSC 2005b Section 5.1.1.43 \\
\hline & $\begin{array}{l}\text { Site-Specific } \\
\text { Canister }\end{array}$ & $\begin{array}{l}23 \mathrm{ft} \text { in vertical orientation from the floor } \\
\text { of the WP or site-specific cask } \\
\text { and } \\
2 \mathrm{ft} \text { in vertical orientation above the floor } \\
\text { of the transfer cell }\end{array}$ & BSC 2005b Section 5.1.1.43 \\
\hline
\end{tabular}


Table C-I. Lift Height Limits (continued)

\begin{tabular}{|c|c|c|c|}
\hline Confinement & Contents & Lift Height Limit(s) (Note 1) & Reference \\
\hline \multirow[t]{5}{*}{$\begin{array}{l}\text { Unconfined } \\
\text { (continued) }\end{array}$} & $\begin{array}{l}\text { Commercial SNF } \\
\text { Assembly }\end{array}$ & $\begin{array}{c}28 \mathrm{ft} \text { above an essentially unyielding } \\
\text { surface }\end{array}$ & $\begin{array}{c}\text { BSC 2005b Section } \\
5.1 .1 .46\end{array}$ \\
\hline & $\begin{array}{l}\text { Standardized DOE } \\
\text { SNF Canister }\end{array}$ & $\begin{array}{c}23 \mathrm{ft} \text { in an approximately vertical } \\
\text { orientation above the floor of a cask, WP, } \\
\text { staging rack, or staging pit } \\
\text { and } \\
2 \mathrm{ft} \text { above the floor of the transfer cell } \\
\text { (any orientation) }\end{array}$ & BSC 2005b Section 5.1.1.14 \\
\hline & DOE MCO & $\begin{array}{c}23 \mathrm{ft} \text { in vertical orientation (within } 3 \\
\text { degrees of vertical orientation) onto an } \\
\text { essentially flat unyielding surface (floor of } \\
\text { a cask or WP) } \\
\text { and } \\
2 \mathrm{ft} \text { in any orientation above an essentially } \\
\text { unyielding flat surface (floor of transfer } \\
\text { cell) }\end{array}$ & BSC 2005b Section 5.1.1.15 \\
\hline & DOE HLW Canister & $\begin{array}{c}23 \mathrm{ft} \text { in vertical orientation above the floor } \\
\text { of a cask, WP, staging rack or staging } \text { pit }^{2} \\
\text { and } \\
2 \mathrm{ft} \text { above the floor of the transfer cell }\end{array}$ & BSC 2005b Section 5.1.1.24 \\
\hline & Naval SNF Canister & $\begin{array}{c}28 \mathrm{ft} \text { in vertical orientation above the floor } \\
\text { of a cask or WP } \\
\text { and } \\
2 \mathrm{ft} \text { above the floor of the transfer cell } \\
\text { where the orientation is not considered to } \\
\text { be vertical }\end{array}$ & BSC 2005b Section 5.1.1.42 \\
\hline \multirow[t]{2}{*}{$\begin{array}{l}\text { Waste package } \\
\text { (sealed; trunnion } \\
\text { collars installed) }\end{array}$} & $\begin{array}{l}\text { Naval Long SNF } \\
\text { Canister }\end{array}$ & $\begin{array}{c}3.3 \mathrm{ft} \text { in vertical orientation onto an } \\
\text { essentially unyielding flat surface } \\
\text { and } \\
1.6 \mathrm{ft} \text { for tipover from an elevated surface } \\
\text { onto an essentially unyielding flat surface }\end{array}$ & $\begin{array}{c}\text { BSC 2005b Sections 5.1.3.12 } \\
\text { and 5.1.3.9 }\end{array}$ \\
\hline & Any waste form & $\begin{array}{l}7.8 \mathrm{ft} \text { in a horizontal orientation onto an } \\
\text { essentially unyielding flat surface } \\
\text { and } \\
6.5 \mathrm{ft} \text { in a vertical orientation over an } \\
\text { essentially unyielding flat surface (except } \\
\text { naval long WP) as measured from the } \\
\text { bottom of the WP } \\
\text { and } \\
6.5 \mathrm{ft} \text { for tipover from an elevated surface } \\
\text { onto an essentially unyielding flat surface } \\
\text { (except naval long WP) }\end{array}$ & $\begin{array}{c}\text { BSC 2005b Sections 5.1.3.12 } \\
\text { and 5.1.3.9 }\end{array}$ \\
\hline
\end{tabular}


Table C-I. Lift Height Limits (continued)

\begin{tabular}{|c|c|c|c|}
\hline Confinement & Contents & Lift Height Limit(s) (Note 1) & Reference \\
\hline Waste package & Any waste form & $\begin{array}{l}6.5 \mathrm{ft} \text { from bottom of the pallet to an } \\
\text { essentially unyielding flat surface, in a } \\
\text { horizontal orientation }\end{array}$ & $\begin{array}{c}\text { BSC 2005b Sections 5.1.3.8 } \\
\text { and 5.1.3.12 }\end{array}$ \\
\hline \multirow[t]{5}{*}{$\begin{array}{l}\text { Waste package } \\
\text { (unsealed) }\end{array}$} & $\begin{array}{l}\text { DOE MCO / DOE } \\
\text { HLW Canister }\end{array}$ & $\begin{array}{c}2 \mathrm{ft} \text { above an essentially unyielding flat } \\
\text { surface for drops in which the WP may } \\
\text { topple and overturn or slap down } \\
\text { and } \\
23 \mathrm{ft} \text { for flat-bottom drops (axis of the } \\
\text { canister is } 3 \text { degrees of vertical) above an } \\
\text { essentially unyielding flat surface (e.g., in } \\
\text { a WP loading pit) such that the WP } \\
\text { remains upright }\end{array}$ & BSC 2005b Section 5.1.1.52 \\
\hline & Commercial SNF & $\begin{array}{l}2 \mathrm{ft} \text { above an essentially unyielding flat } \\
\text { surface for drops in which the WP may } \\
\text { topple and overturn or slap down } \\
\text { and } \\
28 \mathrm{ft} \text { for flat-bottom drops above an } \\
\text { essentially unyielding flat surface (e.g., in } \\
\text { a WP loading pit) such that the WP } \\
\text { remains upright } \\
\end{array}$ & BSC 2005b Section 5.1.1.52 \\
\hline & Naval SNF Canister & $\begin{array}{l}2 \mathrm{ft} \text { above an essentially unyielding flat } \\
\text { surface for drops in which the WP may } \\
\text { topple and overturn or slap down } \\
\quad \text { and } \\
16 \mathrm{ft} \text { for a flat-bottom drop onto an } \\
\text { essentially unyielding surface (e.g., in a } \\
\text { WP loading pit) where the WP remains } \\
\text { upright }\end{array}$ & BSC 2005b Section 5.1.1.52 \\
\hline & $\begin{array}{l}\text { Site-Specific } \\
\text { Canister }\end{array}$ & $\begin{array}{c}23 \mathrm{ft} \text { in vertical orientation from the floor } \\
\text { of the WP or site-specific cask } \\
\text { and } \\
2 \mathrm{ft} \text { in vertical orientation above the floor } \\
\text { of the transfer cell }\end{array}$ & BSC 2005b Section 5.1.1.43 \\
\hline & $\begin{array}{l}\text { DOE HLW Canister / } \\
\text { DOE SNF Canister }\end{array}$ & $\begin{array}{l}23 \mathrm{ft} \text { for flat-bottom drops above an } \\
\text { essentially unyielding flat surface (e.g., in } \\
\text { a WP loading pit) such that the WP } \\
\text { remains upright } \\
\text { and } \\
2 \mathrm{ft} \text { above an essentially unyielding flat } \\
\text { surface for drops in which the WP may } \\
\text { topple and overturn or slap down }\end{array}$ & BSC 2005b Section 5.1.1.52 \\
\hline
\end{tabular}

Note 1: These lift height limits can be exceeded if an appropriate impact absorption feature is credited.

Note 2: A breach of the wasteform is assumed if the wasteform is dropped from higher than the stated lift height. 


\section{INTENTIONALLY LEFT BLANK}

